\title{
Best practice for motor imagery: a systematic literature review on motor imagery training elements in five different disciplines
}

Corina Schuster ${ }^{1,2}$, Roger Hilfiker ${ }^{3}$, Oliver Amft ${ }^{4,5^{*}}$, Anne Scheidhauer ${ }^{1}$, Brian Andrews ${ }^{6,7}$, Jenny Butler ${ }^{2}$, Udo Kischka ${ }^{1,8}$ and Thierry Ettlin ${ }^{1,9}$

\begin{abstract}
Background: The literature suggests a beneficial effect of motor imagery (MI) if combined with physical practice, but detailed descriptions of Ml training session (MITS) elements and temporal parameters are lacking. The aim of this review was to identify the characteristics of a successful MITS and compare these for different disciplines, MI session types, task focus, age, gender and Ml modification during intervention.

Methods: An extended systematic literature search using 24 databases was performed for five disciplines: Education, Medicine, Music, Psychology and Sports. References that described an Ml intervention that focused on motor skills, performance or strength improvement were included. Information describing 17 MITS elements was extracted based on the PETTLEP (physical, environment, timing, task, learning, emotion, perspective) approach. Seven elements describing the MITS temporal parameters were calculated: study duration, intervention duration, MITS duration, total MITS count, MITS per week, MI trials per MITS and total MI training time.

Results: Both independent reviewers found $96 \%$ congruity, which was tested on a random sample of $20 \%$ of all references. After selection, 133 studies reporting $141 \mathrm{MI}$ interventions were included. The locations of the MITS and position of the participants during MI were task-specific. Participants received acoustic detailed MI instructions, which were mostly standardised and live. During Ml practice, participants kept their eyes closed. MI training was performed from an internal perspective with a kinaesthetic mode. Changes in MI content, duration and dosage were reported in $31 \mathrm{Ml}$ interventions. Familiarisation sessions before the start of the $\mathrm{Ml}$ intervention were mentioned in 17 reports. MI interventions focused with decreasing relevance on motor-, cognitive- and strengthfocused tasks. Average study intervention lasted 34 days, with participants practicing MI on average three times per week for 17 minutes, with $34 \mathrm{Ml}$ trials. Average total MI time was 178 minutes including 13 MITS. Reporting rate varied between $25.5 \%$ and $95.5 \%$.
\end{abstract}

Conclusions: MITS elements of successful interventions were individual, supervised and non-directed sessions, added after physical practice. Successful design characteristics were dominant in the Psychology literature, in interventions focusing on motor and strength-related tasks, in interventions with participants aged 20 to 29 years old, and in Ml interventions including participants of both genders. Systematic searching of the Ml literature was constrained by the lack of a defined MeSH term.

\footnotetext{
* Correspondence: oliver.amft@gmail.com

${ }^{4}$ Faculty of Electrical Engineering, Technical University Eindhoven, Eindhoven,

The Netherlands

Full list of author information is available at the end of the article
} 


\section{Introduction}

In sports psychology, there is evidence that mental practice (MP) can accelerate learning and improve motor skills. In their extensive meta-analysis in 1983, Feltz and Landers included single-group interventions with preand post-tests (tests before and after the interventions), and studies with multiple groups to compare an MP group versus controls [1]. They summarised 60 studies regardless of their quality and methods. Analysis of effect sizes showed that performing MP is not as good as physical practice (PP) but is better than doing no practice at all. In their revised meta-analysis in 1988, they replicated the previous results [2].

MP can be considered an umbrella term that includes various mental training interventions. In recent years, researchers have started to use the term 'motor imagery' (MI) to specifically address the imagination of moving specific body parts.

Over the past two decades, the publication of MP literature has increased tremendously, from 122 publications up to 1980 to a total of 20,011 publications in 2009 (PubMed search on 12 April 2010 with the search term 'mental practice'). The MI technique has been adopted in other research areas (education, medicine, music and sports), where the beneficial effect of MI added to PP has been confirmed, and 27 reviews summarise the research findings in those fields [1-27]. Despite the different review foci (for example, history and development of MI, theoretical concepts of MI functioning and effectiveness evaluation), all reviews attribute a beneficial effect to MI when added to PP. In some reviews, the methodological procedure lacked a systematic approach.

\section{Aim of the current systematic literature review}

None of the published reviews have analysed the design of the MI training session (MITS) to determine successful MI intervention techniques, such as the position of the person during MI, the number of MI trials, and the instruction mode and type. However, the MITS design is of vital importance for researchers and clinicians planning to implement MI interventions adapted to participant health status, age and gender. In this systematic literature review, we extracted and analysed 17 MITS elements based on the PETTLEP (physical, environment, timing, task, learning, emotion, perspective) approach. Furthermore, we analysed seven temporal parameters, including duration times and number of repetitions. In total, we analysed five disciplines in which MI represents an important training strategy.

\section{Imagery models and frameworks in the education and psychology literature}

Hall described the cognitive processes and neural basis of $\mathrm{MI}$ in a review on educational literature, based on a
MEDLINE search [7]., and proposed a six-stage procedure for explicit learning of surgical skills: task definition, prior learning, mental rehearsal, reflection, problem solving and reality check.

In psychology, various tasks, participant groups and reporting statistics have been considered for MI. Driskell et al. summarised the effects of MP and determined under which conditions MI was most effective [13]. They defined five conditions of interest: 1) type of task, 2) retention interval, 3) experience level of trainees, 4) length of practice and 5) type of control group. The results of their meta-analysis showed a positive effect of MI when the following criteria were met: examination mainly of the cognitive aspects of the task performance, short retention interval, participants being novices to the task, and the MI session being about 20 minutes or shorter. They reported a non-significant trend for larger effects of MI compared with a non-treatment group and with an equivalent control treatment group.

\section{Imagery models and frameworks in the sports literature} In the sports psychology literature, six imagery models and frameworks were reviewed by Guillot and Collet [26]. The models included a four-component scheme originally designed by Martin et al., who described how MI influences cognitive, affective and behavioural outcomes [20]. The six-stage model from Munroe et al. was also evaluated, including the well known ' $W$ ' questions (where, when and why do athletes use MI, and what do they imagine?) [28]. This qualitative method includes the type (visual, kinaesthetic) and perspective (internal, external) of MI. MacIntyre and Moran extended the framework of Munroe et al. by adding the question: 'How should MI be executed and used by athletes?' [29], and they described a multimodal model that includes definition, outcome and importance of MI. Holmes and Collins introduced the PETTLEP framework, building on findings in functional neuroscientific research literature and experience in sport psychology [30]. PETTLEP aims to facilitate designing MI interventions for athletes, and comprises seven components (physical, environment, task, timing, learning, emotion and perspective). These components describe the physical position of the individual, the environment that has to be imagined, the task involved, the timing or duration of the imagery, the learning or changes involved during imagery, the emotions that are associated with the task, and imagery perspective. By contrast, the three-step model described by Watt et al. focused on MI ability and two image-generation approaches: 1) vividness, control, duration, ease, and speed; and 2) visual sensory methods [31]. The recent framework proposed by Guillot and Collet aimed to combine key components from previously described models. Their Motor Imagery 
Integrative Model in Sport (MIIMS) includes four MI outcomes: 1) motor learning and performance; 2) motivation, self-confidence and anxiety; 3 ) strategies and problem-solving; and 4) injury rehabilitation. The scheme aimed to combine different imagery types (visual, kinaesthetic, olfactory, tactile and auditory) to create a complete mental version of the movement [26].

\section{Motor imagery in medicine}

MI research from sports psychology has been used in medicine, particularly in neurological rehabilitation [11-13]. Literature reviews have evaluated the overall beneficial effect of MI $[5,9,11]$, but none has described the MITS elements or temporal parameters. In this review, we analysed the MITS elements and temporal parameters that have been successfully used in different disciplines: Education, Medicine, Music, Psychology and Sports (in this review, we use the term 'Sports' for all studies that include athletes as participants and the term 'Psychology' for all studies including healthy participants who are not athletes).

\section{Methods}

\section{Search terms and search strategy}

Search terms were identified by a previous search of databases (including PubMed) and internet search engines (including Google and Google Scholar). Additionally, each searched database was checked for predefined $\mathrm{MeSH}$ terms, and where available, these terms were integrated into the search strategy. The following terms were used: 'mental imagery', 'mental practice', 'mental rehearsal', 'mental movements', 'eidetic imagery', 'visual imagery', 'guided imagery', 'motor imagery' and 'mental training'. The Appendix provides the complete search strategy for Scopus. The Scopus search strategy was adapted to individual databases and trial registers to account for specific vocabulary and syntax rules. No restrictions were made regarding year of publication, study design or age of the study population.

\section{Study identification}

Table 1 provides an overview of all databases, trial and dissertation registers, and conference proceedings searched. Database retrievals were imported into a reference management software package (EndNote; Thomson Reuters, Carlsbad, CA, USA). In total, 21,739 references were retrieved in February 2007. The literature search was repeated in June 2010 for references published between spring 2007 and 2010 in the largest databases of each discipline: the Education Resources Information Center (ERIC), Scopus, Répertoire International de Littérature Musicale (RILM), PsycINFO and SPORTDiscus. This search resulted in 5,741 additional references.

\section{Study selection criteria}

The references were selected for review inclusion based on the following criteria:

- Any design of quantitative intervention studies with a focus on imagining movements.

- Studies that included healthy volunteers, students, children, professionals, athletes or patients from any discipline.

- Study intervention that focused on motor skill, performance or strength improvement.

The following exclusion criteria were used:

- Mental practice not related to movements (audition, odour, any kind of visual imagery with static pictures).

- Mental practice based on a computer-animated technique (virtual reality).

- Mental practice used during a functional magnetic resonance imaging (fMRI) session.

- Mental practice carried out during hypnosis or psychotherapy (guided imagery, eidetic imagery)

- Mental practice used as mental rotation or diagnostic tool.

- Suggested frameworks without participant evidence or experience.

- Publication language other than English or German.

\section{Selection process}

During the manual selection process (Figure 1), articles were evaluated based on title, abstract or keywords. Two of the authors (CS and $\mathrm{RH}$ ) reviewed the articles; $\mathrm{CS}$ evaluated all references, and $\mathrm{RH}$ evaluated a randomly selected proportion (20\%) of the initial number of references selected from each discipline. Full texts were ordered if no decision could be made based on the available information. If one reviewer could not reach a decision for a reference, this reference was discussed by both reviewers, and if both reviewers had not been able to agree on a decision (which was not the case in this investigation) a third reviewer (JB) would have been consulted.

Owing to the large number of references, EndNote search options were used to eliminate studies based on the exclusion criteria.

To confirm the selection congruency between both independent reviewers, the inter-rater congruency was calculated. Reviewer agreement ranged between 78\% and 100\% (average 96\%) for the five disciplines. Because some studies reported more than one MI intervention, the total exceeded the number of included studies. Each MI intervention was subsequently analysed as an independent investigation.

\section{Data extraction}

Information on study methods, MITS elements and temporal parameters were extracted by three researches 
Table 1 Overview of searched databases, trial and dissertation registers and conference proceedings, and the number of references found

\begin{tabular}{|c|c|c|c|c|}
\hline Number & Discipline & Database & Searched time period & References found, $\mathrm{n}$ \\
\hline 1 & Education & Academic Search Premier & 1975 to Feb 2007 & 1040 \\
\hline 2 & Medicine & AMED & 1985 to Feb 2007 & 623 \\
\hline 3 & Education & ASSIA & 1987 to March 2007 & 353 \\
\hline 4 & & $\mathrm{AEI}$ & 1979 to Feb 2007 & 84 \\
\hline 5 & & BEl & 1975 to Feb 2007 & 18 \\
\hline 6 & Medicine & $\mathrm{BNI}$ & 1985 to Feb 2007 & 54 \\
\hline 7 & & CINAHL & 1982 to Feb 2007 & 1606 \\
\hline 8 & & Cochrane Library & 1948/1995 to march 2007 & 363 \\
\hline 9 & & Digital dissertations & 1930 to March 2007 & 30 \\
\hline 10 & & DIMDI & 1967 to March 2007 & 130 \\
\hline 11 & Sports & EMAERALD & 1965 to March 2007 & 134 \\
\hline 12 & Education & ERIC & 1966 to Feb 2007 & 795 \\
\hline 13 & Medicine & GMS meetings & 2002 to March 2007 & 1 \\
\hline 14 & & ISI Proceedings & 1990 to March 2007 & 241 \\
\hline 15 & Music & JSTOR & 1665 (1800) to Feb 2007 & 200 \\
\hline 16 & Psychology & PsycINFO & 1887 to Feb 2007 & 4588 \\
\hline 17 & Music & RILM & 1967 to March 2007 & 180 \\
\hline 18 & Medicine & Scopus & 1996 to Feb 2007 & 2550 \\
\hline 19 & Sports & SPORTDiscus & 1800 to Feb 2007 & 4023 \\
\hline 20 & Sports & SPORLIT, SPOFOR, SPORMED & 1974 to Jan 2007 & 589 \\
\hline 21 & Medicine & ClinicalTrials.gov & 1997 to March 2007 & 12 \\
\hline 22 & & ISRCTN & 1998 March 2007 & 2 \\
\hline 23 & & National Research Register & 2000 to March 2007 & 16 \\
\hline 24 & & Web of Science & 1970 to March 2007 & 2837 \\
\hline 25 & & Zetoc & 1993 to March 2007 & 1270 \\
\hline Total & & & & 21,739 \\
\hline
\end{tabular}

AMED = Allied and Complementary Medicine, ASSIA = Applied Social Sciences Index and Abstracts, AEI = Australian Education International, BEI = British Education Index, BNI = British Nursing Index, CINAHL = Cumulative Index to Nursing and Allied Health Literature, DIMDI = German Institute for Medical Documentation and Information, ERIC = Educational Resources Information Center, GMS = General Medical Services, ISI = Web of Knowledge, JSTOR = Journal STORage, RILM = Répertoire international de Littérature Musicale, SPORLIT = Sporlit(eratur), SPORFOR = Sporfor(schung), SPORMED = Spormed(ia), ISRCTN = International Standard Randomised Controlled Trial Number

(RB, AS, CS) and checked for accuracy (CS). Table 2 summarises all extracted information. Figure 2 illustrates the temporal parameters and the MITS terminology.

\section{Study quality rating}

Two rating lists were used because studies with different quantitative designs were included. The Physiotherapy Evidence Database (PEDro) list was used to evaluate randomised controlled trials (RCTs) (maximum of ten points) and non-RCTs (maximum of eight points) [32]. For case series or single cases experimental designs, the 11-point Single Case Experimental Design (SCED) scale was used [33]. All studies were rated by CS based on detailed rating guidelines. Studies received one point for each fulfilled methodological criterion on the respective rating list. The higher the achieved score, the better the study quality.

\section{Data analysis}

Raw information was extracted into Excel (Microsoft Corp., Redmond, WA, USA). After coding and classification, MI intervention data was imported into statistical analysis software packages (SPSS versions 16 and 17 (SPSS Inc., Chicago, IL, USA), MATLAB version 2009b (The MathWorks Inc., Natick, MA, USA)) for frequency analyses, frequency and mean comparison tests and visualisation. MI intervention data was not pooled or analysed for significant differences because of the variability in experimental settings and missing information in MI intervention descriptions. The heterogeneity between MI interventions was also present in standard deviations of temporal parameters. All MI interventions were classified into two categories: positive change (129 MI interventions, $91.5 \%)$, and no or negative change from pre- to post-test (12 MI interventions, 8.5\%). MITS elements and temporal 


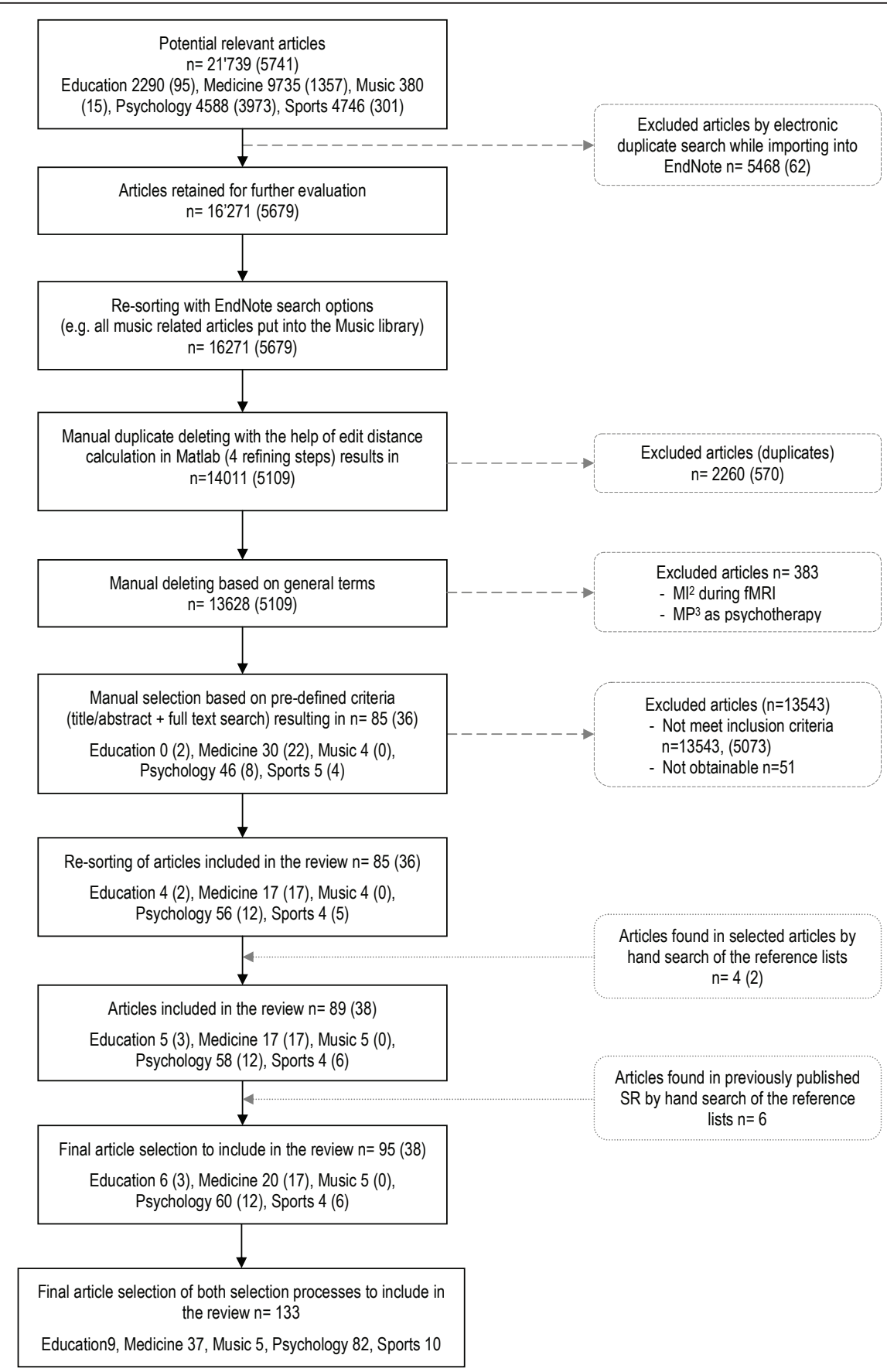

Figure 1 The literature selection process. Numbers in brackets indicate references retrieved from the search in June 2010. MI = motor imagery; MP = mental practice.

parameters of studies with positive change were summarised under the term 'average positive MI intervention' and used for comparison in three analyses.

First, trend analyses were performed to identify MITS elements for MI interventions with positive results versus no changes or negative results. Further analyses aimed to identify changing trends in MITS element frequencies in MI interventions with positive results for five different disciplines, integration approaches, MI training focus, session type, age and gender groups and MI intervention modifications. Secondly, the $\chi^{2}$ was used to test for significant differences between actual and expected observation frequencies for each MITS element. The tests were performed if $20 \%$ of the 
Table 2 Overview of extracted MITS ${ }^{\text {a elements }}$

\begin{tabular}{|c|c|c|c|c|}
\hline Number & $\begin{array}{l}\text { MITS } \\
\text { element }\end{array}$ & MITS element description and categories & $\begin{array}{l}\text { PETTLEP } \\
\text { category }\end{array}$ & $\begin{array}{l}\text { Dominant category found } \\
\text { in successful } \mathrm{Ml}^{\mathrm{b}} \\
\text { interventions }\end{array}$ \\
\hline 1 & Position & $\begin{array}{l}\text { Describes the position of the individual during Ml practice as task-specific or } \\
\text { not task-specific. }\end{array}$ & Physical & Task-specific \\
\hline 2 & Location & Describes the location of MITS as task-specific or not task-specific. & Environment & Task-specific \\
\hline 3 & Focus & $\begin{array}{l}\text { Each task consists of different parts. Focus of the intervention classifies the } \\
\text { main focus of task-related activities that had to be imagined: motor, cognitive } \\
\text { or strength. }\end{array}$ & Task & Motor-focused activities \\
\hline 4 & Order & $\begin{array}{l}\text { Describes temporal order of } \mathrm{MI} \text { and } \mathrm{PP}^{\mathrm{C}} \text { trials. MI trials could have been } \\
\text { performed before, between, after or simultaneously with PP. }\end{array}$ & Timing & $\mathrm{Ml}$ after PP \\
\hline 5 & Integration & Describes whether $\mathrm{Ml}$ practice has been added to PP or embedded into PP. & & Added \\
\hline 6 & $\begin{array}{l}\text { Ml instructions } \\
\text { medium }\end{array}$ & $\begin{array}{l}\text { Ml instructions can be provided differently through one or more media } \\
\text { types. Media type was scored as acoustic, written or visual. More than one } \\
\text { media type could be assigned. }\end{array}$ & Learning & Acoustic \\
\hline 7 & $\begin{array}{l}\text { Instruction } \\
\text { mode }\end{array}$ & $\begin{array}{l}\text { In addition to the instruction medium, the mode was classified as live or } \\
\text { pre-recorded (for example, using tape or video). }\end{array}$ & & Live \\
\hline 8 & Supervision & $\begin{array}{l}\text { MITS could have been supervised or not supervised by an instructor present } \\
\text { during the session. }\end{array}$ & & Supervised \\
\hline 9 & Directedness & $\begin{array}{l}\text { MITS could have been directed }{ }^{d} \text { or non-directed when stepwise guidance was } \\
\text { present or not. }\end{array}$ & & Non-directed \\
\hline 10 & $\begin{array}{l}\text { Instruction } \\
\text { type }\end{array}$ & $\begin{array}{l}\text { The description of MI instructions varied. Instructions could cover detailed } \\
\text { descriptions for each part of the task that had to be imagined, simple } \\
\text { keywords, or coarse (broad) overall MI instructions. }\end{array}$ & & Detailed \\
\hline 11 & $\begin{array}{l}\text { Instruction } \\
\text { individuali- } \\
\text { sation }\end{array}$ & $\begin{array}{l}\text { MI instructions could have been individualised to the participant's problems } \\
\text { with the task that had to be imagined (tailored), or could have been the } \\
\text { same for each participant (standardised). }\end{array}$ & & Standardised \\
\hline 12 & $\begin{array}{l}\text { Familiari- } \\
\text { sation }\end{array}$ & $\begin{array}{l}\text { Describe whether study participants had received an Ml familiarisation session } \\
\text { before the Ml intervention began. }\end{array}$ & & No familiarisation \\
\hline 13 & Change & $\begin{array}{l}\text { Indicated whether modification of content, duration or dosage of the Ml } \\
\text { training occurred, to facilitate the learning process during the Ml intervention } \\
\text { period. }\end{array}$ & & \\
\hline 14 & Ml session & $\begin{array}{l}\text { MITS could have been classified as group sessions with more than one } \\
\text { person participating in a MITS or as individual sessions with one participant } \\
\text { only. }\end{array}$ & Emotion & Individual \\
\hline 15 & Eyes & $\begin{array}{l}\text { During the Ml, the participant's eyes could have been closed or open. In } \\
\text { some interventions, participants started with one condition and changed to } \\
\text { the other after one or several MITS. }\end{array}$ & & Closed \\
\hline 16 & Perspective & $\begin{array}{l}\text { During the } \mathrm{Ml} \text {, participants could have imagined the task from an internal or } \\
\text { external perspective. In some interventions, participants started with one } \\
\text { condition and changed to the other after one or several MITS. }\end{array}$ & Perspective & Internal \\
\hline 17 & Mode & $\begin{array}{l}\text { During the Ml, participants could have used a kinaesthetic or visual mode. In } \\
\text { some Ml interventions, participants started with one condition and changed } \\
\text { to the other during one or after several MITS. }\end{array}$ & & Kinaesthetic \\
\hline
\end{tabular}

expected frequency showed an amount of 5 or more [34]. Thirdly, for temporal parameters, normal distribution was tested using the Kolmogorov-Smirnov test, and variance homogeneity was confirmed by the Levene test. Depending on the test results, group means were compared using Student $t$-test or Mann-Whitney $U$-test. The tests were used if at least five observations were available to estimate the statistic. For all temporal parameters, group means were compared against the average positive MI intervention.
For all statistical tests $\mathrm{p} \leq 0.05$ was considered significant.

\section{Results}

The bar charts of plot A (Figure 3; Figure 4; Figure 5; Figure 6; Figure 7; Figure 8; Figure 9; Figure 10; Figure 11; Figure 12; Figure 13; Figure 14; Figure 15) show the frequencies of $\mathrm{MI}$ interventions that reported details on MITS elements. For each MITS element, one or more categories were considered; for example, for the 


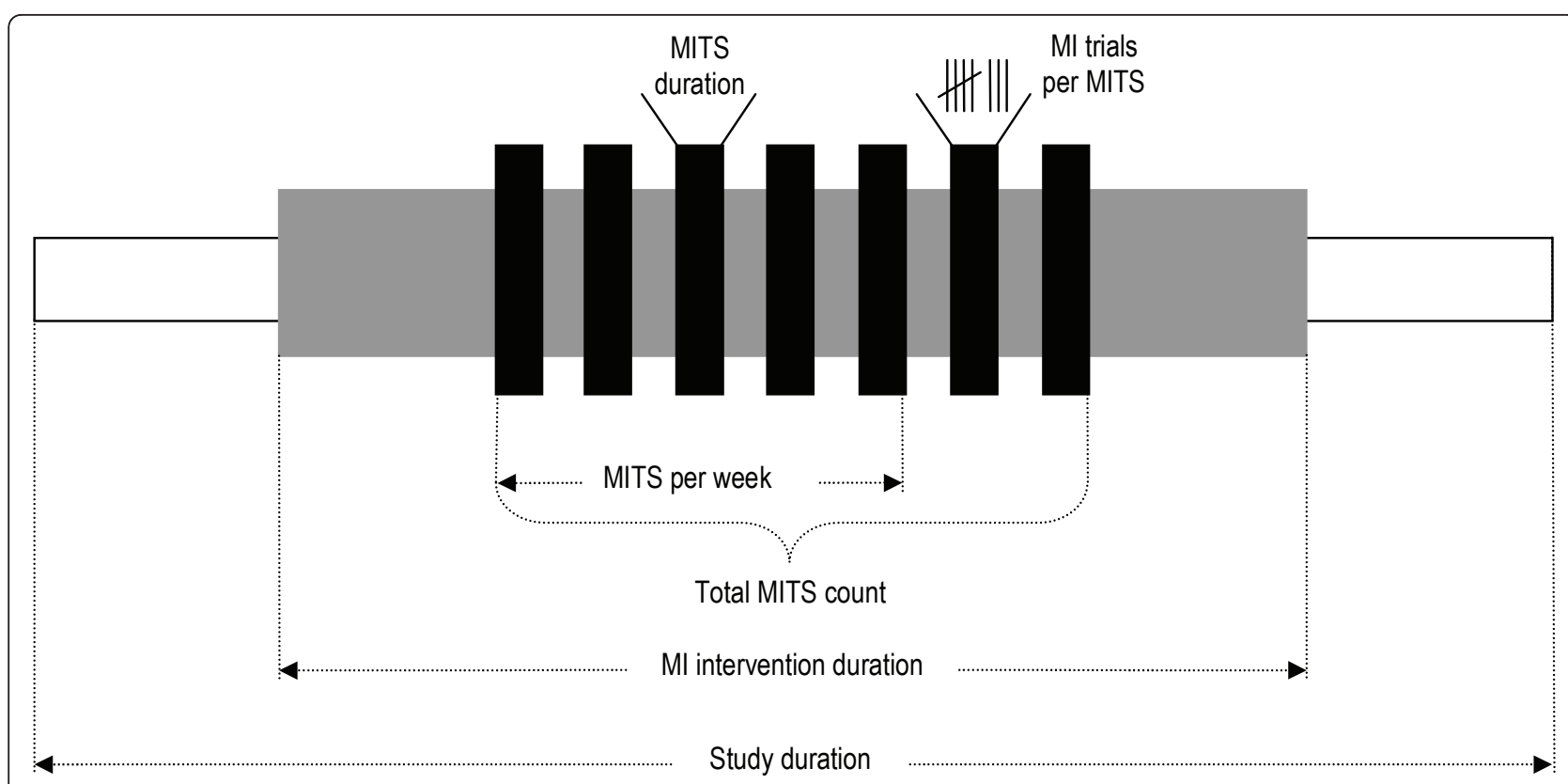

Figure 2 Overview of extracted and calculated temporal parameters. $\mathrm{MI}=$ motor imagery; MITS = motor imagery training session; total $\mathrm{MI}$ time: $=($ total MITS count $) \times($ MITS duration $)$.

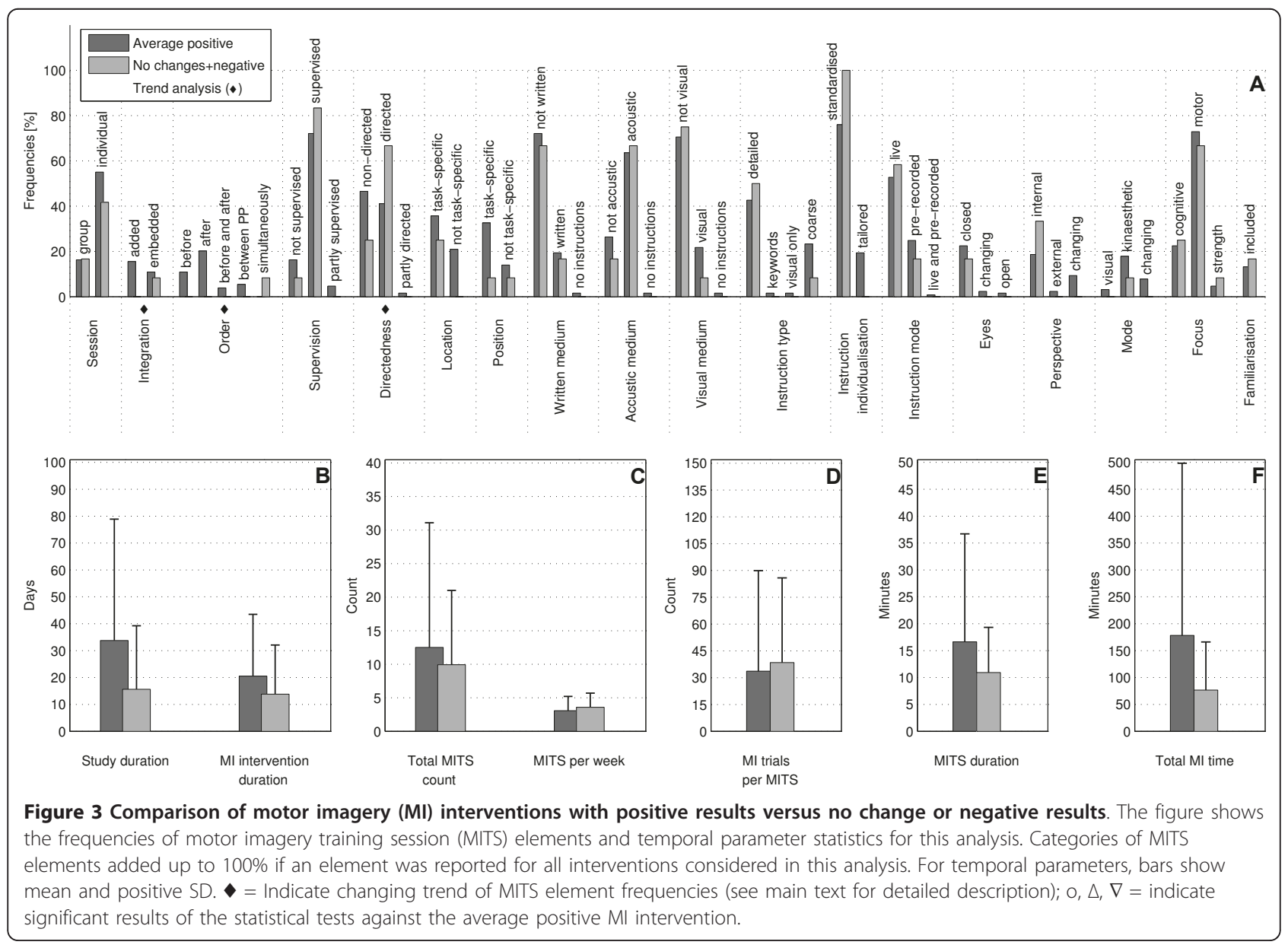



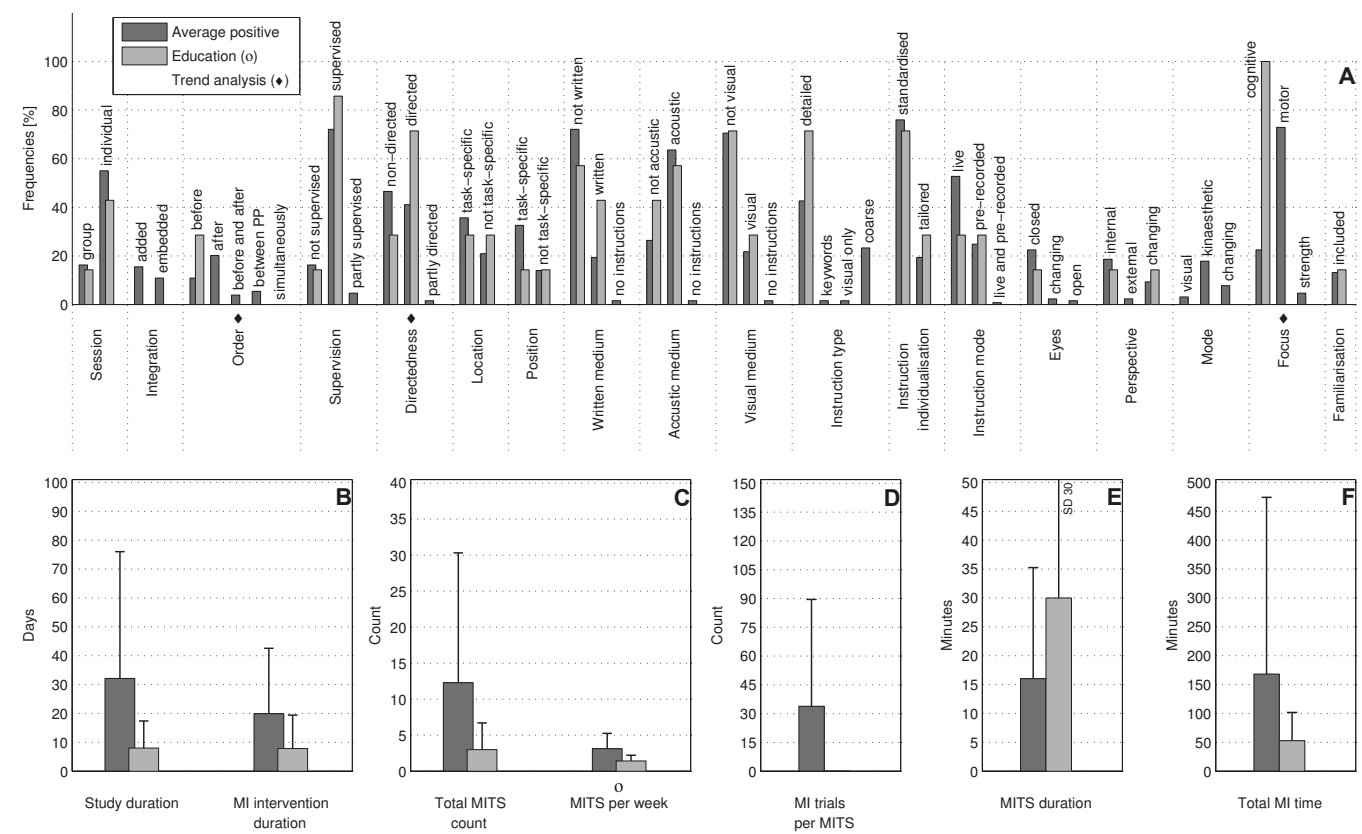

Figure 4 Comparison of average positive motor imagery (MI) intervention versus discipline-specific MI interventions in Education. The figure shows the frequencies of motor imagery training session (MITS) and temporal parameter statistics for successful interventions. Categories of MITS elements added up to $100 \%$ if an element was reported for all interventions considered in this analysis.. For temporal parameters, bars show mean and positive SD. = Indicate changing trend of MITS element frequencies (see main text for detailed description); $0, \Delta, \nabla=$ indicate significant results of the statistical tests against the average positive Ml intervention.
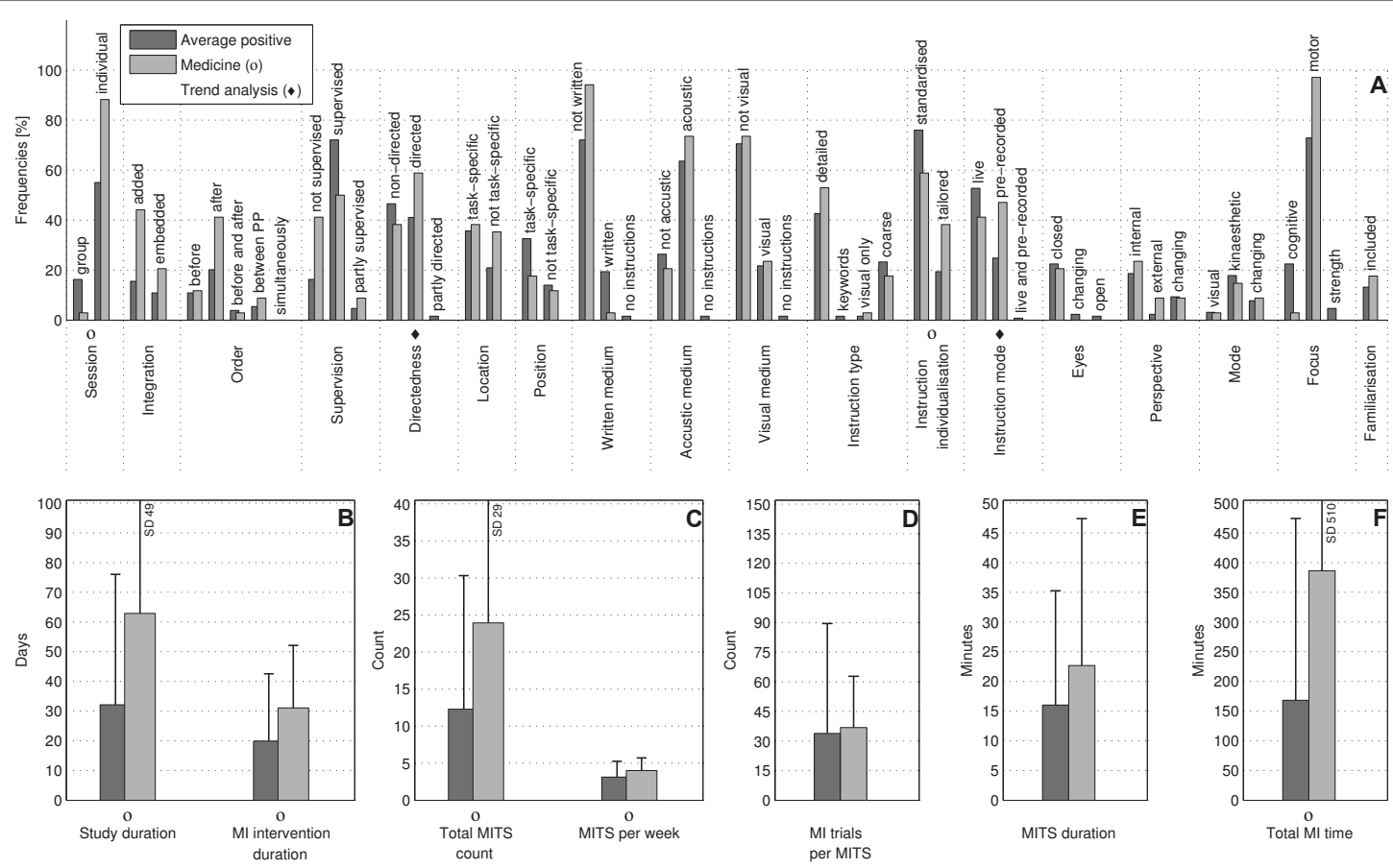

Figure 5 Comparison of average positive motor imagery (MI) intervention versus discipline-specific MI interventions in Medicine. The figure shows the frequencies of motor imagery training session (MITS) and temporal parameter statistics for successful interventions. Categories of MITS elements add to 100\%, if an element was reported for all interventions considered in this analysis. For temporal parameters, bars show mean and positive standard deviation (SD). = Indicate changing trend of MITS element frequencies (see main text for detailed description); O, $\Delta, \nabla=$ indicate significant results of the statistical tests against the average positive $\mathrm{Ml}$ intervention. 


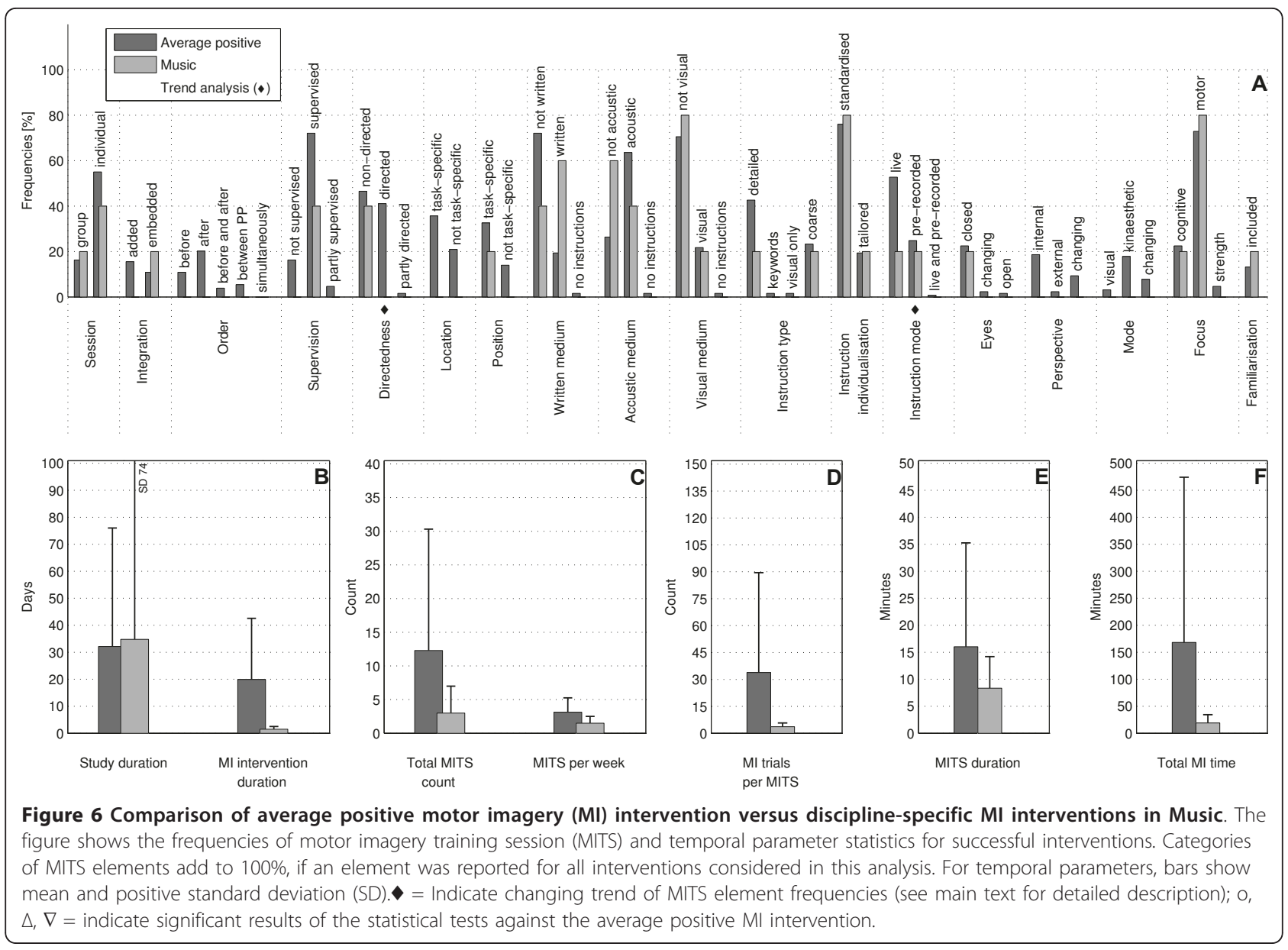

MITS element 'session', the categories 'group' and 'individual' were analysed. The categories of MITS elements added up to $100 \%$ if an element was reported for all MI interventions in the respective analysis. Relevant trends in MITS elements, as reported in the text below, were marked in plots A to F in the same figures. For temporal parameters, bars show mean and positive SD.

\section{Study characteristics}

In total, 133 studies were included in the analysis, reporting $141 \mathrm{MI}$ interventions in five disciplines: Education (9 Interventions), Medicine (37), Music (5), Psychology (79) and Sports (11). For the studies published between 1941 and 2010, there were peaks in 1989/1990 (8 publications), in 2004 (18) and 2007 to 2009 (38). In Medicine, MI publications first appeared in 2000, with a steady increase until 2010. These studies originated from Europe, Australia/New Zealand, the Americas, Asia, and the Middle East.

The study designs comprised 91 randomised controlled trials (RCTs), 22 controlled clinical trials (CCTs), 15 case series (CSs) and 13 single-case research designs (SCRDs). Study quality was rated on a 10-point scale for
RCTs (4 to 9), an 8-point scale for CCTs (3 to 6), an 11-point scale for CSs (4 to 11), and on an 11-point scale for SCRDs (7 to 10).

On average, RCTs and CCTs scored 6 on the 10-point PEDro scale, whereas CSs and SCRDs scored 6 and 8, respectively, on the 11-point SCED scale (on both, higher scores indicate better quality). Examples of MI instructions were available for $29 \mathrm{MI}$ interventions, and changes in MI content during the MI intervention period were reported in $31 \mathrm{MI}$ interventions. An overview of essential study characteristics is provided for each discipline separately (Table 3, Table 4, Table 5, Table 6 and Table 7).

\section{Comparison of $\mathrm{Ml}$ interventions with positive results versus no change or negative results: how should a successful $\mathrm{MI}$ intervention be implemented?}

The MITS elements for all MI interventions were compared (Figure 3A). Frequency analyses of MI interventions with positive results revealed a number of key MITS elements present in a successful intervention design: MI was performed in individual sessions and added after PP; MI sessions were supervised and not 


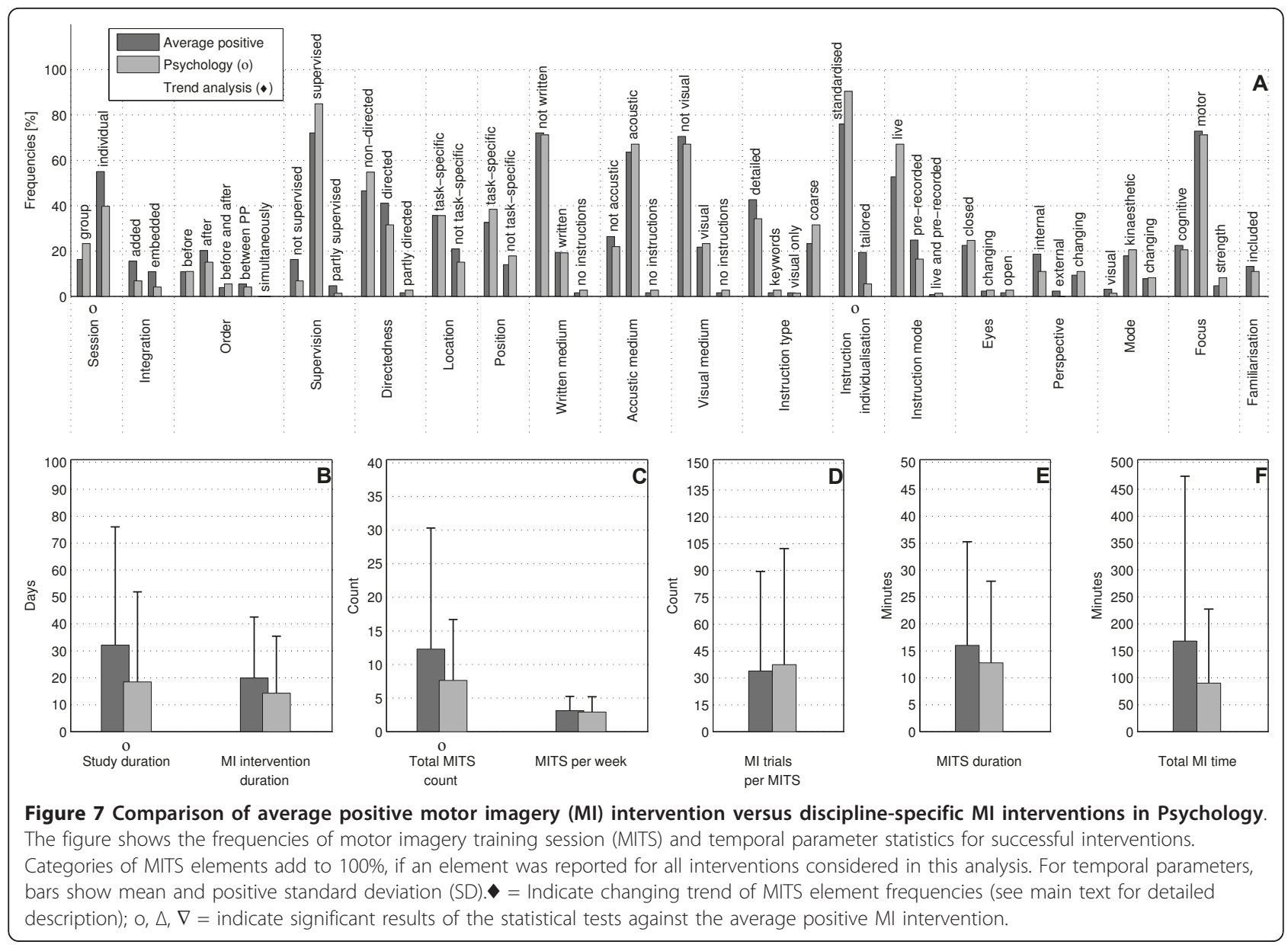

directed; locations of MITS and the position of the participants during MI were both task-specific; participants received acoustic and detailed MI instructions, which were mainly standardised and live; during MI practice, participants kept their eyes closed.; the perspective used during MI practice was chosen from an internal view combined with a kinaesthetic MI mode; and MI interventions were mainly investigated with motor-focused tasks.

Only 17 reports mentioned an MITS for familiarisation before the MI intervention began. The reporting rate of all MITS elements ranged between $26 \%$ for the description of closed or open eyes to $95 \%$ for MI instruction individualisation. The most frequently reported MITS elements in successful MI interventions are listed in Table 2.

MI interventions with no change or with negative results predominantly used directed MITS. If MI integration was reported, MITS were embedded between or performed simultaneously with physical trials. Owing to the lack of reporting, the ordering of MI and PP could not be identified in $90 \%$ of all MI interventions. Only two MI interventions mentioned an MITS for familiarisation before MI intervention began. For the subsequent analyses only successful MI interventions with positive results were considered.

MI interventions with positive results had almost twice the duration of MI interventions with no change or negative results: study duration (34 days), MI intervention duration (21 days), total MITS count (13), (the number 13 stands for the number of MITS in MI interventions with positive results)MITS duration (17 minutes) and total MI time (178 minutes). By contrast, MI interventions with no change or negative results had a larger number of MITS per week (3) and a larger number of MI trials per MITS (34).

\section{Comparison of positive $\mathrm{Ml}$ interventions in five different disciplines: how do different disciplines use MI?}

In the described analyses, only positive MI interventions were considered. The two disciplines with the youngest participants were Psychology (aged up to 9 years) and Sports (10 to 19 years). Most MI interventions were carried out with students (20 to 29 years) in Education, Psychology, Music, and Sports. Participants aged 50 and older were included only for Medicine and Psychology. 


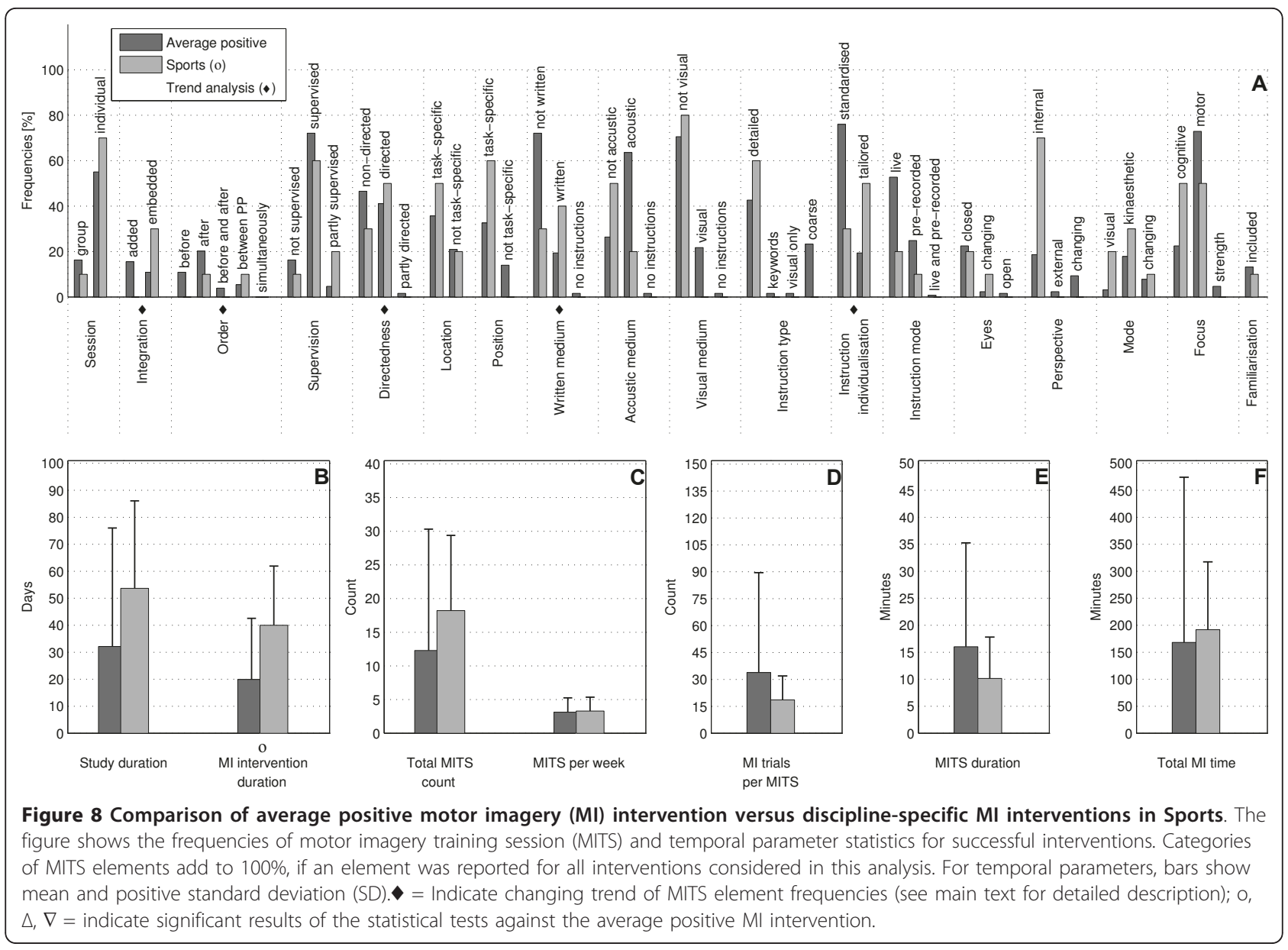

Gender-specific investigations were carried out in Medicine, Psychology and Sports.

Detailed discipline-specific frequency analyses of MITS elements revealed the following differences (italics) from the average positive MITS.

For Education, participants (Figure 4A-F) performed MI predominantly before physical practice (PP) during directed MITS. Three MITS elements showed both categories: position of participants during MITS (task-specific and not task-specific), instruction mode (life and prerecorded), and perspective (internal and external). MI content focused on cognitive task-related activities. MI mode was not reported. Regarding the temporal parameters in Education, the study and MI intervention duration and the total MI time were less than half of those in the average positive MI intervention, but the MITS duration was twice as long as in the average positive MITS. The number of MI trials per MITS was not reported.

MI interventions in Medicine (Figure 5A-F), the MI interventions predominantly used directed MITS with pre-recorded MI instructions. All temporal parameters had longer durations and total counts compared with the average positive MITS, especially for study and MITS duration, total MITS count and total MI time.

MI interventions in Music (Figure 6A-F) tended to be embedded into PP. MI instructions in Music were mainly written. Instruction mode and type allowed for more than one categorisation. Location of the MITS, and the MI perspective and mode used were not described. Almost all temporal parameters had lower durations and numbers than in the average positive MITS, particularly the number of MI trials per MITS, but the study duration was higher for MI interventions in Music.

MI interventions in Psychology (Figure 7A-F) most closely resembled the average positive MITS with similar distributions of MITS elements in instruction type and in MI perspective. MI interventions had the same number of MITS per week to the average positive MITS, but shorter MI intervention and MITS duration. Total MI time was half of that of the average positive MI intervention.

MI interventions in Sports (Figure 8A-F) reported embedded and directed MITS, [and after or between PP. Instructions during MITS were tailored and in written 


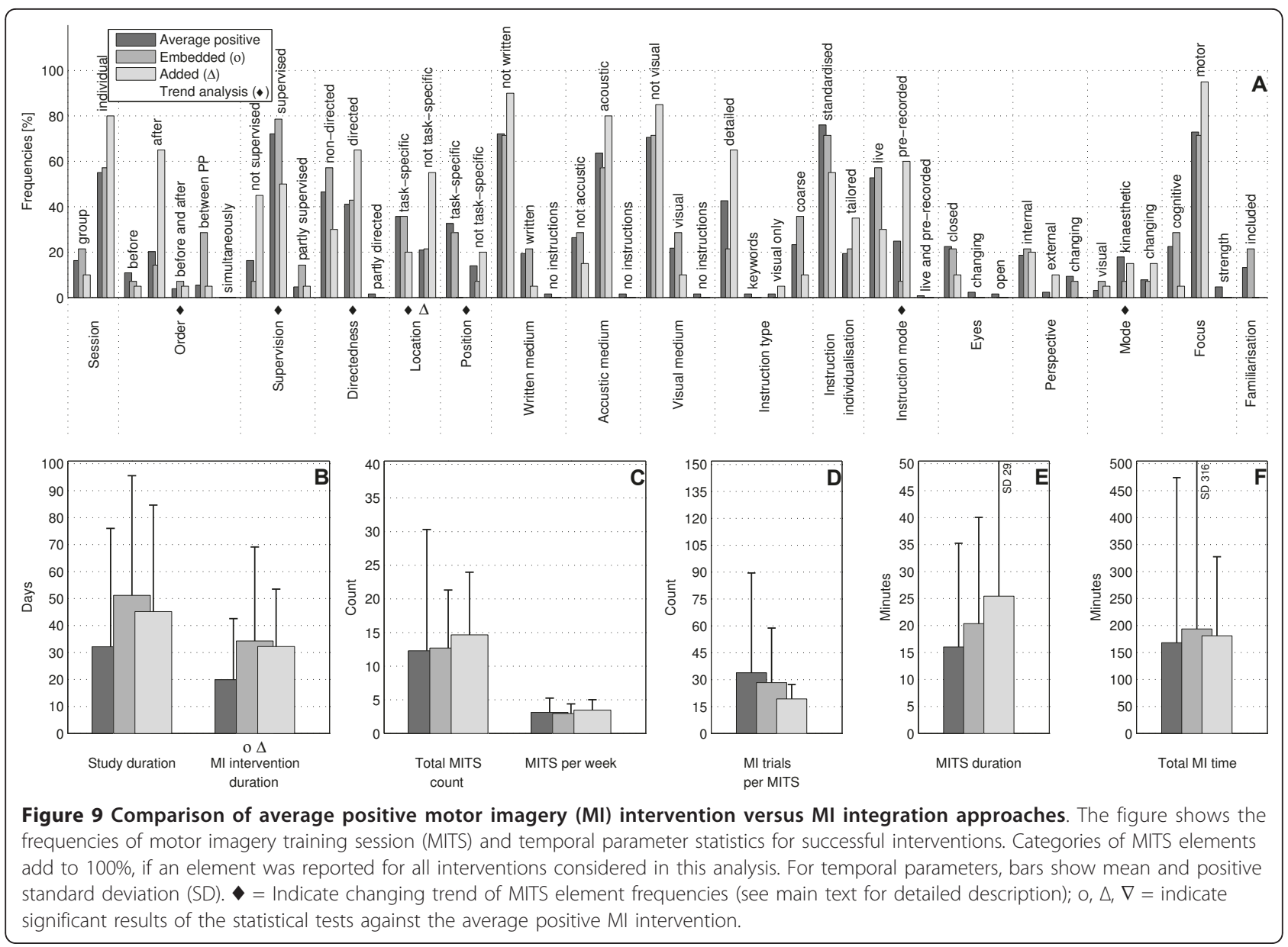

form. Study and MI intervention duration were almost twice as long as those in the average positive MI intervention. MI trials in a Sports MITS were only half of the number of the average positive MITS.

\section{Comparison of added and embedded MI integration approaches: does a specific set of MITS element for each method exist?}

This analysis was performed in successful MI interventions, which included PP in the study design. Of the 34 retrieved MI interventions, 20 described an added and 14 an embedded MI training method (Figure 9A-F). There was a preference for added MITS to be directed using pre-recorded instructions. Neither the locations of MITS nor the position of the participants during MI practice were task-specific. Added MITS used a kinaesthetic or mixed MI mode. MI training embedded into PP tended to be supervised, and was implemented between physical trials of the same task. Most MI interventions did not report details on location and position.

The averages of the temporal parameters of both categories (added and embedded) differed from those of the average positive MI intervention; however, there was wide variation between MI interventions. The duration of the study MI intervention and MITS duration were longer for both categories than in the average positive MITS, but the number of MI trials per MITS was lower. MITS duration was longer in the added than in the embedded training methods.

\section{Comparison of Ml interventions with different $\mathrm{Ml}$ training} focus: is MI particularly suited to one training focus?

Based on the primary focus of activities that were imagined, positive MI interventions were categorised into motor-focused (94), cognitive-focused (29) and strength-focused (6) activities. Compared with motor and cognitive-focused MI interventions, which were mainly published between the 1970s and 2010, the majority of strength-focused MI interventions were published in 1991 and in the period 2004 to 2009. Motor- and strength-focused MI interventions were often designed according to the average positive MITS (Figure 10A-F). Strength-focused MI interventions were investigated in healthy participants aged 20 to 39 years 
only. Motor-focused MI interventions had the highest number of MI trials per MITS and the longest MITS duration and total MI time.

Cognitive-focused MI interventions differed from the average positive MI intervention: there was a preference for MITS to be embedded and directed. Cognitivefocused MI interventions had shorter durations and lower numbers in all temporal parameters compared with motor-focused MI interventions.

\section{Comparison of $\mathrm{Ml}$ interventions with different $\mathrm{MI}$ session types: do group sessions require a different design from individual ones?}

This analysis could be performed for 37 positive MI interventions that reported details. In total, $21 \mathrm{MI}$ interventions described MITS in group sessions, and 71 in individual sessions (Figure 11A-F).

Group MITS tended to be directed and embedded into PP, and included MI practice before and after PP. Neither the locations of the MITS nor the position of the participants during MI practice were task-specific. Both the MI perspective used during MI practice and the MI mode changed. Total MI time and number of MI trials per session were only half those of the average positive MI intervention.

For the individual sessions, we investigated two options: directed and non-directed MITS. Compared with the average positive MI intervention, individual sessions had larger values for many of the temporal parameters, particularly total MI time.

\section{Comparison of $\mathrm{Ml}$ interventions with regard to participant age: did the implementation differ for particular age groups?}

Participant age in successful MI interventions was classified into seven categories: up to 9 years (2 interventions), 10 to 19 years (18), 20 to 29 years (63), 30 to 39 years (13), 40 to 49 years (2), 50 to 59 years (9), and 60 and older (20). Two MI interventions did not mention the age of the participant and were thus not considered in this analysis.

There were only two MI interventions with participants aged up to 9 years, published in 1973 [35] and 2004 [36]. Both were studies in Psychology, which considered healthy children of both genders with an average age of 6 and 9 years, respectively, and were supervised with acoustic instructions. Rapp and Schoder described the MI intervention as a non-directed group session with live and standardised instructions. Children closed their eyes during MI as they imagined a motor-focused task [35]. No further details were provided. Taktek et al. designed the MI intervention as a directed session with pre-recorded instructions [36]. Participants used a taskspecific position during MI, closed their eyes and used a kinaesthetic MI mode when imagining a cognitivefocused task. MI trials were preformed before PP trials using standardised and detailed instructions. Temporal parameters differed between both investigations.

The MI interventions $(\mathrm{n}=18)$ with teenagers (10 to 19 years) were in the fields of Psychology and Sports. Investigations were designed as directed individual sessions. Where reported, MI was practiced either before, or before and after PP. Participants received their MI instructions in written form. Only the number of MI trials per MITS was less than that in the average positive MI intervention (Figure 12A-F).

The MI interventions $(\mathrm{n}=63)$ with participants aged between 20 and 29 years most closely resembled the average positive MI intervention. Deviations were observed in three temporal parameters: study duration and total MI time were two-thirds of those in the average positive MI intervention, and participants performed more MI trials per session than in the average positive MI intervention.

MI interventions $(n=13)$ with participants aged between 30 and 39 years were mainly designed as added MITS with MI practice before PP and coarse (broad) MI instructions. MI mode was reported in two MI interventions as kinaesthetic and changing mode, respectively. Four temporal parameters had twice the duration or frequency than in the average positive MI intervention: study duration, MITS duration, total MITS count and total MI time. The number of MI trials per session was lower than those of the average positive MI intervention.

Only two MI interventions could be classified in the age group 40 to 49 years [37,38]. The MI intervention described by Vergeer and Roberts was performed with healthy participants of both genders [37]. MITS elements resembled those of the average positive MI intervention, with group sessions and a multimodal approach for MI instructions (written, visual and acoustic). The second article, published by Guillot et al., described an MI intervention with participants (male and female) who had burns [38]. The authors used added, individual, supervised and directed MITS. Participant received detailed, tailored and written instructions.

The MI interventions $(\mathrm{n}=9)$ with participants aged between 50 to 59 years were directed MITS (Figure 13A-F). Neither the locations of the MITS nor the position of the participants during MI practice were taskspecific. Internal and external MI perspective options were offered. A changing MI mode was preferred. Temporal parameters had almost twice the duration of MI study and $\mathrm{MI}$ intervention than in the average positive MI intervention.

The MI interventions $(\mathrm{n}=20)$ with participants aged 60 years and older were directed MITS, similar to the previous age group. There was no deviation in MITS 


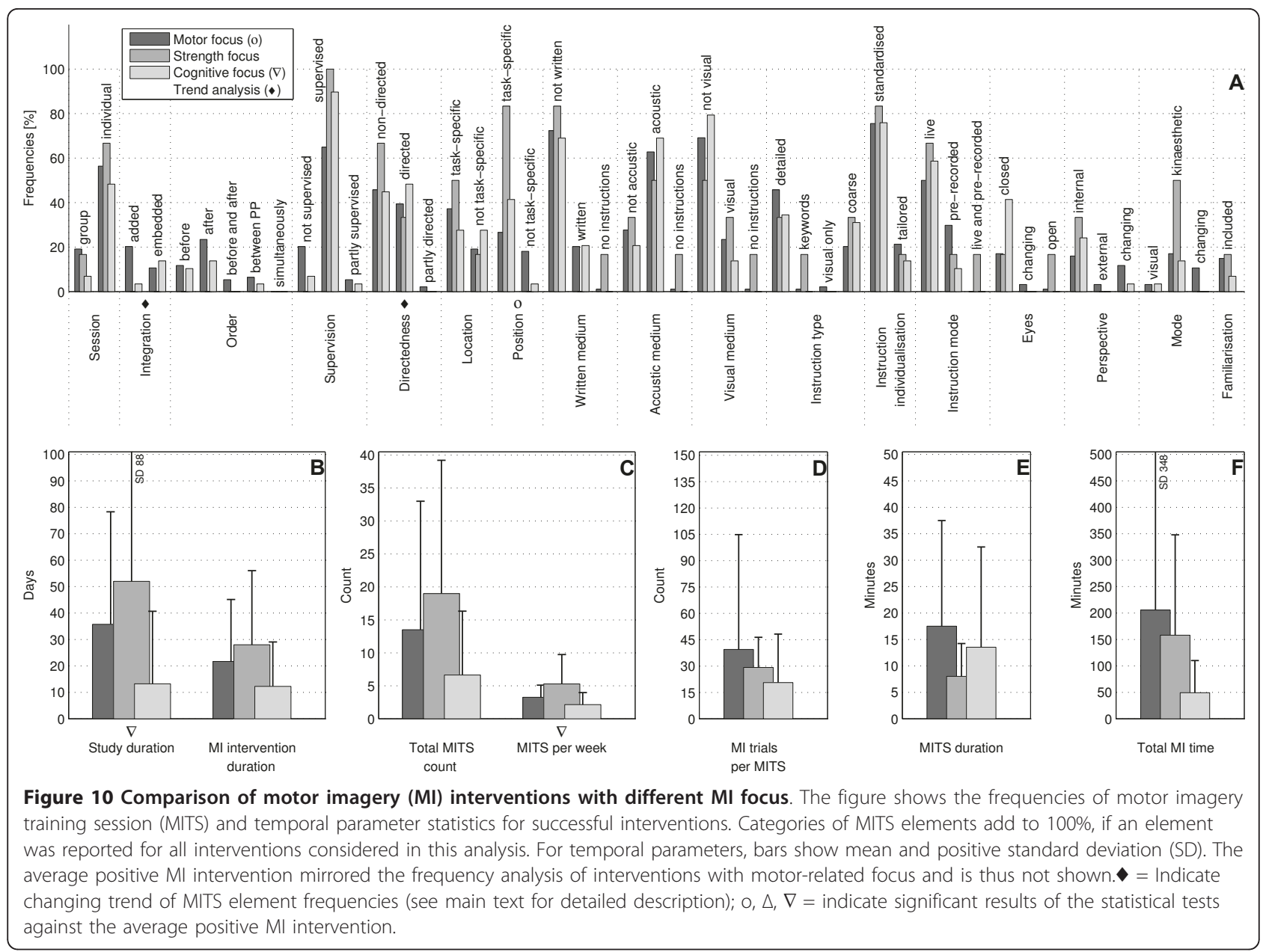

elements from those of the average positive MI intervention. Temporal parameters had a longer study duration and total MI time.

\section{Comparison of $\mathrm{Ml}$ interventions with regard to participant's gender: should gender-specific settings be considered for MITS implementation?}

Gender-specific analyses of positive MI interventions showed the following distribution: sixty-nine MI interventions with participants of both genders, eight MI interventions with female participants only and thirtyfour MI interventions with male participants only. Gender-specific investigations were carried out in Medicine, Psychology and Sports.

The MI interventions with participants of both genders $(n=69)$ were designed according to the average positive MI intervention. They had the longest study duration and total MI time and the largest number of MI trials per session compared with gender-specific MI interventions (Figure 14A-F).

The MI interventions $(n=8)$ with female participants only were primarily designed as embedded MITS with
MI trials between PP trials. The locations of the MITS were both task-specific and non-task-specific. MI instructions were live or pre-recorded. MI interventions with female participants were investigated with mainly cognitive-focused tasks. The MITS duration and number of MI trials were lower than those of MI interventions with both genders and with male participants only; however, the duration of the MI intervention was longer.

The MI interventions $(\mathrm{n}=34)$ with male participants used task-specific or non-task-specific positions, and the MI mode selected was the changing mode. Temporal parameters closely resembled those of the average positive MI intervention.

\section{Analyses based on change in content, duration and dosage of MI training: what MITS element variations have been investigated?}

Successful MI interventions were categorised with regard to change in $\mathrm{MI}$ intervention during the total $\mathrm{MI}$ intervention period into change $(\mathrm{n}=31)$ and no change $(\mathrm{n}=38)$. Change in MI intervention could include three domains: MI dosage, MI content and MI time. MI 


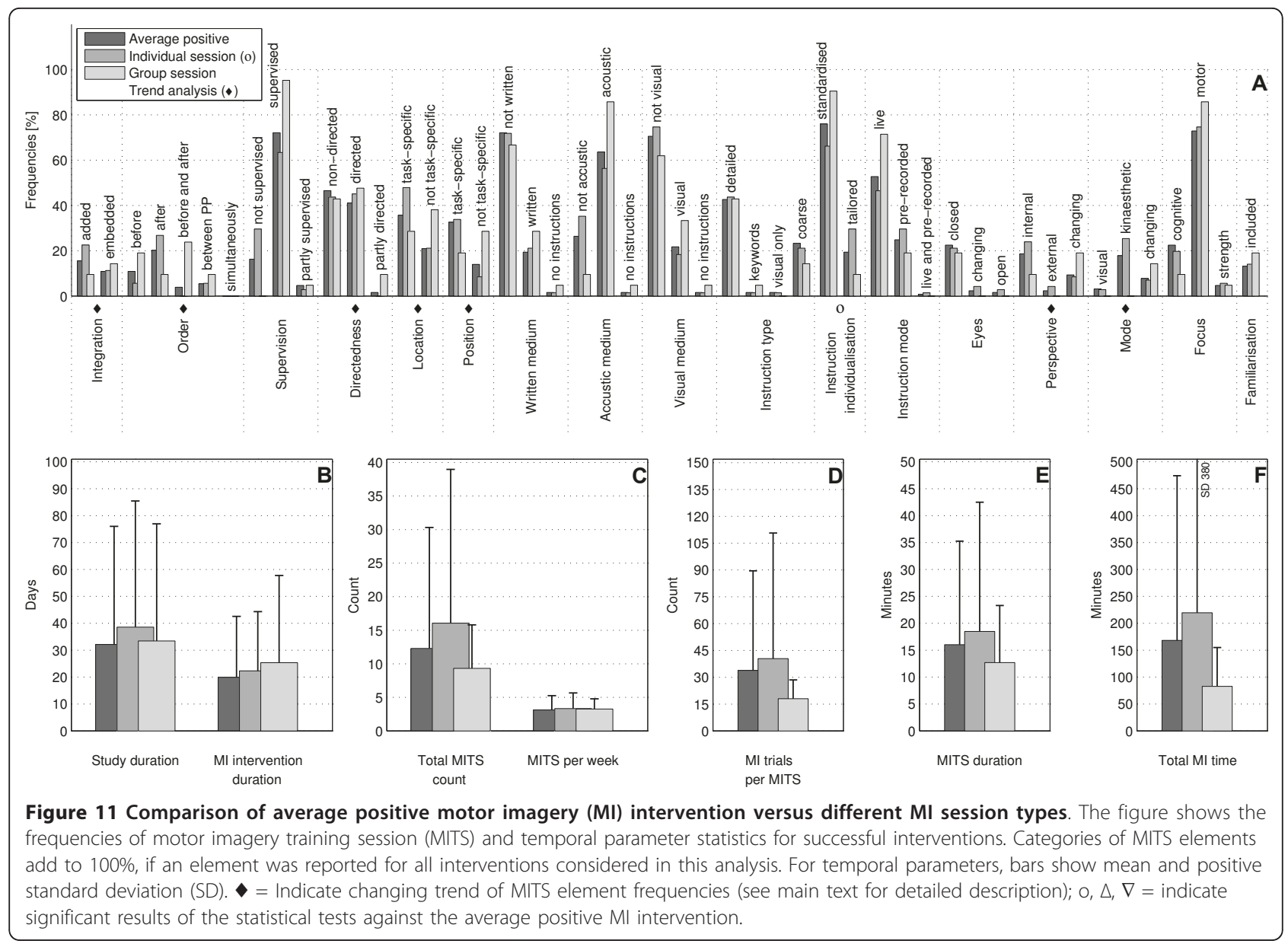

interventions were excluded from the analysis if a change was not clearly described $(n=55)$ or if the categorisation was not applicable $(n=5)$ due to the study design.

Only minor differences were found between categories (Figure 15A-F). MI interventions with a change during the MI intervention period included directed MITS. Duration of study and MI intervention, total MITS count, and total MI time were almost twice those of the average positive MI intervention. MI interventions without a change during the MI intervention period were designed as embedded MITS with shorter study duration, lower number of MI trials and lower total MI time than in the average positive MI intervention.

\section{Discussion}

\section{Summary of findings}

A question frequently raised by clinicians is 'How should motor imagery be done?'. Our literature review aimed to answer this question and to describe which elements characterise successful MITS. It was not our intention to evaluate the effectiveness of MI or to compare effect sizes, as this has already been addressed in other literature reviews $[1,6,11,13]$. The results of the trend analyses revealed changes in the frequencies of the MITS elements, which represent important variations between MI interventions. In addition, the review identified differences between the studies with positive results and those with no changes or negative results. Thus, the trend analyses might help clinicians to implement MI interventions successfully. By contrast, the $\chi^{2}$ test revealed general frequency distribution differences only, which were often caused by frequency variations and did not represent actual trend changes. Owing to limitations in the reporting rates, the $\chi^{2}$ test for MITS elements and the group mean comparison tests for temporal parameters could not be applied in many cases. We expect that our trend analyses in combination with the statistical test would be able to serve as indicators for potential future research directions.

Our analyses considered the differences in specific disciplines (Education, Medicine, Music, Psychology, Sports), MI integration types (added/embedded), session types (individual/group), focus of the task (motor, cognitive, strength), age, gender groups (female, male, both ) and change in content, duration and dosage. From 141 


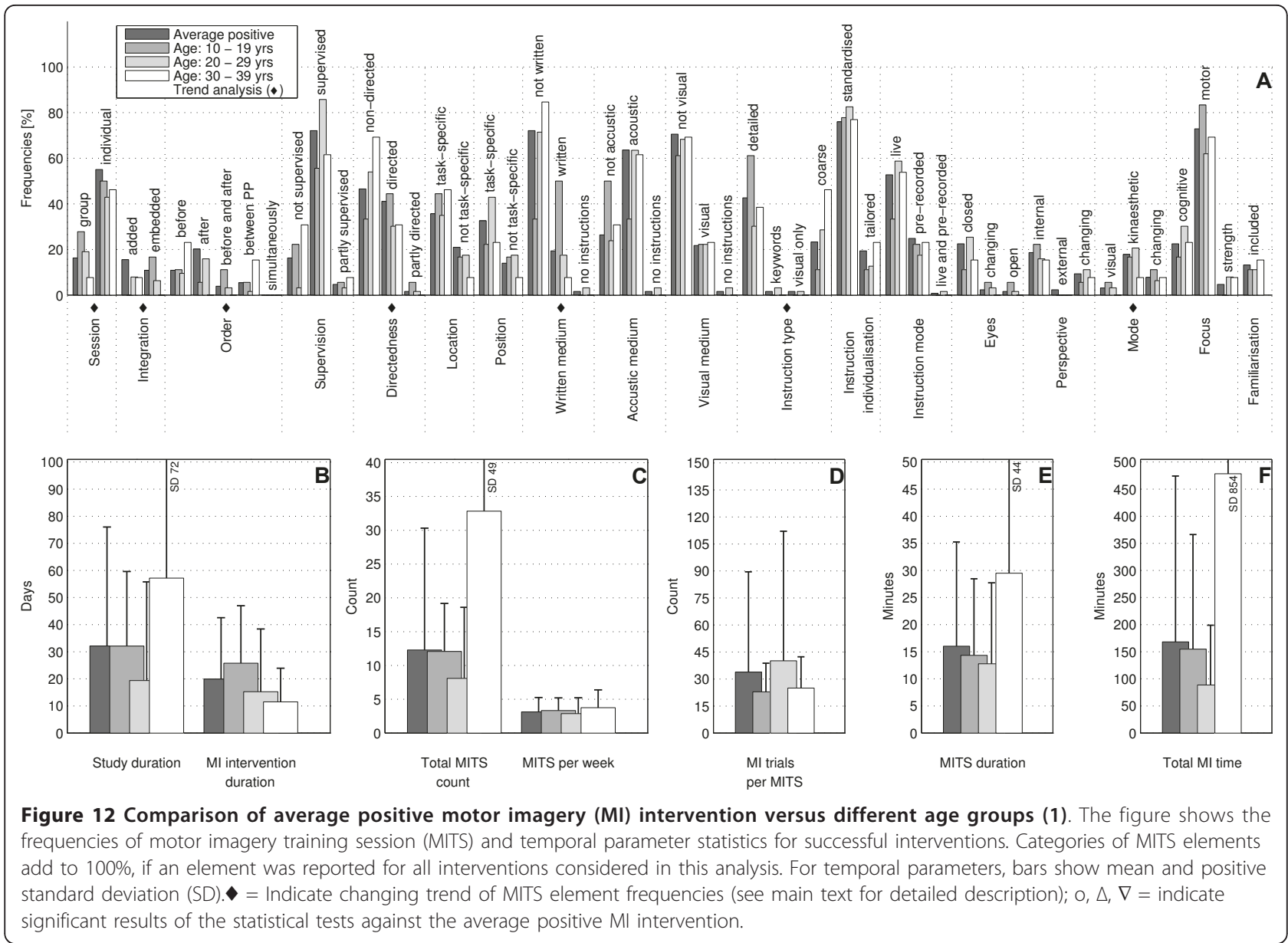

MI interventions, data were extracted and analysed for 17 MITS elements based on the PETTLEP approach and 7 temporal parameters.

\section{MI intervention outcome}

The comparison of the MI interventions with positive results versus those with no change or negative results provided the basis for all subsequent analyses. An average positive $\mathrm{MI}$ intervention was derived comprising MITS elements and temporal parameters. Characteristics of the average positive $\mathrm{MI}$ intervention were seen in studies in Psychology, in interventions with motorfocused or strength-focused tasks in all disciplines, in interventions with participants aged 20 to 29 years old, and in interventions with both genders. Four MITS elements differed between the MI interventions with positive results and those with no change or negative results: order (embedded/simultaneous), directedness (directed), number of MITS per week $(\mathrm{n}=3)$ and number of MI trials per MITS $(n=34)$. We hypothesise that several of these elements jointly inhibit positive results. Depending on the length of a MITS and the experience level of the participant, the most frequent number of
MITS per week chosen in successful MI interventions was three.

Data analyses determined that the average MITS duration was 17 minutes, with 34 MI trials per MITS. Both of these temporal parameters were also retrieved in the review of Feltz and Landers, published in 1983 [1], which yielded similar values. Our results suggest that not more than two MI trials per minute per MITS might be performed.

MI interventions with no change or negative results were present in all four study designs (RCT, CCT, CS and SCRD), with a higher average quality score for SCRDs than for RCTs. Therefore, it cannot be concluded that a certain design leads to a negative outcome.

\section{Discipline-specific intervention adaptation}

The use of imagery originated in the field of Psychology, with investigations dating back to publications in 1880 and $1897[39,40]$. Presumably, MITS adaptations were necessary to direct each step of a surgical procedure in Education, to tailor imagery tasks to the needs of participants in Medicine, to use written instructions (musical notes) in Music, and to embed MI between PP trials as 


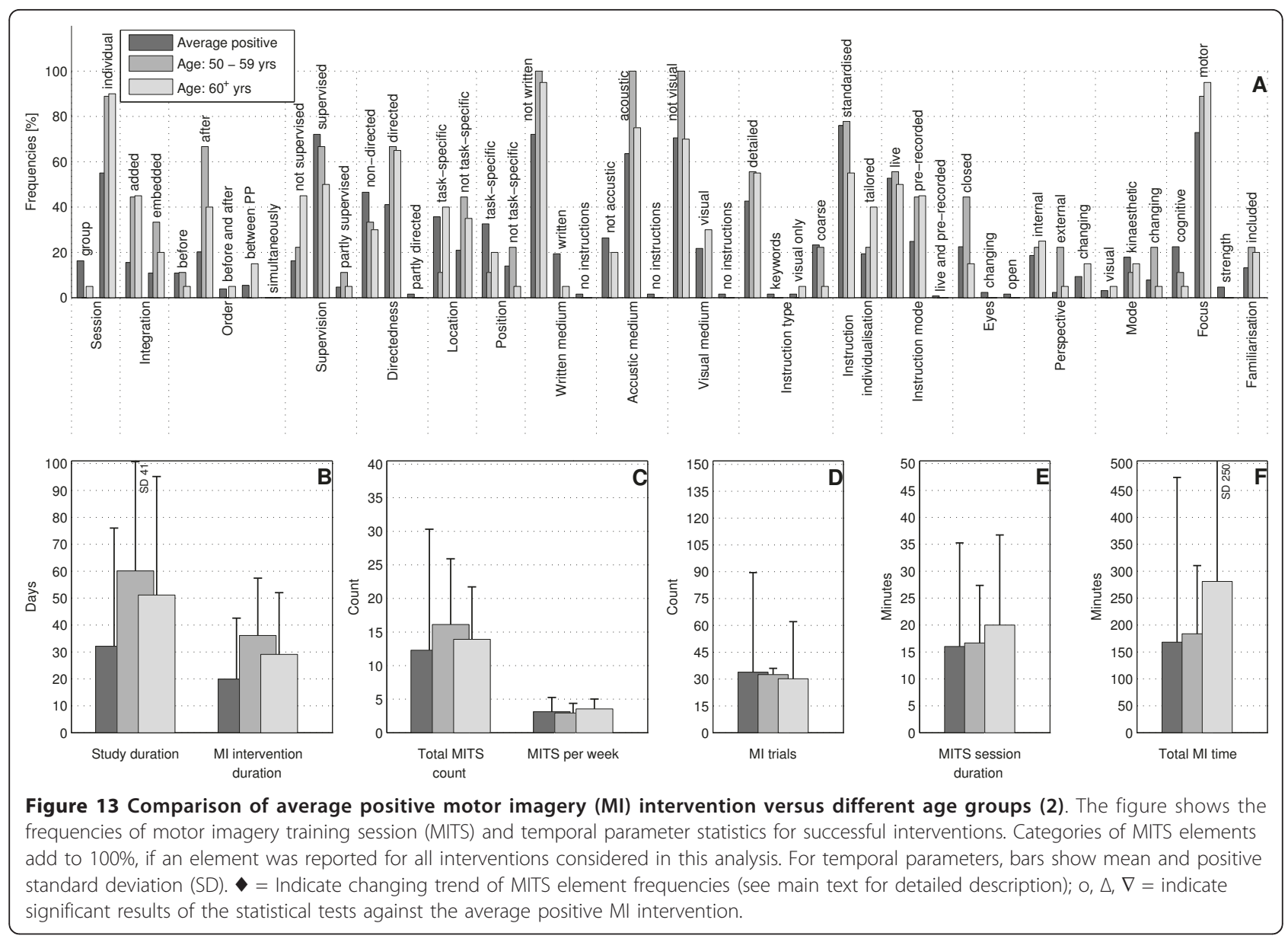

recovery breaks during an intensive training day in Sports.

In the current review, the positive MI interventions were mainly performed after PP. This result stands in contrast to the reported order of performing MI trials before PP in the meta-analysis of Feltz and Landers and the investigation of Etnier and Landers [1,41]. No overall conclusion on the reported order could be derived because of its dependency on the aim of the MI training, such as the learning of a new motor task, its adaptation, preparation for performance of a known motor task, achievement of peak performance, and memorisation of performance aspects.

Temporal parameters varied between disciplines. The longest study and MI intervention durations and the highest total number of MITS were seen in Medicine and Sports. Some of these variations could be explained by their very nature. For example, in Medicine, time to learn and perform the MI was required, reflecting system impairments, older age of the participants and chronic pain, whereas in Sports, MITS can be part of the daily training routine. The longest MITS duration could be found in Music, reflecting the length of the music pieces that were imagined. Medicine and Psychology had the highest numbers of MI trials per MITS. This supports the hypothesis that MI is effective in these fields when the imagined movement is short and simple (for example, one limb movement) to perform, with as many repetitions as possible during a short concentration period, as described above in the section on MI intervention outcome.

\section{MI session type}

The decision to implement MITS as group or individual sessions does not depend on the MI integration approach. Both group and individual sessions included added and embedded MITS. Both classifications were used in positive MI interventions during the entire publication period analysed. The MI intervention duration was longer for group MITS and shorter for individual MITS compared with the positive MITS. We hypothesised that the selection of session type was based rather on practical considerations than on scientific reasoning. Further research is needed to evaluate the influence of session type on the effectiveness of MI interventions. 


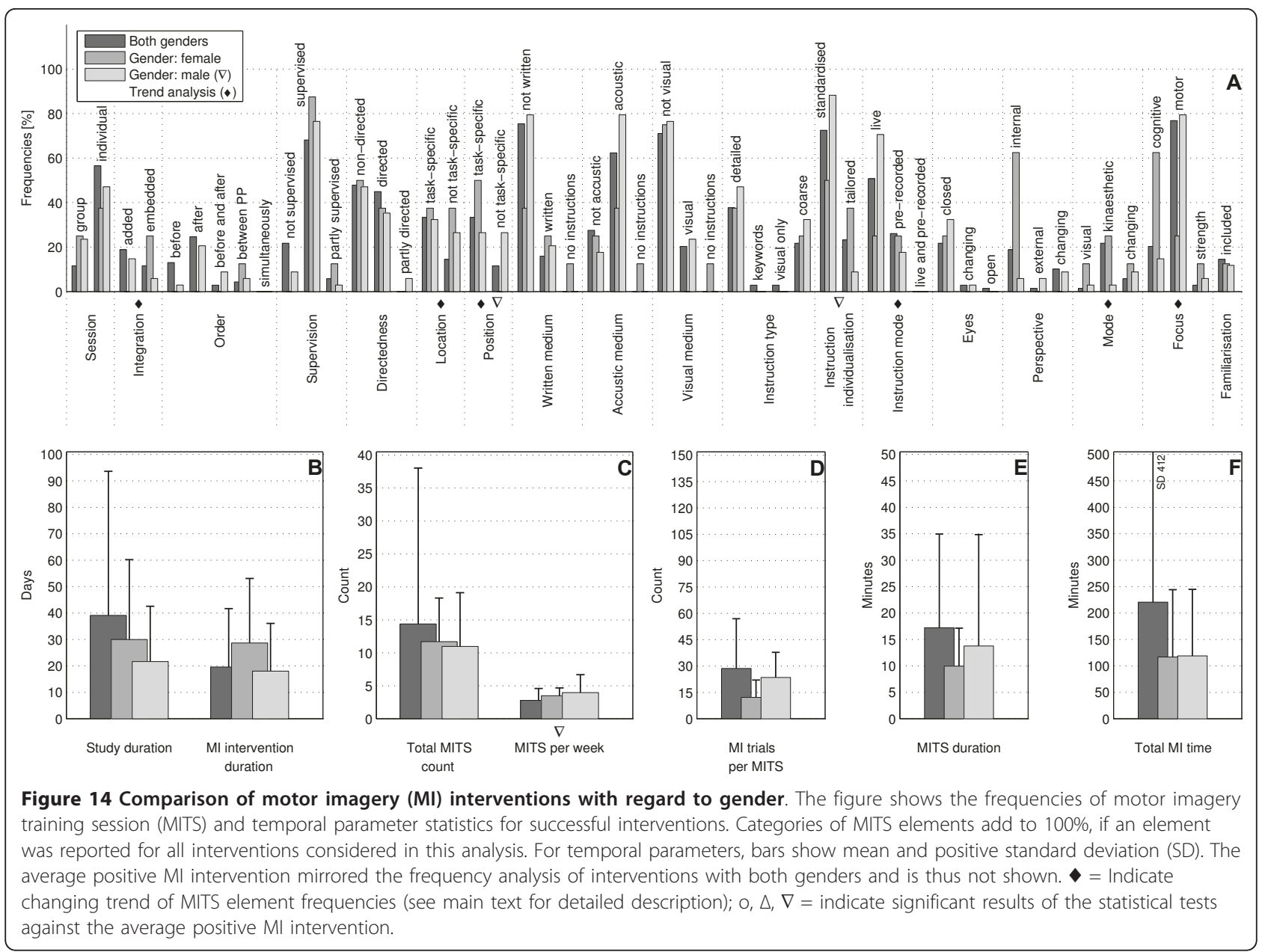

\section{Age groups}

Most MI interventions were performed with healthy students and young adults aged 20 to 29 years old. Hence there is a need for MI techniques and investigation of their effectiveness in young children and middle-aged adults, for which only a few references were found. Jarus and Ratzon reported that children aged 9 years and older adults aged 65 and 70 years benefited more from the combination of MI and PP than did young adults aged 21 to 40 years [42]. The full potential of MI in younger and older participants has not yet been sufficiently investigated, as evidenced by the low number of MI investigations found in these age groups.

\section{Gender effect}

In the current review gender differences were found in the chosen MITS elements. The results obtained will add to the ongoing debate on gender-dependent MI intervention design. Is it believed that males are better imagers than females, because of the different brain area activation and inhibition [43]. The 'bottom-up neural strategy' found in the work of Butler et al. could be related to the visuospatial performance benefit of men, with larger improvements for men gained from a motor-focused MI intervention compared with women [43]. This hypothesis could have influenced the MI intervention design in studies with female participants, which used mainly cognitive-focused tasks. However, a questionnaire survey given to healthy participants aged 18 to 65 years [44] did not confirm a gender imbalance on imagery usage. Furthermore, Lutz et al. did not detect a gender effect among high- and low-skilled golfers in a putting task after MI [45], nor were gender differences found in an investigation with two widely used imagery questionnaires [46]. In the current review, the study imbalance for female to male participants is 1 to 4.25. Therefore, we hope our analyses will prompt researchers to further explore potential gender differences in, for example, MI ability.

\section{Methodological considerations}

The only available MeSH term for searches was 'mental imagery', which must be considered as an umbrella term for various mental techniques. MI is one technique focusing on movements, which is important in 


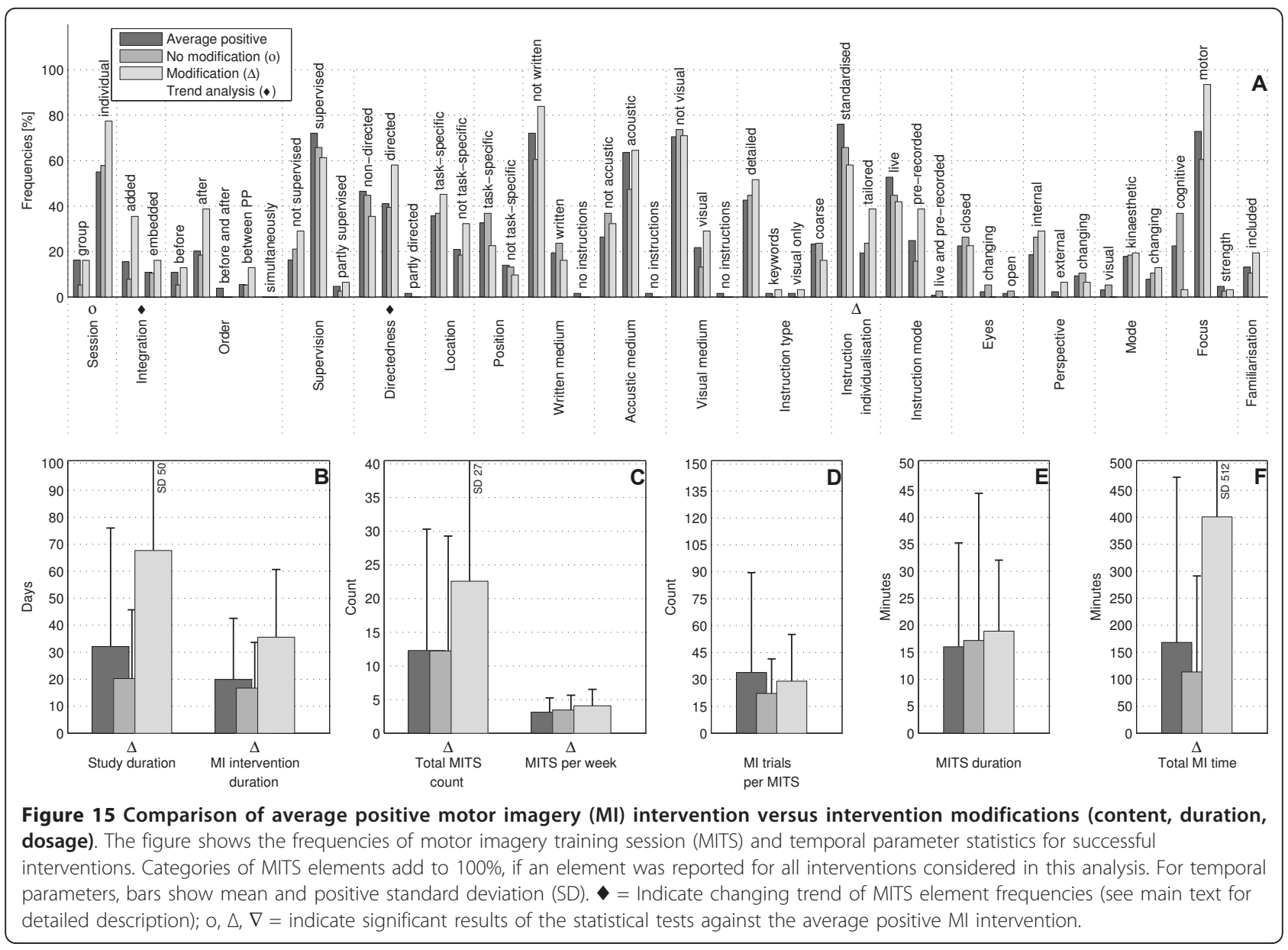

rehabilitation medicine. Historically, other terms have been used for the same purpose in literature. Our literature search included various terms associated with imagery, yielding a large initial reference count.

Studies were included regardless of their study design, country and year of publication. This method enabled us to obtain a global view of the MI literature in different disciplines and of the MI approaches that were evaluated in different study designs. We used and adapted two widely accepted scales to evaluate all studies for their methodological quality.

The analysed studies primarily investigated the shortterm effect of MI with a simple pre-/post-test design. The longest time period evaluated was a 6-month follow-up in an RCT by Moseley et al., in which significant improvements were seen in the MI treatment group compared with a control group [47].

Overall, data reporting in the selected articles was low, and the implications of this are highlighted by one of the least reported elements: imagery perspective. Depending on the chosen perspective (first or third person), different brain areas will be activated [48]. Publications on successful and non-successful athletes reported contradictory results for the imagery perspectives used $[46,49,50]$. Furthermore, Kim et al. investigated the exercise-related imagery perspective in middle-aged adults and, reported an internal:external perspective ratio of 1.8 [51]. Mulder et al. found a slightly better MI vividness in adults over 64 years when using the external MI perspective. The authors also mentioned that MI from an internal perspective is more important than MI from an external perspective in learning a motor skill $[52,53]$. Furthermore, they could detect a shift in perspective related to age, with younger people more likely to use the internal perspective and older people more likely to use the external perspective. Taking imagery perspective as an example, future research should detail MITS elements more carefully.

\section{Limitations and outlook}

There were two important sources of possible information bias: firstly, 51 references were not obtainable, and secondly, our selected references included only $12 \mathrm{MI}$ interventions with no change or negative results versus $129 \mathrm{MI}$ interventions with positive results. We therefore hypothesised that MI interventions without positive 
Table 3 Overview of extracted descriptive study data for the discipline Education

\begin{tabular}{|c|c|c|c|c|c|c|c|c|c|c|c|c|c|c|c|c|c|c|c|}
\hline \multirow[t]{2}{*}{ Reference } & \multirow[t]{2}{*}{ First author } & \multirow[t]{2}{*}{ Year } & \multirow[t]{2}{*}{ Country $^{a}$} & \multirow[t]{2}{*}{ Language } & \multirow{2}{*}{$\begin{array}{l}\text { Study } \\
\text { duration, } \\
\text { days }\end{array}$} & \multirow{2}{*}{$\begin{array}{c}\text { Intervention } \\
\text { duration, } \\
\text { days }\end{array}$} & \multirow{2}{*}{$\begin{array}{l}\text { Study } \\
\text { design }\end{array}$} & \multirow{2}{*}{$\begin{array}{l}\text { Study } \\
\text { groups }\end{array}$} & \multirow{2}{*}{$\begin{array}{l}\text { Number of } \\
\text { participants }\end{array}$} & \multirow[t]{2}{*}{ Participants } & \multirow[t]{2}{*}{ Gender } & \multirow[t]{2}{*}{ Age, years } & \multirow{2}{*}{$\begin{array}{l}\text { Body } \\
\text { part }\end{array}$} & \multirow[t]{2}{*}{ Training task } & \multirow[t]{2}{*}{ Focus } & \multirow{2}{*}{$\begin{array}{l}\text { Measurement } \\
\text { events }\end{array}$} & \multicolumn{2}{|c|}{ Results $^{b}$} & \multirow{2}{*}{$\begin{array}{l}\text { Quality } \\
\text { rating }\end{array}$} \\
\hline & & & & & & & & & & & & & & & & & $\begin{array}{l}\begin{array}{l}\text { Relative } \\
\text { change }\end{array}\end{array}$ & $\begin{array}{l}\text { Absolute } \\
\text { change }\end{array}$ & \\
\hline [93] & Bucher, L & 1993 & USA & English & 999 & 999 & RCT & 3 & 108 & $\begin{array}{l}\text { Nursing } \\
\text { students }\end{array}$ & NSt & $\begin{array}{l}\text { Range } \\
19 \text { to } 21\end{array}$ & $\begin{array}{l}\text { Upper } \\
\text { limb }\end{array}$ & $\begin{array}{l}\text { Remove sterile } \\
\text { gloves }\end{array}$ & M & 1 (post-test) & x & x & $5 / 10$ \\
\hline
\end{tabular}

\begin{tabular}{|c|c|c|c|c|c|c|c|c|c|c|c|c|c|c|c|c|c|c|c|}
\hline [93] & Bucher, L & 1993 & USA & English & 999 & 999 & RCT & 3 & 108 & $\begin{array}{l}\text { Nursing } \\
\text { students }\end{array}$ & NSt & $\begin{array}{l}\text { Range } \\
19 \text { to } 21\end{array}$ & $\begin{array}{l}\text { Upper } \\
\text { limb }\end{array}$ & $\begin{array}{c}\text { Remove sterile } \\
\text { gloves }\end{array}$ & M & 1 (post-test) & $x$ & $r$ & $5 / 10$ \\
\hline [94] & Doheny, MO & 1993 & USA & English & 1 & 1 & RCT & 4 & 95 & $\begin{array}{l}\text { Nursing } \\
\text { students }\end{array}$ & Both & $\begin{array}{l}\text { Mean }=21 \\
\text { range } \\
18 \text { to } 40\end{array}$ & $\begin{array}{l}\text { Upper } \\
\text { limb }\end{array}$ & $\begin{array}{l}\text { Intramuscular } \\
\text { injection }\end{array}$ & M & 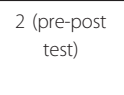 & $\rightarrow$ & NSt & $5 / 10$ \\
\hline [95] & Immenroth, M & 2005 & $\mathrm{DE}$ & English & 2 & 1 & $\mathrm{RCT}$ & 3 & 98 & Surgeons & NSt & $\begin{array}{c}\text { Mean } \pm \\
\mathrm{SD}=32 \pm 4\end{array}$ & $\begin{array}{l}\text { Upper } \\
\text { limb }\end{array}$ & $\begin{array}{l}\text { Laparoscopic } \\
\text { cholecystectomy }\end{array}$ & M & $\begin{array}{c}2 \text { (pre-post } \\
\text { test) }\end{array}$ & $x$ & $>$ & $9 / 10$ \\
\hline [96] & Komesu & 2009 & USA & English & 999 & 1 & $\mathrm{RCT}$ & 2 & 68 & Surgeons & NSt & NSt & $\begin{array}{l}\text { Upper } \\
\text { limb }\end{array}$ & Surgical cystoscopy & c & 1 (post-test) & $x$ & $x$ & $8 / 10$ \\
\hline [97] & Sanders, CW & 2004 & USA & English & 21 & 21 & $\mathrm{RCT}$ & 3 & 65 & $\begin{array}{l}\text { Medical } \\
\text { students }\end{array}$ & NSt & Students & $\begin{array}{l}\text { Upper } \\
\text { limb }\end{array}$ & $\begin{array}{l}\text { Basic surgical } \\
\text { procedures }\end{array}$ & M & $\begin{array}{c}2 \text { (pre-post } \\
\text { test) }\end{array}$ & $\rightarrow$ & 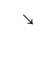 & $7 / 10$ \\
\hline [98] & Sanders & 2008 & USA & English & 15 & 2 & RCT & 2 & 64 & $\begin{array}{l}\text { Medical } \\
\text { students }\end{array}$ & NSt & NSt & $\begin{array}{l}\text { Upper } \\
\text { limb }\end{array}$ & $\begin{array}{l}\text { Basic surgical } \\
\text { procedures }\end{array}$ & c & $\begin{array}{l}3 \text { (post-tests, } \\
\text { FU) }\end{array}$ & $x$ & $x$ & $9 / 10$ \\
\hline [99] & Stig, LC & 1989 & UK & English & 1 & 1 & RCT & 2 & 35 & $\begin{array}{l}\text { Chiropractic } \\
\text { students }\end{array}$ & Both & $\begin{array}{c}\text { Mean }=23, \\
\text { range } \\
19 \text { to } 40\end{array}$ & $\begin{array}{l}\text { Upper } \\
\text { limb }\end{array}$ & $\begin{array}{c}\text { Chiropractic } \\
\text { adjustment skill }\end{array}$ & M & $\begin{array}{c}2 \text { (pre-post } \\
\text { test) }\end{array}$ & $\rightarrow$ & ${ }^{x}$ & $6 / 10$ \\
\hline [100] & Welk, A & 2007 & DE & English & 999 & 999 & RCT & 2 & 41 & $\begin{array}{l}\text { Dentistry } \\
\text { students }\end{array}$ & Both & Mean $=23$ & $\begin{array}{l}\text { Upper } \\
\text { limb }\end{array}$ & $\begin{array}{l}\text { Preparation of tooth } \\
\text { crown }\end{array}$ & c & $\begin{array}{c}2 \text { (pre-post } \\
\text { test) }\end{array}$ & 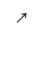 & $r$ & $8 / 10$ \\
\hline [60] & Wright, CJ & 2008 & UK & English & 999 & 28 & RCT & 2 & 56 & Students & Both & $\begin{array}{l}\text { University } \\
\text { Students }\end{array}$ & $\begin{array}{l}\text { Upper } \\
\text { limb }\end{array}$ & $\begin{array}{l}\text { Measuring blood } \\
\text { pressure, antiseptic } \\
\text { dressing task }\end{array}$ & c & $\begin{array}{c}2 \text { (pre-post } \\
\text { test) }\end{array}$ & $x$ & $r$ & $8 / 10$ \\
\hline
\end{tabular}

a Countries: AU = Australia, BE = Belgium, BR = Brazil, CA = Canada, DE = Germany, ES = Spain, FR = France, G = German, GR = Greece, HK = Hong Kong, IL = Israel, IR = Iran, IT = Italy, KR = South Korea, NL = The Netherlands, NZ = New Zealand, PT = Portugal, SE = Sweden, UK = United Kingdom, USA = United States of America.

${ }^{\text {b}}$ Two elements were used to describe the study results: relative and absolute change: relative change evaluates the Ml group results versus results of other study groups, while absolute change indicates the change of the Ml group from pre- to post-test. $\lambda_{1} \rightarrow, \lambda=$ indicate trends of the study results from pre- to post-test ( $\nearrow$ positive change, $\rightarrow-$ no change, $>-$ negative change, $\approx=$ no precise numbers of measurement events stated in the publication)

Abbreviations: $\mathrm{BL}=$ Baseline, $\mathrm{C}=$ cognitive, $\mathrm{CG}=$ control group, $\mathrm{CRPS1}=$ complex regional pain syndrome type 1 , int. $=$ Intervention, $\mathrm{M}=$ motor, $\mathrm{N} / \mathrm{A}=$ not applicable, NK, not known; NSt $=$ not stated, $\mathrm{S}=$ strength 
Table 4 Overview of extracted descriptive study data for the discipline Medicine

\begin{tabular}{|c|c|c|c|c|c|c|c|c|c|c|c|c|c|c|c|c|c|c|c|}
\hline \multirow[t]{2}{*}{ Reference } & \multirow[t]{2}{*}{ First author } & \multirow[t]{2}{*}{ Year } & \multirow[t]{2}{*}{ Country } & \multirow[t]{2}{*}{ Language } & \multirow{2}{*}{$\begin{array}{l}\text { Study } \\
\text { duration, } \\
\text { days }\end{array}$} & \multirow{2}{*}{$\begin{array}{l}\text { Intervention } \\
\text { duration, } \\
\text { days }\end{array}$} & \multirow{2}{*}{$\begin{array}{l}\text { Study } \\
\text { design }\end{array}$} & \multirow{2}{*}{$\begin{array}{l}\text { Study } \\
\text { groups }\end{array}$} & \multirow{2}{*}{$\begin{array}{l}\text { Number of } \\
\text { participants }\end{array}$} & \multirow[t]{2}{*}{ Participants } & \multirow[t]{2}{*}{ Gender } & \multirow[t]{2}{*}{ Age, years } & \multirow[t]{2}{*}{ Body part } & \multirow{2}{*}{$\begin{array}{l}\text { Training } \\
\text { task }\end{array}$} & \multirow[t]{2}{*}{ Focus } & \multirow{2}{*}{$\begin{array}{l}\text { Measurement } \\
\text { events }\end{array}$} & \multicolumn{2}{|c|}{ Results } & \multirow{2}{*}{$\begin{array}{l}\text { Quality } \\
\text { rating }\end{array}$} \\
\hline & & & & & & & & & & & & & & & & & $\begin{array}{l}\text { Relative } \\
\text { change }\end{array}$ & $\begin{array}{l}\text { Absolute } \\
\text { change }\end{array}$ & \\
\hline [84] & $\begin{array}{l}\text { Bovend'Eerdt, } \\
\text { TJH }\end{array}$ & 2009 & UK & $E$ & 999 & 56 & RCT & 2 & 11 & $\begin{array}{l}\text { Stroke, MS, } \\
\text { TBI }\end{array}$ & Both & $\begin{array}{l}\text { Mean } \pm \\
\mathrm{SD}= \\
50 \pm 14\end{array}$ & $\begin{array}{l}\text { Whole } \\
\text { body }\end{array}$ & $\begin{array}{l}\text { Muscle } \\
\text { stretching }\end{array}$ & $M$ & $\begin{array}{l}2 \text { (pre- } \\
\text { post-test) }\end{array}$ & $\rightarrow$ & $\rightarrow$ & $7 / 10$ \\
\hline [58] & $\begin{array}{l}\text { Bovend'Eerdt, } \\
\text { TJH }\end{array}$ & 2010 & UK & $E$ & 126 & 35 & RCT & 2 & 30 & $\begin{array}{l}\text { Stroke, TBI, } \\
\text { MS }\end{array}$ & Both & $\begin{array}{l}\text { Mean } \pm \\
S D= \\
50 \pm 14\end{array}$ & $\begin{array}{l}\text { Lower } \\
\text { limb }\end{array}$ & ADL tasks & $M$ & $\begin{array}{l}3 \text { (pre- } \\
\text { post-test, FU) }\end{array}$ & $\rightarrow$ & $\pi$ & $8 / 10$ \\
\hline [101] & Cramer, SC & 2007 & USA & $E$ & 9 & 7 & CS & $\mathrm{N} / \mathrm{A}$ & 20 & $\mathrm{SCl}$ & NSt & $\begin{array}{l}\text { Mean } \pm \\
\mathrm{SD}= \\
31 \pm 4\end{array}$ & $\begin{array}{l}\text { Tongue, } \\
\text { foot }\end{array}$ & Tapping & M & $\begin{array}{l}2 \text { (pre- } \\
\text { post-test) }\end{array}$ & N/A & 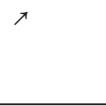 & 9/11 \\
\hline [102] & Crosbie, J & 2004 & UK & $\mathrm{E}$ & 35 & 14 & SCRD & $\mathrm{N} / \mathrm{A}$ & 10 & Stroke & Both & $\begin{array}{l}\text { Range } 45 \\
\text { to } 81\end{array}$ & $\begin{array}{l}\text { Upper } \\
\text { limb }\end{array}$ & $\begin{array}{l}\text { Reaching, } \\
\text { grasping }\end{array}$ & M & $\begin{array}{l}10 \text { (BL, during } \\
\text { int., FU) }\end{array}$ & $\mathrm{N} / \mathrm{A}$ & $\pi$ & 10/11 \\
\hline [59] & Dickstein, $\mathrm{R}$ & 2004 & $\mathrm{IL}$ & $E$ & 42 & 42 & SCRD & $\mathrm{N} / \mathrm{A}$ & 1 & Stroke & Male & 69 & $\begin{array}{l}\text { Lower } \\
\text { limb }\end{array}$ & Walking & $M$ & $\begin{array}{l}5 \text { (BL, midterm, } \\
\text { post-test, FU) }\end{array}$ & $\mathrm{N} / \mathrm{A}$ & $\pi$ & $9 / 11$ \\
\hline [103] & Dijkerman, R & 2004 & UK & $E$ & 28 & 28 & CCT & 3 & 20 & Stroke & Both & $\begin{array}{l}\text { Mean } \pm \\
S D= \\
64 \pm 9\end{array}$ & $\begin{array}{l}\text { Upper } \\
\text { limb }\end{array}$ & $\begin{array}{l}\text { Reaching, } \\
\text { grasping }\end{array}$ & M & $\begin{array}{l}2 \text { (pre- } \\
\text { post-test) }\end{array}$ & $\pi$ & $\pi$ & $5 / 10$ \\
\hline [104] & Dunsky, A & 2006 & $\mathrm{IL}$ & $E$ & 77 & 42 & SCRD & $\mathrm{N} / \mathrm{A}$ & 4 & Stroke & Male & $\begin{array}{l}\text { Mean }= \\
58,(64,57, \\
63,47)\end{array}$ & $\begin{array}{l}\text { Lower } \\
\text { limb }\end{array}$ & Walking & M & $\begin{array}{l}5 \text { (BL, midterm, } \\
\text { post-test, FU) }\end{array}$ & $\mathrm{N} / \mathrm{A}$ & $\nearrow$ & 9/11 \\
\hline [105] & Dunsky, A & 2008 & $\mathrm{IL}$ & $E$ & 77 & 21 & CS & $\mathrm{N} / \mathrm{A}$ & 17 & Stroke & Both & Mean $=58$ & $\begin{array}{l}\text { Lower } \\
\text { limb }\end{array}$ & Walking & $M$ & $\begin{array}{l}6 \text { (BL, pre-test, } \\
\text { during int., } \\
\text { post-test, FU) }\end{array}$ & $\mathrm{N} / \mathrm{A}$ & $\pi$ & $11 / 11$ \\
\hline [38] & Guillot, A & 2009 & $F R$ & $E$ & 14 & 999 & RCT & 2 & 14 & hand burn & Both & $\begin{array}{l}\text { Mean } \pm \\
\mathrm{SD}=47 \pm \\
14, \text { range } \\
27 \text { to } 74\end{array}$ & $\begin{array}{l}\text { Upper } \\
\text { limb }\end{array}$ & $\begin{array}{l}\text { Wrist }+ \\
\text { finger } \\
\text { movements }\end{array}$ & M & $\begin{array}{l}\approx 6 \text { (pre-test, } \\
\text { during int., } \\
\text { post-test) }\end{array}$ & $\nearrow$ & $\pi$ & 7/10 \\
\hline [106] & Gustin, SM & 2008 & $\mathrm{AU}$ & $\mathrm{E}$ & 15 & 7 & CS & $\mathrm{N} / \mathrm{A}$ & 15 & $\mathrm{SCl}$ & Male & $\begin{array}{l}\text { Mean }= \\
47, \text { range } \\
26 \text { to } 67\end{array}$ & $\begin{array}{l}\text { Lower } \\
\text { limb }\end{array}$ & $\begin{array}{l}\text { Plantarflexion, } \\
\text { dorsiflexion }\end{array}$ & M & $\begin{array}{l}2 \text { (pre- } \\
\text { post-test) }\end{array}$ & N/A & $y$ & $8 / 11$ \\
\hline [107] & Hewett, T & 2007 & USA & $E$ & 56 & 42 & SCRD & $\mathrm{N} / \mathrm{A}$ & 5 & Stroke & Both & $\begin{array}{l}\text { Mean }= \\
53 \pm 5 \\
\text { range } 38 \\
\text { to } 76\end{array}$ & $\begin{array}{l}\text { Upper } \\
\text { limb }\end{array}$ & $\begin{array}{l}\text { Reaching, } \\
\text { grasping }\end{array}$ & M & $\begin{array}{l}2 \text { (pre- } \\
\text { post-test) }\end{array}$ & N/A & $\lambda$ & $7 / 11$ \\
\hline [108] & Jackson, PL & 2004 & $C A$ & $\mathrm{E}$ & 35 & 21 & SCRD & $\mathrm{N} / \mathrm{A}$ & 1 & $\begin{array}{l}\text { Hemorrhage- } \\
\text { related lesion }\end{array}$ & Male & 38 & $\begin{array}{l}\text { Lower } \\
\text { limb }\end{array}$ & $\begin{array}{l}\text { Foot serial } \\
\text { response } \\
\text { time task }\end{array}$ & M & $\begin{array}{l}2 \text { (pre- } \\
\text { post-test) }\end{array}$ & $\mathrm{N} / \mathrm{A}$ & $\nearrow$ & $8 / 11$ \\
\hline [109] & Liu, K & 2004 & $\mathrm{HK}$ & $E$ & 21 & 21 & RCT & 2 & 46 & Stroke & Both & Mean $=72$ & $\begin{array}{l}\text { Whole } \\
\text { body }\end{array}$ & ADL tasks & M & $\begin{array}{l}3 \text { (pre-post- } \\
\text { test, FU) }\end{array}$ & $\pi$ & $\pi$ & 7/10 \\
\hline [110] & Liu, K & 2004 & HK & $\mathrm{E}$ & 49 & 14 & SCRD & $\mathrm{N} / \mathrm{A}$ & 2 & Stroke & Both & 65,66 & $\begin{array}{l}\text { Whole } \\
\text { body }\end{array}$ & ADL tasks & M & $\begin{array}{l}3 \text { (pre-post- } \\
\text { test, FU) }\end{array}$ & $\mathrm{N} / \mathrm{A}$ & 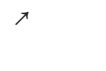 & $7 / 11$ \\
\hline
\end{tabular}


Table 4 Overview of extracted descriptive study data for the discipline Medicine (Continued)

\begin{tabular}{|c|c|c|c|c|c|c|c|c|c|c|c|c|c|c|c|c|c|c|c|}
\hline [111] & Liu, KPY & 2009 & HK & $E$ & 999 & 2 & RCT & 2 & 33 & Stroke & Both & $\begin{array}{l}\text { Mean }= \\
70 \pm 8\end{array}$ & $\begin{array}{l}\text { Whole } \\
\text { body }\end{array}$ & ADL tasks & $M$ & 2 (pre-post-test) & $\pi$ & $\pi$ & $8 / 10$ \\
\hline [62] & Malouin, F & 2004 & CA & $E$ & 2 & 1 & CS & N/A & 12 & Stroke & Both & $\begin{array}{l}\text { Mean }= \\
53 \pm 12\end{array}$ & $\begin{array}{l}\text { Lower } \\
\text { limb }\end{array}$ & $\begin{array}{l}\text { Symmetrical } \\
\text { load } \\
\text { standing } \\
\text { up }+ \text { sitting } \\
\text { down }\end{array}$ & $M$ & $\begin{array}{l}3 \text { (pre-post- } \\
\text { test, FU) }\end{array}$ & N/A & $\pi$ & $9 / 11$ \\
\hline [63] & Malouin, F & 2009 & CA & $E$ & 42 & 21 & RCT & 3 & 12 & Stroke & Both & $\begin{array}{l}\text { Mean }= \\
61 \pm 8, \\
\text { range } 53 \\
\text { to } 75\end{array}$ & $\begin{array}{l}\text { Lower } \\
\text { limb }\end{array}$ & $\begin{array}{l}\text { Symmetrical } \\
\text { load } \\
\text { standing } \\
\text { up }+ \text { sitting } \\
\text { down }\end{array}$ & $M$ & $\begin{array}{l}3 \text { (pre-post- } \\
\text { test, FU) }\end{array}$ & $\pi$ & $\pi$ & $8 / 10$ \\
\hline [112] & McCarthy, M & 2002 & UK & $E$ & 999 & 999 & SCRD & N/A & 2 & CVA, TBI & Male & 64,36 & & Neglect & M & $\begin{array}{l}3 \text { (pre-test, } \\
\text { during int., } \\
\text { post-test) }\end{array}$ & N/A & $\lambda$ & $9 / 11$ \\
\hline [113] & Moseley, GL & 2004 & $\mathrm{AU}$ & $E$ & 210 & 14 & RCT & 2 & 13 & $\begin{array}{l}\text { CRPS1 after } \\
\text { wrist fracture }\end{array}$ & Both & $\begin{array}{l}\text { Mean } \pm \\
\mathrm{SD}= \\
37 \pm 15\end{array}$ & $\begin{array}{l}\text { Upper } \\
\text { limb }\end{array}$ & $\begin{array}{l}\text { Hand }+ \\
\text { finger } \\
\text { movements }\end{array}$ & M & $\begin{array}{l}5 \text { (pre-test, } \\
\text { during int., } \\
\text { post-test, FU) }\end{array}$ & 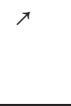 & $\nearrow$ & $7 / 10$ \\
\hline [114] & Moseley, GL & 2005 & $\mathrm{AU}$ & $E$ & 126 & 14 & RCT & 3 & 20 & $\begin{array}{l}\text { CRPS1 after } \\
\text { wrist fracture }\end{array}$ & Both & $\begin{array}{l}\text { Mean }= \\
34 \pm 8\end{array}$ & $\begin{array}{l}\text { Upper } \\
\text { limb }\end{array}$ & $\begin{array}{l}\text { Hand }+ \\
\text { finger } \\
\text { movements }\end{array}$ & $M$ & $\begin{array}{l}5 \text { (pre-test, } \\
\text { during int., } \\
\text { post-test, FU) }\end{array}$ & $\pi$ & $\pi$ & $7 / 10$ \\
\hline$[47]$ & Moseley, GL & 2006 & $\mathrm{AU}$ & $E$ & 84 & 14 & RCT & 2 & 51 & $\begin{array}{l}\text { Phantom } \\
\text { limb, CRPS1 }\end{array}$ & Both & 37 & $\begin{array}{l}\text { Upper } \\
\text { limb }\end{array}$ & $\begin{array}{l}\text { Hand }+ \\
\text { finger } \\
\text { movements }\end{array}$ & M & $\begin{array}{l}3 \text { (pre- } \\
\text { post-test, FU) }\end{array}$ & $\nearrow$ & $\nearrow$ & $7 / 10$ \\
\hline [86] & Moseley, GL & 2008 & $\begin{array}{l}\text { Western } \\
\text { Europe } \\
+\mathrm{AU}\end{array}$ & $E$ & 1 & 1 & $\mathrm{CCT}$ & 2 & 37 & $\begin{array}{l}\text { CRPS1, no- } \\
\text { CRPS1 pain }\end{array}$ & Both & $\begin{array}{l}\text { Mean } \pm \\
S D= \\
41 \pm 14\end{array}$ & $\begin{array}{l}\text { Upper } \\
\text { limb }\end{array}$ & $\begin{array}{l}\text { Hand }+ \\
\text { finger } \\
\text { movements }\end{array}$ & $M$ & $\begin{array}{l}2 \text { (pre- } \\
\text { post-test) }\end{array}$ & $\rightarrow$ & $y$ & $5 / 10$ \\
\hline [115] & Mueller, K & 2007 & $\mathrm{DE}$ & $E$ & 98 & 28 & $\mathrm{RCT}$ & 3 & 17 & Stroke & Both & $\begin{array}{l}\text { Mean } \pm \\
S D= \\
62 \pm 10\end{array}$ & $\begin{array}{l}\text { Upper } \\
\text { limb }\end{array}$ & $\begin{array}{l}\text { Finger+hand } \\
\text { movements }\end{array}$ & M & $\begin{array}{l}8 \text { (BL, during } \\
\text { int., post-test, } \\
\text { FU) }\end{array}$ & $\rightarrow$ & $\lambda$ & $6 / 10$ \\
\hline [116] & Page, SJ & 2000 & USA & $E$ & 28 & 28 & $\mathrm{RCT}$ & 2 & 16 & Stroke & Male & $\begin{array}{l}\text { Mean }= \\
63\end{array}$ & $\begin{array}{l}\text { Upper } \\
\text { limb }\end{array}$ & & & $\begin{array}{l}\text { Weightbearing } \\
+ \text { functional } \\
\text { task }\end{array}$ & M & $\begin{array}{l}2 \text { (pre- } \\
\text { post- } \\
\text { test) }\end{array}$ & $\pi$ \\
\hline$x$ & $7 / 10$ & & & & & & & & & & & & & & & & & & \\
\hline [65] & Page, SJ & 2001 & USA & $\mathrm{E}$ & 56 & 42 & SCRD & N/A & 1 & Stroke & Male & 56 & $\begin{array}{l}\text { Upper } \\
\text { limb }\end{array}$ & $\begin{array}{l}\text { Whole arm } \\
\text { movements }\end{array}$ & M & $\begin{array}{l}3 \text { (BL, } \\
\text { post-test) }\end{array}$ & N/A & $\pi$ & 7/11 \\
\hline [64] & Page, SJ & 2001 & USA & $E$ & 56 & 42 & $\mathrm{RCT}$ & 2 & 13 & Stroke & Both & $\begin{array}{l}\text { Mean } \pm \\
\mathrm{SD}=65 \\
\text { range } 64 \\
\text { to } 79\end{array}$ & $\begin{array}{l}\text { Upper } \\
\text { limb }\end{array}$ & $\begin{array}{l}\text { Whole arm } \\
\text { movements }\end{array}$ & $M$ & $\begin{array}{l}3 \text { (BL, } \\
\text { post-test) }\end{array}$ & $\pi$ & $\pi$ & $7 / 10$ \\
\hline [117] & Page, SJ & 2005 & USA & $E$ & 56 & 42 & RCT & 2 & 11 & Stroke & Both & $\begin{array}{l}\text { Mean = } \\
62 \pm 5 \\
\text { range } 53 \\
\text { to } 71\end{array}$ & $\begin{array}{l}\text { Upper } \\
\text { limb }\end{array}$ & $\begin{array}{l}\text { Hand ADL } \\
\text { tasks }\end{array}$ & $M$ & $\begin{array}{l}3 \text { (BL, } \\
\text { post-test) }\end{array}$ & $\pi$ & $\pi$ & $8 / 10$ \\
\hline
\end{tabular}


Table 4 Overview of extracted descriptive study data for the discipline Medicine (Continued)

\begin{tabular}{|c|c|c|c|c|c|c|c|c|c|c|c|c|c|c|c|c|c|c|c|}
\hline [118] & Page, SJ & 2007 & USA & $E$ & 999 & 72 & CS & N/A & 4 & Stroke & Both & $\begin{array}{l}\text { Mean }= \\
63, \text { range } \\
49 \text { to } 73\end{array}$ & $\begin{array}{l}\text { Upper } \\
\text { limb }\end{array}$ & $\begin{array}{l}\text { Hand ADL } \\
\text { tasks }\end{array}$ & $M$ & $\begin{array}{l}2 \text { (pre- } \\
\text { post-test) }\end{array}$ & N/A & $\pi$ & $10 / 11$ \\
\hline [119] & Page, SJ & 2007 & USA & $E$ & 63 & 42 & RCT & 2 & 32 & Stroke & NSt & $\begin{array}{l}\text { Mean } \pm \\
S D= \\
60 \pm 14\end{array}$ & $\begin{array}{l}\text { Upper } \\
\text { limb }\end{array}$ & $\begin{array}{l}\text { Hand ADL } \\
\text { tasks }\end{array}$ & $M$ & $\begin{array}{l}3 \text { (BL, post- } \\
\text { test) }\end{array}$ & $\pi$ & $\pi$ & $8 / 10$ \\
\hline [120] & Page, SJ & 2009 & USA & $E$ & 91 & 70 & CS & $\mathrm{N} / \mathrm{A}$ & 10 & Stroke & Both & $\begin{array}{l}\text { Mean }= \\
57 \pm 12 \\
\text { range } 37 \\
\text { to } 69\end{array}$ & $\begin{array}{l}\text { Upper } \\
\text { limb }\end{array}$ & $\begin{array}{l}\text { Whole arm } \\
\text { ADL tasks }\end{array}$ & $M$ & $\begin{array}{l}3 \text { (BL, post-t } \\
\text { est) }\end{array}$ & N/A & $\pi$ & $9 / 11$ \\
\hline [121] & Page, SJ & 2009 & USA & $E$ & 168 & 70 & RCT & 2 & 10 & Stroke & Both & $\begin{array}{l}\text { Mean } \pm \\
\mathrm{SD}=61 \pm \\
3, \text { range } \\
48 \text { to } 79\end{array}$ & $\begin{array}{l}\text { Upper } \\
\text { limb }\end{array}$ & $\begin{array}{l}\text { Whole arm } \\
\text { ADL tasks }\end{array}$ & $M$ & $\begin{array}{l}4 \text { (BL, post- } \\
\text { test, FU) }\end{array}$ & $\pi$ & $\pi$ & $8 / 10$ \\
\hline [122] & Riccio, I & 2010 & IT & $E$ & 42 & 21 & RCT & 2 & 36 & Stroke & Both & $\begin{array}{l}\text { Mean }= \\
60 \pm 12\end{array}$ & $\begin{array}{l}\text { Upper } \\
\text { limb }\end{array}$ & $\begin{array}{l}\text { Whole arm } \\
\text { ADL tasks }\end{array}$ & $M$ & $\begin{array}{l}3 \text { (pre-test, } \\
\text { first + second } \\
\text { study part) }\end{array}$ & $\pi$ & $\pi$ & $8 / 10$ \\
\hline [123] & Simmons, L & 2008 & UK & $E$ & 999 & 10 & CS & CS & 10 & Stroke & Both & $\begin{array}{l}\text { Mean }= \\
68 \pm 14\end{array}$ & $\begin{array}{l}\text { Upper } \\
\text { limb }\end{array}$ & $\begin{array}{l}\text { Whole arm } \\
\text { movements }\end{array}$ & $M$ & $\begin{array}{l}3 \text { (pre- } \\
\text { post-test, FU) }\end{array}$ & N/A & $\pi$ & $7 / 11$ \\
\hline [66] & Stenekes, MW & 2009 & $\mathrm{NL}$ & $E$ & 84 & 42 & $\mathrm{RCT}$ & 2 & 25 & $\begin{array}{l}\text { Surgery for } \\
\text { carpal tunnel } \\
\text { syndrome }\end{array}$ & Both & $\begin{array}{l}\text { Mean } \pm \\
\mathrm{SD}= \\
34 \pm 11\end{array}$ & $\begin{array}{l}\text { Upper } \\
\operatorname{limb}\end{array}$ & $\begin{array}{l}\text { Passive } \\
\text { bending }+ \\
\text { straightening } \\
\text { wrist }+ \\
\text { fingers }\end{array}$ & M & $\begin{array}{l}3 \text { (pre- } \\
\text { post-test, FU) }\end{array}$ & 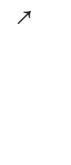 & $\pi$ & $7 / 10$ \\
\hline [124] & Stevens, JA & 2003 & USA & $E$ & 128 & 28 & SCRD & $\mathrm{N} / \mathrm{A}$ & 2 & Stroke & Both & $76 ; 63$ & $\begin{array}{l}\text { Upper } \\
\text { limb }\end{array}$ & $\begin{array}{l}\text { Wrist } \\
\text { movements, } \\
\text { object } \\
\text { manipulation }\end{array}$ & $M$ & $\begin{array}{l}4 \text { (pre-test, } \\
\text { during int., } \\
\text { post-test, FU) }\end{array}$ & N/A & $\pi$ & $7 / 11$ \\
\hline [125] & Tamir, R & 2007 & $\mathrm{IL}$ & $E$ & 84 & 84 & $\mathrm{RCT}$ & 2 & 23 & $\begin{array}{l}\text { Parkinson } \\
\text { disease }\end{array}$ & Both & $\begin{array}{l}\text { Mean } \pm \\
S D= \\
67 \pm 10\end{array}$ & $\begin{array}{l}\text { Whole } \\
\text { body }\end{array}$ & ADL tasks & $M$ & $\begin{array}{l}2 \text { (pre- } \\
\text { post-test) }\end{array}$ & $\pi$ & $\lambda$ & $7 / 10$ \\
\hline [126] & Yoo, EY & 2006 & KR & $E$ & 10 & 999 & SCRD & $\mathrm{N} / \mathrm{A}$ & 3 & Stroke & Male & $\begin{array}{l}\text { Mean = } \\
57,(46, \\
70,56)\end{array}$ & $\begin{array}{l}\text { Lower } \\
\text { limb }\end{array}$ & $\begin{array}{l}\text { Symmetrical } \\
\text { weight- } \\
\text { bearing }\end{array}$ & $M$ & $\begin{array}{l}21 \text { (BL, during } \\
\text { int., post- } \\
\text { test, FU) }\end{array}$ & N/A & $\pi$ & $9 / 11$ \\
\hline
\end{tabular}




\section{Table 5 Overview of extracted descriptive study data for the discipline Music}

\begin{tabular}{|c|c|c|c|c|c|c|c|c|c|c|c|c|c|c|c|c|c|c|c|}
\hline \multirow[t]{2}{*}{ Reference } & \multirow{2}{*}{$\begin{array}{l}\text { First } \\
\text { author }\end{array}$} & \multirow[t]{2}{*}{ Year } & \multirow[t]{2}{*}{ Country } & \multirow[t]{2}{*}{ Language } & \multirow{2}{*}{$\begin{array}{l}\text { Study } \\
\text { duration, } \\
\text { days }\end{array}$} & \multirow{2}{*}{$\begin{array}{l}\text { Intervention } \\
\text { duration, days }\end{array}$} & \multirow{2}{*}{$\begin{array}{l}\text { Study } \\
\text { design }\end{array}$} & \multirow{2}{*}{$\begin{array}{l}\text { Study } \\
\text { groups }\end{array}$} & \multirow{2}{*}{$\begin{array}{l}\text { Number of } \\
\text { participants }\end{array}$} & \multirow[t]{2}{*}{ Participants } & \multirow[t]{2}{*}{ Gender } & \multirow[t]{2}{*}{ Age, years } & \multirow{2}{*}{$\begin{array}{l}\text { Body } \\
\text { part }\end{array}$} & \multirow[t]{2}{*}{ Training task } & \multirow[t]{2}{*}{ Focus } & \multirow{2}{*}{$\begin{array}{l}\text { Measurement } \\
\text { events }\end{array}$} & \multicolumn{2}{|c|}{ Results } & \multirow{2}{*}{$\begin{array}{l}\text { Study } \\
\text { rating }\end{array}$} \\
\hline & & & & & & & & & & & & & & & & & $\begin{array}{l}\text { Relative } \\
\text { change }\end{array}$ & $\begin{array}{l}\text { Absolute } \\
\text { change }\end{array}$ & \\
\hline [127] & $\begin{array}{l}\text { Coffman, } \\
\text { DD }\end{array}$ & 1990 & USA & E & 1 & 1 & $\mathrm{CCT}$ & 8 & 2 & Musicians & Both & $\begin{array}{l}\text { Mean }=23, \\
\text { range } 18 \\
\text { to } 58\end{array}$ & $\begin{array}{l}\text { Upper } \\
\text { limb }\end{array}$ & Piano-playing performance & M & $\begin{array}{l}2 \text { (pre- } \\
\text { post-test) }\end{array}$ & $x$ & $>$ & $5 / 10$ \\
\hline [128] & Ross, SL & 1985 & USA & E & 1 & 1 & $\mathrm{RCT}$ & 5 & 51 & Trombonists & Both & $\begin{array}{l}\text { Mean }=22, \\
\text { range } 18 \\
\text { to } 29\end{array}$ & $\begin{array}{l}\text { Upper } \\
\text { limb }\end{array}$ & $\begin{array}{l}\text { Trombone-playing } \\
\text { performance }\end{array}$ & M & $\begin{array}{l}2 \text { (pre- } \\
\text { post-test) }\end{array}$ & 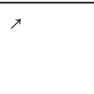 & $x$ & $7 / 10$ \\
\hline [129] & $\begin{array}{l}\text { Rubin- } \\
\text { Rabson, } \\
\text { G }\end{array}$ & 1941 & USA & E & 168 & 999 & $c \subset$ & 3 & 13 & Piano teachers & NSt & $\begin{array}{l}\text { range } 21 \\
\text { to } 25\end{array}$ & $\begin{array}{l}\text { Upper } \\
\text { limb }\end{array}$ & $\begin{array}{l}\text { Piano-playing performance, } \\
\text { memorising new études }\end{array}$ & M & $\begin{array}{l}3 \text { (during } \\
\text { int., post- } \\
\text { test) }\end{array}$ & $x$ & $x$ & $4 / 10$ \\
\hline [130] & $\begin{array}{l}\text { Sonnen- } \\
\text { schein, I }\end{array}$ & 1990 & DE & G & 3 & 3 & CS & N/A & 20 & Piano players & Both & $\begin{array}{l}\text { Mean }=33 \text {, } \\
\text { range } 14 \\
\text { to } 51\end{array}$ & $\begin{array}{l}\text { Upper } \\
\text { limb }\end{array}$ & Piano-playing performance & M & $\begin{array}{l}2 \text { (pre- } \\
\text { post-test) }\end{array}$ & N/A & 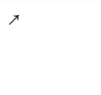 & $4 / 11$ \\
\hline [131] & Theiler, $T$ & 1995 & USA & $E$ & 1 & 1 & CCT & 4 & 14 & $\begin{array}{l}\text { Music students: guitar } \\
\text { majors, voice majors }\end{array}$ & NSt. & $\begin{array}{l}\text { Range } \\
19 \text { to } 29\end{array}$ & $\begin{array}{l}\text { Upper } \\
\text { limb }\end{array}$ & $\begin{array}{l}\text { Guitar-playing + vocal } \\
\text { performances }\end{array}$ & M & $\begin{array}{l}2 \text { (pre- } \\
\text { post-test) }\end{array}$ & 7 & $x^{\prime}$ & $5 / 10$ \\
\hline
\end{tabular}


Table 6 Overview of extracted descriptive study data for the discipline Psychology

Reference First author Year Country Language Study Intervention Study Study Number of Participants

Gender Age, years

Body part Training task

Focus Measurement

Measure
events

Study $\begin{array}{ll}\begin{array}{l}\text { duration, duration, design groups participants } \\ \text { days }\end{array} & \text { days }\end{array}$

events

Relative Absolute

change change

\begin{tabular}{|c|c|c|c|c|c|c|c|c|c|c|c|c|c|c|c|c|c|c|c|}
\hline [132] & Allami, $\mathrm{N}$ & 2008 & $F R$ & $\mathrm{E}$ & 1 & 1 & RCT & 5 & 25 & Students & NSt & $\begin{array}{l}\text { Mean }=29, \\
\text { range } 20 \text { to } 37\end{array}$ & Upper limb & Grasping task & M & $\begin{array}{l}2 \text { (pre- } \\
\text { post-test) }\end{array}$ & $x$ & $x$ & $7 / 10$ \\
\hline [133] & Alves, J & 1999 & PT & E & 28 & 28 & $\mathrm{CCT}$ & 4 & 64 & Pupils & Both & Range 15 to 17 & $\begin{array}{l}\text { Whole } \\
\text { body }\end{array}$ & Volleyball service & M & $\begin{array}{l}2 \text { (pre- } \\
\text { post-test) }\end{array}$ & $\rightarrow$ & ${ }^{x}$ & $3 / 10$ \\
\hline [134] & Andre, C & 1986 & USA & E & 5 & 5 & $\mathrm{CCT}$ & 3 & 66 & Students & Male & Mean $=21 \pm 3$ & $\begin{array}{l}\text { Whole } \\
\text { body }\end{array}$ & $\begin{array}{l}\text { Frisbee disc gold } \\
\text { putting/throwing }\end{array}$ & M & $\begin{array}{l}2 \text { (pre- } \\
\text { post-test) }\end{array}$ & $\rightarrow$ & ${ }^{x}$ & $4 / 10$ \\
\hline [135] & Chevalier, H & 1986 & $C A / F R$ & $\mathrm{E}$ & 1 & 1 & RCT & 5 & 30 & Students & Both & $\begin{array}{l}\text { Undergraduate } \\
\text { students }\end{array}$ & Upper limb & $\begin{array}{l}\text { Moving computer } \\
\text { mouse }\end{array}$ & c & $\begin{array}{l}1 \text { (post- } \\
\text { test only) }\end{array}$ & ${ }^{x}$ & ${ }^{x}$ & $6 / 10$ \\
\hline [136] & Clark, LV & 1960 & USA & $\mathrm{E}$ & 28 & 21 & cСT & 2 & 144 & Pupils & Male & High-school pupils & $\begin{array}{l}\text { Whole } \\
\text { body }\end{array}$ & $\begin{array}{l}\text { Pacific coast one-hand } \\
\text { foul shot }\end{array}$ & M & $\begin{array}{l}2 \text { (pre- } \\
\text { post-test) }\end{array}$ & $\rightarrow$ & ${ }^{x}$ & $5 / 10$ \\
\hline [137] & Clegg, BC & 2004 & USA & $\mathrm{E}$ & 1 & 1 & SCRD & N/A & 28 & $\begin{array}{l}\text { Older adults, } \\
\text { students }\end{array}$ & Both & $\begin{array}{l}\text { Old: mean }=74 \\
\text { range } 62 \text { to } 88 ; \\
\text { young: } \text { mean }=22, \\
\text { range } 18 \text { to } 26\end{array}$ & Upper limb & Movement with stylus & M & $\begin{array}{l}1 \text { (post- } \\
\text { test only) }\end{array}$ & N/A & $\rightarrow$ & $8 / 11$ \\
\hline [138] & Corbin, CB & 1967 & USA & $\mathrm{E}$ & 28 & 21 & RCT & 3 & 30 & Pupils & Male & High-school pupils & $\begin{array}{l}\text { Whole } \\
\text { body }\end{array}$ & $\begin{array}{l}\text { Wand-juggling } \\
\text { skill }\end{array}$ & M & $\begin{array}{l}2 \times \mathrm{BL}, \\
\text { post-test, } \\
\text { FU } 1 \text { day }\end{array}$ & $x$ & $x$ & $5 / 10$ \\
\hline [139] & Cornwall, MW & 1991 & USA & E & 4 & 4 & RCT & 2 & 24 & Females & Female & $\begin{array}{l}\text { Mean }=23, \\
\text { range } 21 \text { to } 25\end{array}$ & Lower limb & $\begin{array}{l}\text { Strength of quadriceps } \\
\text { muscle }\end{array}$ & s & $\begin{array}{l}2 \text { (pre- } \\
\text { post-test) }\end{array}$ & $>$ & ${ }^{r}$ & $6 / 10$ \\
\hline [140] & Decety, J & 1991 & USA & E & 1 & 1 & RCT & 2 & 20 & Students & Both & Mean $=23 \pm 2$ & Lower limb & Walking on beam & M & $\begin{array}{l}5 \text { (during int., } \\
\text { post-test) }\end{array}$ & ${ }^{x}$ & ${ }^{\pi}$ & $6 / 10$ \\
\hline [41] & Etnier, J & 1996 & USA & $\mathrm{E}$ & 1 & 1 & RCT & 9 & 153 & Students & Both & $\begin{array}{l}\text { Mean } \pm \mathrm{SD}= \\
23 \pm 4\end{array}$ & $\begin{array}{l}\text { Whole } \\
\text { body }\end{array}$ & $\begin{array}{l}\text { Basketball } \\
\text { shooting }\end{array}$ & M & $\begin{array}{l}3 \text { (pre-test, } \\
\text { during int., } \\
\text { post-test) }\end{array}$ & $x$ & $x$ & $6 / 10$ \\
\hline [141] & Gassner, K & 2007 & $\mathrm{DE}$ & G & 999 & 21 & RCT & 2 & 36 & Students & Both & Mean $=24$ & Lower limb & $\begin{array}{l}\text { Walking with knee } \\
\text { prosthesis }\end{array}$ & M & $\begin{array}{l}2 \text { (pre- } \\
\text { post-test) }\end{array}$ & x & ${ }^{x}$ & $7 / 10$ \\
\hline [142] & Gordon, S & 1994 & $\mathrm{AU}$ & E & 21 & 21 & RCT & 3 & 64 & $\begin{array}{l}\text { High-school } \\
\text { pupils }\end{array}$ & NSt & $\begin{array}{l}\text { High-school } \\
\text { pupils }\end{array}$ & $\begin{array}{l}\text { Whole } \\
\text { body }\end{array}$ & Cricket outswing & M & $\begin{array}{l}6 \text { (pre-test, } \\
\text { during int., } \\
\text { post-test) }\end{array}$ & $\rightarrow$ & ${ }^{x}$ & $6 / 10$ \\
\hline [143] & Gray, SW & 1990 & USA & $\mathrm{E}$ & 21 & 14.0 & $\mathrm{RCT}$ & 2 & 24 & Males & Male & $\begin{array}{l}\text { Mean }=22 \text {, } \\
\text { range } 18 \text { to } 26\end{array}$ & $\begin{array}{l}\text { Whole } \\
\text { body }\end{array}$ & $\begin{array}{l}\text { Forehand and } \\
\text { backhand racquetball } \\
\text { skills }\end{array}$ & M & 2 (pre-post-test) & $x$ & $x$ & $6 / 10$ \\
\hline [144] & Hellwing, W & 1976 & DE & G & 14 & 14 & $\mathrm{CCT}$ & 2 & 72 & Pupils & Male & $\begin{array}{l}\text { Mean }=12 \\
\text { range } 11 \text { to } 13\end{array}$ & $\begin{array}{l}\text { Whole } \\
\text { body }\end{array}$ & Fosbury flop & M & 1 (post-test) & $\rightarrow$ & ${ }^{x}$ & $4 / 10$ \\
\hline [145] & $\begin{array}{l}\text { Hemayattalab, } \\
\text { R }\end{array}$ & 2009 & $\mathbb{R}$ & $\mathrm{E}$ & 38 & 24 & RCT & 5 & 40 & $\begin{array}{l}\text { Mentally } \\
\text { retarded } \\
\text { children }\end{array}$ & NSt & $\begin{array}{l}\text { Mean }=14 \text {, } \\
\text { range } 12 \text { to } 15\end{array}$ & $\begin{array}{l}\text { Whole } \\
\text { body }\end{array}$ & $\begin{array}{l}\text { Basketball free } \\
\text { throw }\end{array}$ & M & $\begin{array}{l}3 \text { (pre-post-test, } \\
\text { FU) }\end{array}$ & x & ${ }^{x}$ & $6 / 10$ \\
\hline [146] & Herrero, J & 2004 & ES & E & 7 & 7 & $\mathrm{CCT}$ & 2 & 27 & Students & Female & $\begin{array}{l}\text { Mean } \pm \text { SD }= \\
20 \pm 0.1\end{array}$ & Upper limb & Bench-press & s & $\begin{array}{l}2 \text { (pre- } \\
\text { post-test) }\end{array}$ & ${ }^{x}$ & ${ }^{x}$ & $6 / 10$ \\
\hline [56] & Isaac, AR & 1992 & $\mathrm{NZ}$ & E & 126 & 126 & $C \subset T$ & 2 & 70 & Students & NSt & NSt & $\begin{array}{l}\text { Whole } \\
\text { body }\end{array}$ & Three trampoline skills & M & $\begin{array}{l}6 \text { (after 1, 6, } \\
7,12,13,18 \\
\text { weeks) }\end{array}$ & $\rightarrow$ & $\rightarrow$ & $6 / 10$ \\
\hline
\end{tabular}


Table 6 Overview of extracted descriptive study data for the discipline Psychology (Continued)

\begin{tabular}{|c|c|c|c|c|c|c|c|c|c|c|c|c|c|c|c|c|c|c|c|}
\hline [147] & Jaehme, W & 1978 & DE & G & 21 & 14 & RCT & 3 & 48 & Pupils & Male & Mean $=16$ & $\begin{array}{l}\text { Whole } \\
\text { body }\end{array}$ & Crawl swimming & M & $\begin{array}{l}2 \text { (pre- } \\
\text { post-test) }\end{array}$ & x & $x$ & $5 / 10$ \\
\hline [42] & Jarus, $\mathrm{T}$ & 2000 & IL & $\mathrm{E}$ & 1 & 1 & RCT & 2 & 89 & Children, adults & Both & $\begin{array}{l}\text { Children: mean } \pm \\
\text { SD }=10 \pm 1 \text {; } \\
\text { adults: } \\
28 \pm 5 \text {; older } \\
\text { adults: } \\
67 \pm 2\end{array}$ & Upper limb & $\begin{array}{l}\text { Two-arm } \\
\text { coordination } \\
\text { task }\end{array}$ & c & $\begin{array}{l}6 \text { (during int., } \\
\text { FU) }\end{array}$ & x & ${ }^{x}$ & $6 / 10$ \\
\hline [148] & Jones, JG & 1965 & $A U$ & $E$ & 14 & 14 & $\mathrm{RCT}$ & 2 & 71 & Students & Male & Students & $\begin{array}{l}\text { Whole } \\
\text { body }\end{array}$ & $\begin{array}{l}\text { Hock-swing } \\
\text { upstart }\end{array}$ & $M$ & $\begin{array}{l}2 \text { (during int., } \\
\text { post-test) }\end{array}$ & $x$ & $x$ & $7 / 10$ \\
\hline [149] & Kelsey, IB & 1961 & $C A$ & $\mathrm{E}$ & 22 & 2 & RCT & 3 & 36 & Students & Male & University students & $\begin{array}{l}\text { Trunk, } \\
\text { lower limb }\end{array}$ & $\begin{array}{l}\text { Endurance } \\
\text { abdominal }+ \\
\text { thigh-flexor } \\
\text { muscles }\end{array}$ & M & 2 (pre-post-test) & ${ }^{x}$ & 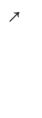 & $7 / 10$ \\
\hline [150] & Kohl, RM & 1980 & USA & $\mathrm{E}$ & 1 & 1 & $\mathrm{RCT}$ & 3 & 60 & Students & NSt & Mean $=21$ & Upper limb & $\begin{array}{l}\text { Pursuit rotor } \\
\text { task }\end{array}$ & c & $\begin{array}{l}28 \text { (during int., } \\
\text { post-test) }\end{array}$ & $\rightarrow$ & $\pi$ & $5 / 10$ \\
\hline [150] & Kohl, RM & 1980 & USA & $\mathrm{E}$ & 1 & 1 & $\mathrm{RCT}$ & 3 & 60 & Students & Male & Mean $=20$ & Upper limb & $\begin{array}{l}\text { Pursuit rotor } \\
\text { task }\end{array}$ & c & $\begin{array}{l}36 \text { (during int., } \\
\text { post-test) }\end{array}$ & $\rightarrow$ & $x$ & $5 / 10$ \\
\hline [150] & Kohl, RM & 1980 & USA & $\mathrm{E}$ & 1 & 1 & $\mathrm{RCT}$ & 6 & 108 & Pupils & Male & Mean $=17$ & Upper limb & Pursuit rotor task & c & NSt & $x$ & ${ }^{x}$ & $5 / 10$ \\
\hline [151] & Kornspan, AS & 2004 & USA & E & 5 & 4 & RCT & 4 & 40 & Students & Both & Mean $=20$ & $\begin{array}{l}\text { Whole } \\
\text { body }\end{array}$ & Golf putting & M & $\begin{array}{l}3 \text { (pre-post- } \\
\text { tes)t }\end{array}$ & $\rightarrow$ & $x$ & $6 / 10$ \\
\hline [152] & Kremer, P & 2009 & $A U$ & $\mathrm{E}$ & 1 & 1 & RCT & 4 & 209 & Students & Both & $\begin{array}{l}\text { Mean } \pm S D= \\
21 \pm 3\end{array}$ & $\begin{array}{l}\text { Whole } \\
\text { body }\end{array}$ & $\begin{array}{l}\text { Dart throwing } \\
\text { with non- } \\
\text { preferred } \\
\text { hand }\end{array}$ & M & 2 (pre-post-test) & $\rightarrow$ & ${ }^{x}$ & $7 / 10$ \\
\hline [153] & Krigolson, O & 2006 & $C A$ & $\mathrm{E}$ & 1 & 1 & $\mathrm{CCT}$ & 6 & 42 & $\begin{array}{l}\text { Healthy } \\
\text { participants }\end{array}$ & NSt & Range 18 to 32 & Lower limb & $\begin{array}{l}\text { Walking along } \\
\text { walkway }\end{array}$ & M & $\begin{array}{l}20 \text { (during int., } \\
\text { post-test) }\end{array}$ & $\rightarrow$ & ${ }^{\prime}$ & $4 / 10$ \\
\hline [57] & Lejeune, M & 1994 & $\mathrm{BE}$ & E & 7 & 4 & CCT & 4 & 40 & $\begin{array}{l}\text { University } \\
\text { students + } \\
\text { staff }\end{array}$ & Both & $\begin{array}{l}\text { Mean }=22 \text {, range } \\
19 \text { to } 27\end{array}$ & $\begin{array}{l}\text { Whole } \\
\text { body }\end{array}$ & $\begin{array}{l}\text { Counterattack } \\
\text { forehand and } \\
\text { backhand (table } \\
\text { tennis) }\end{array}$ & M & $\begin{array}{l}3 \text { (Pre-post-test, } \\
\text { FU) }\end{array}$ & x & ${ }^{\prime}$ & $5 / 10$ \\
\hline [154] & Linden, CA & 1989 & USA & E & 14 & 8 & $\mathrm{RCT}$ & 2 & 23 & $\begin{array}{l}\text { Healthy } \\
\text { participants }\end{array}$ & Female & $\begin{array}{l}\text { Mean }=79 \text {, range } \\
67 \text { to } 90\end{array}$ & $\begin{array}{l}\text { Whole } \\
\text { body }\end{array}$ & $\begin{array}{l}\text { Walking balance, } \\
\text { equilibrium } \\
\text { reactions }\end{array}$ & M & $\begin{array}{l}3 \text { (pre-test, } \\
\text { during int., } \\
\text { post-test) }\end{array}$ & $\rightarrow$ & $\rightarrow$ & $8 / 10$ \\
\hline [45] & Lutz, R & 2001 & USA & E & 1 & 1 & $\mathrm{RCT}$ & 5 & 120 & Students & Both & $\begin{array}{l}\text { Undergraduate } \\
\text { students }\end{array}$ & $\begin{array}{l}\text { Whole } \\
\text { body }\end{array}$ & Golf putting & M & $\begin{array}{l}2 \text { (pre- } \\
\text { post-test) }\end{array}$ & ${ }^{x}$ & ${ }^{x}$ & $7 / 10$ \\
\hline [155] & Maring, JR & 1990 & USA & $E$ & 1 & 1 & $\mathrm{RCT}$ & 2 & 26 & $\begin{array}{l}\text { University } \\
\text { students + } \\
\text { staff }\end{array}$ & Both & $\begin{array}{l}\text { Mean }=30 \text {; range } \\
22 \text { to } 40\end{array}$ & Upper limb & $\begin{array}{l}\text { Tossing a ping- } \\
\text { pong ball to } \\
\text { target }\end{array}$ & M & $\begin{array}{l}2 \text { (pre- } \\
\text { post-test) }\end{array}$ & $\pi$ & $x$ & $6 / 10$ \\
\hline [67] & Martin, KA & 1995 & CA & E & 6 & 6 & RCT & 3 & 39 & Students & Both & $\begin{array}{l}\text { Mean } \pm S D= \\
27 \pm 6\end{array}$ & $\begin{array}{l}\text { Whole } \\
\text { body }\end{array}$ & Golf putting & M & $\begin{array}{l}2 \text { (pre- } \\
\text { post-test) }\end{array}$ & $x$ & $x$ & $6 / 10$ \\
\hline$[156]$ & McAleney, P & 1990 & USA & $\mathrm{E}$ & 999 & 21 & RCT & 2 & 20 & Students & Both & $\begin{array}{l}\text { Mean }=19 \text {, range } \\
18 \text { to } 20\end{array}$ & $\begin{array}{l}\text { Whole } \\
\text { body }\end{array}$ & $\begin{array}{l}\text { Tennis shooting } \\
\text { skills }\end{array}$ & M & $\begin{array}{l}2 \text { (pre- } \\
\text { post-test) }\end{array}$ & $\rightarrow$ & 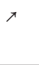 & $7 / 10$ \\
\hline$[157]$ & Minas, SC & 1978 & UK & $\mathrm{E}$ & 1 & 1 & $\mathrm{RCT}$ & 4 & 32 & Students & Both & $\begin{array}{l}\text { Undergraduate } \\
\text { students }\end{array}$ & $\begin{array}{l}\text { Whole } \\
\text { body }\end{array}$ & $\begin{array}{l}\text { Throwing } \\
\text { performance }\end{array}$ & M & $\begin{array}{l}2 \text { (pre- } \\
\text { post-test) }\end{array}$ & $\rightarrow$ & $r$ & $6 / 10$ \\
\hline [68] & 0,1 & 2008 & $C A$ & E & 999 & 1 & $\mathrm{RCT}$ & 5 & 97 & $\begin{array}{l}\text { Healthy } \\
\text { students }\end{array}$ & Both & $\begin{array}{l}\text { Mean } \pm S D= \\
18 \pm 2\end{array}$ & $\begin{array}{l}\text { Whole } \\
\text { body }\end{array}$ & $\begin{array}{l}\text { Dribbling a } \\
\text { soccer ball }\end{array}$ & M & $\begin{array}{l}2 \text { (pre- } \\
\text { post-test) }\end{array}$ & ${ }^{x}$ & ${ }^{x}$ & $7 / 10$ \\
\hline
\end{tabular}


Table 6 Overview of extracted descriptive study data for the discipline Psychology (Continued)

\begin{tabular}{|c|c|c|c|c|c|c|c|c|c|c|c|c|c|c|c|c|c|c|c|}
\hline [158] & $\begin{array}{l}\text { Papaxanthis, } \\
\text { PC }\end{array}$ & 2002 & $F R$ & $\mathrm{E}$ & 1 & 1 & RCT & 2 & 16 & Students & Both & $\begin{array}{l}\text { Mean }=21 \text {, range } \\
19 \text { to } 23\end{array}$ & $\begin{array}{l}\text { Lower + } \\
\text { upper limb }\end{array}$ & $\begin{array}{l}\text { Walking + } \\
\text { writing task }\end{array}$ & M & $\begin{array}{l}5 \text { (during int., } \\
\text { post-test) }\end{array}$ & $\rightarrow$ & $\pi$ & $6 / 10$ \\
\hline [159] & Phipps, SJ & 1969 & USA & E & 21 & 21 & $\mathrm{RCT}$ & 2 & 72 & Students & Male & University students & $\begin{array}{l}\text { Whole } \\
\text { body }\end{array}$ & $\begin{array}{l}\text { Hock swing, } \\
\text { jump-foot, } \\
\text { soccer hitch } \\
\text { kick }\end{array}$ & M & $\begin{array}{l}2 \text { (pre- } \\
\text { post-test) }\end{array}$ & ${ }^{x}$ & ' & $6 / 10$ \\
\hline [160] & $\begin{array}{l}\text { Ranganathan, } \\
\text { VK }\end{array}$ & 2004 & USA & E & 231 & 84 & $\mathrm{RCT}$ & 4 & 30 & $\begin{array}{l}\text { Healthy } \\
\text { participants }\end{array}$ & Both & $\begin{array}{l}\text { Mean } \pm S D= \\
30 \pm 5\end{array}$ & Upper limb & $\begin{array}{l}\text { Muscle strength } \\
\text { of little finger } \\
\text { abduction, elbow } \\
\text { flexion }\end{array}$ & $\mathrm{s}$ & $\begin{array}{l}18 \text { (BL, during } \\
\text { int., FU) }\end{array}$ & $\rightarrow$ & ${ }^{x}$ & $6 / 10$ \\
\hline [35] & Rapp, G & 1973 & DE & G & 14 & 9 & $\mathrm{RCT}$ & 3 & 58 & $\begin{array}{l}\text { Pre-school } \\
\text { children }\end{array}$ & Both & Mean $=6$ & $\begin{array}{l}\text { Whole } \\
\text { body }\end{array}$ & Skipping & M & 2 (pre-post-test) & $\rightarrow$ & ${ }^{x}$ & $7 / 10$ \\
\hline [161] & Rawlings, E & 1972 & USA & E & 11 & 10 & $\mathrm{RCT}$ & 3 & 24 & Students & Female & $\begin{array}{l}\text { Undergraduate } \\
\text { students }\end{array}$ & Upper limb & Rotary pursuit tracking & c & $\begin{array}{l}10 \text { (pre-test, } \\
\text { during int., } \\
\text { post-test) }\end{array}$ & $\rightarrow$ & ${ }^{x}$ & $6 / 10$ \\
\hline [161] & RawlingsE & 1972 & USA & E & 10 & 9 & $R C T$ & 2 & 20 & Students & Male & Students & Upper limb & Rotary pursuit tracking & c & $\begin{array}{l}10 \text { (pre-test, } \\
\text { during int., } \\
\text { post-test) }\end{array}$ & $\rightarrow$ & 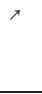 & $5 / 10$ \\
\hline [69] & Reiser, M & 2005 & DE & G & 28 & 28 & $\mathrm{RCT}$ & 3 & 34 & Students & Both & $\begin{array}{l}\text { Mean } \pm S D=24 \pm \\
2 \text {, range } 20 \text { to } 27\end{array}$ & Upper limb & Bench-press & $\mathrm{s}$ & $\begin{array}{l}4 \text { (pre-test, } \\
\text { during int., } \\
\text { post-test) }\end{array}$ & $x$ & ${ }^{\pi}$ & $6 / 10$ \\
\hline [83] & Rodrigues, EC & 2010 & BR & E & 1 & 1 & CS & N/A & 18 & Students & Both & $\begin{array}{l}\text { Mean }=26 \text {, range } \\
19 \text { to } 33\end{array}$ & Lower limb & Plantar flexion & M & 2 (pre-post-test) & ${ }^{x}$ & x & $9 / 11$ \\
\hline [162] & Ryan, E & 1981 & USA & $\mathrm{E}$ & 1 & 1 & $\mathrm{RCT}$ & 3 & 39 & Students & Male & $\begin{array}{l}\text { Undergraduate } \\
\text { students }\end{array}$ & $\begin{array}{l}\text { Upper limb } \\
+ \text { whole } \\
\text { body }\end{array}$ & $\begin{array}{l}\text { 'Dial-a-maze' pattern, } \\
\text { stabilometer } \\
\text { performance }\end{array}$ & M & 2 (pre-post-test) & $x$ & ${ }^{x}$ & $5 / 10$ \\
\hline [163] & Ryan, E & 1982 & USA & $\mathrm{E}$ & 1 & 1 & $R C T$ & 6 & 80 & Traffic officers & Male & $\begin{array}{l}\text { Mean }=36 \text {, range } \\
23 \text { to } 57\end{array}$ & $\begin{array}{l}\text { Whole } \\
\text { body }\end{array}$ & $\begin{array}{l}\text { Stabilometer } \\
\text { performance }\end{array}$ & M & $\begin{array}{l}4 \text { (pre-test, } \\
\text { during int., } \\
\text { post-test) }\end{array}$ & ${ }^{x}$ & ${ }^{\lambda}$ & $7 / 10$ \\
\hline [164] & Shackell, EM & 2007 & $C A$ & $\mathrm{E}$ & 21 & 10 & $R C T$ & 3 & 30 & Students & Male & $\begin{array}{l}\text { Mean } \pm S D= \\
20 \pm 2\end{array}$ & Lower limb & $\begin{array}{l}\text { Strength-training } \\
\text { of hip flexor } \\
\text { muscle }\end{array}$ & s & $\begin{array}{l}2 \text { (pre- } \\
\text { post-test) }\end{array}$ & $>$ & ${ }^{\lambda}$ & $7 / 10$ \\
\hline [165] & Sidaway, B & 2005 & USA & E & 28 & 28 & $R C T$ & 3 & 24 & Students & Both & $\begin{array}{l}\text { Mean }=23 \text {, range } \\
19 \text { to } 26\end{array}$ & Lower limb & $\begin{array}{l}\text { Ankle dorsiflexor } \\
\text { torque }\end{array}$ & M & $\begin{array}{l}2 \text { (pre- } \\
\text { post-test) }\end{array}$ & $\rightarrow$ & ${ }^{x}$ & $7 / 10$ \\
\hline [166] & Singer, RN & 1970 & USA & E & 35 & 28 & $\mathrm{RCT}$ & 5 & 65 & Students & Female & College students & Upper limb & $\begin{array}{l}\text { Learning a pursuit } \\
\text { rotor task }\end{array}$ & c & $\begin{array}{l}2 \text { (pre- } \\
\text { post-test) }\end{array}$ & $\rightarrow$ & ${ }^{x}$ & $5 / 10$ \\
\hline [167] & Smith, LE & 1962 & USA & E & 1 & 1 & $\mathrm{C \subset T}$ & 6 & 60 & Students & Male & $\begin{array}{l}\text { Mean }=20 \text {, range } \\
17 \text { to } 27\end{array}$ & Upper limb & $\begin{array}{l}\text { Hand-eye coordination } \\
\text { task; punchboard } \\
\text { learning task }\end{array}$ & M & $\begin{array}{l}2 \text { (pre- } \\
\text { post-test) }\end{array}$ & $\rightarrow$ & ${ }^{x}$ & $4 / 10$ \\
\hline [72] & Smith, D & 2001 & UK & E & 21 & 21 & $\mathrm{RCT}$ & 2 & 27 & Students & Both & $\begin{array}{l}\text { Mean } \pm \text { SD }= \\
20 \pm 3\end{array}$ & $\begin{array}{l}\text { Whole } \\
\text { body }\end{array}$ & $\begin{array}{l}\text { Landing hockey } \\
\text { penalty }\end{array}$ & M & $\begin{array}{l}2 \text { (pre- } \\
\text { post-test) }\end{array}$ & ${ }^{x}$ & $x$ & $7 / 10$ \\
\hline [71] & Smith, D & 2004 & UK & E & 49 & 49 & $\mathrm{RCT}$ & 3 & 19 & $\begin{array}{l}\text { University } \\
\text { students + staff }\end{array}$ & Male & $\begin{array}{l}\text { Mean } \pm \mathrm{SD}= \\
30 \pm 8\end{array}$ & Upper limb & $\begin{array}{l}\text { Strength of abductor } \\
\text { digiti minimi }\end{array}$ & s & $\begin{array}{l}2 \text { (pre- } \\
\text { post-test) }\end{array}$ & $\rightarrow$ & $x$ & $7 / 10$ \\
\hline [71] & Smith, D & 2004 & UK & $\mathrm{E}$ & 1 & 1 & $R C T$ & 4 & 24 & $\begin{array}{l}\text { University } \\
\text { students + staff }\end{array}$ & Both & $\begin{array}{l}\text { Mean } \pm \text { SD }= \\
29 \pm 8\end{array}$ & Upper limb & $\begin{array}{l}\text { Barrier knock- } \\
\text { down task }\end{array}$ & c & $\begin{array}{l}2 \text { (pre- } \\
\text { post-test) }\end{array}$ & $\rightarrow$ & ${ }^{x}$ & $7 / 10$ \\
\hline [168] & Smyth, MM & 1975 & UK & E & 1 & 1 & $R C T$ & 7 & 70 & Students & Both & $\begin{array}{l}\text { Undergraduate } \\
\text { and postgraduate } \\
\text { students }\end{array}$ & Upper limb & $\begin{array}{l}\text { Mirror drawing } \\
\text { of a star }\end{array}$ & c & $\begin{array}{l}2 \text { (pre- } \\
\text { post-test) }\end{array}$ & $x$ & ${ }^{x}$ & $5 / 10$ \\
\hline
\end{tabular}


Table 6 Overview of extracted descriptive study data for the discipline Psychology (Continued)

\begin{tabular}{|c|c|c|c|c|c|c|c|c|c|c|c|c|c|c|c|c|c|c|c|}
\hline [168] & Smyth, MM & 1975 & UK & E & 1 & 1 & RCT & 7 & 71 & Students & Both & $\begin{array}{l}\text { Undergraduate } \\
\text { and postgraduate } \\
\text { students }\end{array}$ & Upper limb & $\begin{array}{l}\text { Pursuit rotor } \\
\text { task }\end{array}$ & c & 1 (post-test) & $x$ & $x$ & $5 / 10$ \\
\hline [169] & Start, KB & 1960 & $\mathrm{AU}$ & $\mathrm{E}$ & 9 & 9 & CS & N/A & 35 & Pupils & Male & 12 & $\begin{array}{l}\text { Whole } \\
\text { body }\end{array}$ & Basketball throw & M & 2 (pre-post-test) & N/A & $x$ & $6 / 11$ \\
\hline [170] & Start, KB & 1964 & $\mathrm{AU}$ & E & 7 & 6 & CS & N/A & 21 & Students & Male & $\begin{array}{l}\text { Mean }=20 \text {, range } \\
18 \text { to } 21\end{array}$ & $\begin{array}{l}\text { Whole } \\
\text { body }\end{array}$ & $\begin{array}{l}\text { Single leg upstart on } \\
\text { high-bar }\end{array}$ & M & 1 (post-test) & N/A & $x$ & $7 / 11$ \\
\hline [87] & Start, KB & 1964 & $\mathrm{AU}$ & E & 7 & 6 & CS & N/A & 44 & Students & Male & $\begin{array}{l}\text { Mean }=19 \text {, range } \\
18 \text { to } 25\end{array}$ & $\begin{array}{l}\text { Whole } \\
\text { body }\end{array}$ & $\begin{array}{l}\text { Single leg upstart on } \\
\text { high-bar }\end{array}$ & M & 1 (post-test) & $\mathrm{N} / \mathrm{A}$ & $\rightarrow$ & $7 / 11$ \\
\hline [88] & Start, KB & 1964 & $\mathrm{AU}$ & E & 14 & 6 & CS & N/A & 32 & Students & Male & $\begin{array}{l}\text { Mean }=20 \text {, range } \\
18 \text { to } 21\end{array}$ & $\begin{array}{l}\text { Whole } \\
\text { body }\end{array}$ & $\begin{array}{l}\text { Single leg upstart on } \\
\text { high-bar }\end{array}$ & M & 1 (post-test) & $\mathrm{N} / \mathrm{A}$ & $\rightarrow$ & $6 / 11$ \\
\hline [171] & Stebbins, RJ & 1968 & USA & E & 42 & 21 & $\mathrm{RCT}$ & 5 & 93 & Students & Male & College students & $\begin{array}{l}\text { Whole } \\
\text { body }\end{array}$ & $\begin{array}{l}\text { Throwing ball into } \\
\text { target }\end{array}$ & M & $\begin{array}{l}\text { 8-18 (pre-test, } \\
\text { during int., } \\
\text { post-test) }\end{array}$ & $\rightarrow$ & ${ }^{x}$ & $5 / 10$ \\
\hline [172] & Surburg, PR & 1968 & USA & E & 63 & 56 & CCT & 7 & 183 & Students & Male & $\begin{array}{l}\text { Junior college } \\
\text { students }\end{array}$ & $\begin{array}{l}\text { Whole } \\
\text { body }\end{array}$ & Tennis forehand drive & M & 2 (pre-post-test) & $\rightarrow$ & $x$ & $5 / 10$ \\
\hline [36] & Taktek, K & 2004 & $C A$ & $\mathrm{E}$ & 1 & 1 & CCT & 4 & 64 & Children & Both & $\begin{array}{l}\text { Mean }=9 \text {, range } \\
8 \text { to } 10\end{array}$ & Upper limb & Pushing play vehicle & c & 2 (pre-post-test) & $\rightarrow$ & $x$ & $4 / 10$ \\
\hline [73] & Toussaint, L & 2010 & $F R$ & E & 3 & 2 & $\mathrm{RCT}$ & 8 & 80 & Students & Both & $\begin{array}{l}\text { Mean } \pm S D= \\
23 \pm 3\end{array}$ & Lower limb & Knee joint angles & M & $\begin{array}{l}3 \text { (pre-post-test, } \\
\text { FU) }\end{array}$ & $\rightarrow$ & ${ }^{x}$ & $6 / 10$ \\
\hline [173] & Tunney, N & 2006 & USA & $\mathrm{E}$ & 2 & 2 & $\mathrm{RCT}$ & 2 & 19 & Older adults & Both & $\begin{array}{l}\text { Mean }=76 \text {, range } \\
66 \text { to } 89\end{array}$ & Lower limb & $\begin{array}{l}\text { Walking with quad } \\
\text { cane + climbing four } \\
\text { stairs }\end{array}$ & M & 2 (pre-post-test) & $\rightarrow$ & ${ }^{x}$ & $7 / 10$ \\
\hline [174] & Twining, W & 1949 & USA & E & 22 & 20 & RCT & 3 & 36 & Students & Male & College students & $\begin{array}{l}\text { Whole } \\
\text { body }\end{array}$ & $\begin{array}{l}\text { Throwing rings at } \\
\text { target }\end{array}$ & M & 2 (pre-post-test) & -1 & $x$ & $4 / 10$ \\
\hline [175] & van Gyn, GH & 1990 & CA & $\mathrm{E}$ & 42 & 42 & RCT & 4 & 40 & Students & Both & $\begin{array}{l}\text { Undergraduate } \\
\text { students }\end{array}$ & Lower limb & $\begin{array}{l}\text { Power }+ \text { sprint } \\
\text { performance on } \\
\text { ergometer }\end{array}$ & M & 2 (pre-post-test) & $\rightarrow$ & $x$ & $6 / 10$ \\
\hline [176] & Vandell, RA & 1943 & USA & E & 20 & 18 & $\mathrm{RCT}$ & 3 & 36 & $\begin{array}{l}\text { Pupils and } \\
\text { college students }\end{array}$ & Male & $\begin{array}{l}\text { Junior, senior } \\
\text { high- } \\
\text { school and college } \\
\text { students }\end{array}$ & $\begin{array}{l}\text { Whole } \\
\text { body }\end{array}$ & $\begin{array}{l}\text { Throwing darts at } \\
\text { target, basketball free } \\
\text { throws }\end{array}$ & M & 2 (pre-post-test) & $\rightarrow$ & $x$ & $5 / 10$ \\
\hline [37] & Vergeer, I & 2006 & UK & E & 28 & 28 & $\mathrm{RCT}$ & 3 & 36 & University staff & Both & $\begin{array}{l}\text { Mean } \pm S D= \\
41 \pm 10\end{array}$ & Lower limb & $\begin{array}{l}\text { Flexibility around hip } \\
\text { joint }\end{array}$ & M & 2 (pre-post-test) & $\rightarrow$ & ${ }^{x}$ & $7 / 10$ \\
\hline [74] & Wakefield, CJ & 2009 & UK & E & 999 & 28 & RCT & 4 & 32 & Students & Female & University students & $\begin{array}{l}\text { Whole } \\
\text { body }\end{array}$ & $\begin{array}{l}\text { Netball shooting } \\
\text { performance }\end{array}$ & c & 2 (pre-post-test) & $\pi$ & ${ }^{x}$ & $7 / 10$ \\
\hline [75] & White, KD & 1979 & $\mathrm{AU}$ & E & 9 & 8 & $\mathrm{CCT}$ & 4 & 24 & $\begin{array}{l}\text { High-school } \\
\text { pupils }+ \\
\text { university } \\
\text { students }\end{array}$ & NSt & $\begin{array}{l}\text { Mean }=19 \text {, range } \\
13 \text { to } 27\end{array}$ & $\begin{array}{l}\text { Whole } \\
\text { body }\end{array}$ & $\begin{array}{l}\text { Action-reaction } \\
\text { swimming start }\end{array}$ & M & 2 (pre-post-test) & $\rightarrow$ & ${ }^{x}$ & $4 / 10$ \\
\hline [177] & Whiteley, G & 1966 & UK & $\mathrm{E}$ & 84 & 84 & $\mathrm{c \subset T}$ & 4 & 88 & Pupils & Male & Mean $=11$ & $\begin{array}{l}\text { Whole } \\
\text { body }\end{array}$ & $\begin{array}{l}\text { Neck spring, head } \\
\text { spring, short-arm } \\
\text { overswing }\end{array}$ & M & 1 (post-test) & ${ }^{x}$ & ${ }^{x}$ & $3 / 10$ \\
\hline [76] & Williams, JG & 2004 & UK & E & 21 & 21 & $\mathrm{RCT}$ & 3 & 24 & $\begin{array}{l}\text { Undergraduate } \\
\text { students }\end{array}$ & Both & $\begin{array}{l}\text { Mean } \pm S D= \\
21 \pm 2\end{array}$ & Lower limb & Rom hip flexion & M & $\begin{array}{l}6 \text { (pre-test, } \\
\text { during int., } \\
\text { post-test, FU) }\end{array}$ & ${ }^{x}$ & ${ }^{x}$ & $7 / 10$ \\
\hline
\end{tabular}


Table 6 Overview of extracted descriptive study data for the discipline Psychology (Continued)

\begin{tabular}{|c|c|c|c|c|c|c|c|c|c|c|c|c|c|c|c|c|c|c|c|}
\hline [178] & $\begin{array}{l}\text { Wohldamm, } \\
\text { EL }\end{array}$ & 2007 & USA & $\mathrm{E}$ & 84 & 2 & CCT & 4 & 80 & Students & NSt & $\begin{array}{l}\text { Undergraduate } \\
\text { and postgraduate } \\
\text { students }\end{array}$ & Upper limb & Number typing task & M & 2 (post-test) & $\rightarrow$ & $x$ & $4 / 10$ \\
\hline [178] & $\begin{array}{l}\text { Wohldamm, } \\
\text { EL }\end{array}$ & 2007 & USA & E & 1 & 1 & CCT & 4 & 108 & Students & NSt & $\begin{array}{l}\text { Undergraduate } \\
\text { and postgraduate } \\
\text { students }\end{array}$ & Upper limb & Number typing task & M & 3 (pre-test, FU) & $\rightarrow$ & ${ }^{x}$ & $5 / 10$ \\
\hline [179] & Woolfolk, RL & 1985 & USA & $\mathrm{E}$ & 1 & 1 & $\mathrm{RCT}$ & 6 & 48 & Students & Male & $\begin{array}{l}\text { Undergraduate } \\
\text { college students }\end{array}$ & $\begin{array}{l}\text { Whole } \\
\text { body }\end{array}$ & $\begin{array}{l}\text { Putt golf balls } \\
\text { into cup }\end{array}$ & M & 2 (pre-post-test) & $\rightarrow$ & ${ }^{x}$ & $7 / 10$ \\
\hline [180] & Woolfolk, RL & 1985 & USA & E & 7 & 6 & $\mathrm{RCT}$ & 3 & 30 & Students & Both & College students & $\begin{array}{l}\text { Whole } \\
\text { body }\end{array}$ & $\begin{array}{l}\text { Golf backswing and } \\
\text { putting stroke }\end{array}$ & M & 2 (pre-post test) & ${ }^{\nearrow}$ & r & $5 / 10$ \\
\hline [77] & Wright, $C J$ & 2009 & UK & E & 999 & 42 & $\mathrm{RCT}$ & 5 & 50 & Students & NSt & $\begin{array}{l}\text { Mean } \pm S D= \\
21 \pm 4\end{array}$ & Upper limb & Biceps curl task & $\mathrm{s}$ & 2 (pre-post-test) & ${ }^{x}$ & ${ }^{x}$ & $7 / 10$ \\
\hline [78] & Yaguez, L & 1998 & DE & E & 1 & 1 & ССT & 2 & 58 & Volunteers & Both & $\begin{array}{l}\text { Mean } \pm S D= \\
35 \pm 11 \text {, range } \\
22 \text { to } 73\end{array}$ & Upper limb & Ideogram drawing & c & $\begin{array}{l}3 \text { (pre-test, } \\
\text { during int., } \\
\text { post-test) }\end{array}$ & $\rightarrow$ & $r$ & $6 / 10$ \\
\hline [78] & Yaguez, L & 1998 & DE & G & 1 & 1 & CCT & 2 & 52 & Volunteers & Both & $\begin{array}{l}\text { Mean }=30 \text {, range } \\
22 \text { to } 49\end{array}$ & Upper limb & Connecting circles & c & $\begin{array}{l}3 \text { (pre-test, } \\
\text { during int, } \\
\text { post-test) }\end{array}$ & ${ }^{x}$ & ${ }^{x}$ & $6 / 10$ \\
\hline [181] & Zecker, SG & 1982 & USA & E & 1 & 1 & $\mathrm{RCT}$ & 4 & 40 & Students & Both & $\begin{array}{l}\text { Undergraduate } \\
\text { college students }\end{array}$ & $\begin{array}{l}\text { Whole } \\
\text { body }\end{array}$ & $\begin{array}{l}\text { Tossing beanbag } \\
\text { to target }\end{array}$ & M & 2 (pre-post-test) & ${ }^{x}$ & ${ }^{x}$ & $5 / 10$ \\
\hline
\end{tabular}




\section{Table 7 Overview of extracted descriptive study data for the discipline Sports}

\begin{tabular}{|c|c|c|c|c|c|c|c|c|c|c|c|c|c|c|c|c|c|c|c|}
\hline \multirow[t]{2}{*}{ Reference } & \multirow{2}{*}{$\begin{array}{l}\text { First } \\
\text { author }\end{array}$} & \multirow[t]{2}{*}{ Year } & \multirow[t]{2}{*}{ Country } & \multirow[t]{2}{*}{ Language } & \multirow{2}{*}{$\begin{array}{l}\text { Study } \\
\text { duration, } \\
\text { days }\end{array}$} & \multirow{2}{*}{$\begin{array}{l}\text { Intervention } \\
\text { duration, } \\
\text { days }\end{array}$} & \multirow{2}{*}{$\begin{array}{l}\text { Study } \\
\text { design }\end{array}$} & \multirow{2}{*}{$\begin{array}{l}\text { Study } \\
\text { groups }\end{array}$} & \multirow{2}{*}{$\begin{array}{l}\text { Number of } \\
\text { participants }\end{array}$} & \multirow[t]{2}{*}{ Participants } & \multirow[t]{2}{*}{ Gender } & \multirow[t]{2}{*}{ Age, years } & \multirow{2}{*}{$\begin{array}{l}\text { Body } \\
\text { part }\end{array}$} & \multirow[t]{2}{*}{ Training task } & \multirow[t]{2}{*}{ Focus } & \multirow{2}{*}{$\begin{array}{l}\text { Measurement } \\
\text { events }\end{array}$} & \multicolumn{2}{|c|}{ Results } & \multirow{2}{*}{$\begin{array}{l}\text { Study } \\
\text { rating }\end{array}$} \\
\hline & & & & & & & & & & & & & & & & & $\begin{array}{l}\text { Relative } \\
\text { change }\end{array}$ & $\begin{array}{l}\text { Absolute } \\
\text { change }\end{array}$ & \\
\hline [182] & Casby, A & 1998 & UK & $\mathrm{E}$ & 84 & 46 & SCRD & N/A & 4 & $\begin{array}{l}\text { Expert } \\
\text { swimmers }\end{array}$ & Both & $\begin{array}{l}\text { Mean }=16 \text {, } \\
\text { range } 16 \text { to } 17\end{array}$ & $\begin{array}{l}\text { Whole } \\
\text { body }\end{array}$ & $\begin{array}{l}\text { Freestyle } \\
\text { swimming turn }\end{array}$ & M & $\begin{array}{l}50 \text { (pre-test, } \\
\text { during int., } \\
\text { post-test) }\end{array}$ & N/A & $\rightarrow$ & $8 / 11$ \\
\hline [54] & Grouios, G & 1992 & GR & $\mathrm{E}$ & 14 & 7 & RCT & 5 & 100 & $\begin{array}{l}\text { Top level } \\
\text { athletes }\end{array}$ & Male & $\begin{array}{l}\text { Mean }=22 \\
\text { range } 18 \text { to } 25\end{array}$ & $\begin{array}{l}\text { Upper } \\
\text { limb }\end{array}$ & Pushing button & c & $\begin{array}{l}2 \text { (pre-post } \\
\text { test) }\end{array}$ & $x$ & $x^{x}$ & $7 / 10$ \\
\hline [183] & Guillot, A & 2009 & $F R$ & $\mathrm{E}$ & 56 & 42 & CS & N/A & 10 & $\begin{array}{l}\text { Basketball } \\
\text { players }\end{array}$ & Female & Mean $=23$ & $\begin{array}{l}\text { Whole } \\
\text { body }\end{array}$ & $\begin{array}{l}\text { Three strategic } \\
\text { basketball tactics }\end{array}$ & c & $\begin{array}{l}2 \text { (pre-post } \\
\text { test) }\end{array}$ & N/A & ${ }^{x}$ & $8 / 11$ \\
\hline [55] & Guillot, A & 2010 & $F R$ & $\mathrm{E}$ & 999 & 35 & RCT & 2 & 21 & $\begin{array}{l}\text { Synchronised } \\
\text { swimmers }\end{array}$ & Female & $\begin{array}{l}\text { Mean }=15, \\
\text { SD } 2\end{array}$ & $\begin{array}{l}\text { Whole } \\
\text { body }\end{array}$ & Stretching exercises & M & $\begin{array}{l}2 \text { (pre-post } \\
\text { test) }\end{array}$ & $x$ & $x$ & $7 / 10$ \\
\hline [184] & Olsson, CJ & 2008 & SE & E & 999 & 42 & RCT & 2 & 19 & $\begin{array}{l}\text { High-jump } \\
\text { athletes }\end{array}$ & Both & $\begin{array}{l}\text { Mean }=19 \pm 3, \\
\text { range } 16 \text { to } 29\end{array}$ & $\begin{array}{l}\text { Whole } \\
\text { body }\end{array}$ & High jump & M & $\begin{array}{l}2 \text { (pre-post } \\
\text { test) }\end{array}$ & ${ }^{x}$ & ${ }^{x}$ & $6 / 10$ \\
\hline [79] & Robin, $\mathrm{N}$ & 2007 & $F R$ & E & 70 & 56 & $\mathrm{CCT}$ & 3 & 30 & Tennis players & NSt & Mean $=19 \pm 3$ & $\begin{array}{l}\text { Whole } \\
\text { body }\end{array}$ & $\begin{array}{l}\text { Tennis service } \\
\text { return }\end{array}$ & M & $\begin{array}{l}2 \text { (pre-post } \\
\text { test) }\end{array}$ & $\rightarrow$ & ${ }^{x}$ & $6 / 10$ \\
\hline [185] & $\begin{array}{l}\text { Shambrook, } \\
\text { CJ }\end{array}$ & 1996 & UK & $\mathrm{E}$ & 84 & 84 & SCRD & N/A & 4 & $\begin{array}{l}\text { Basketball } \\
\text { players }\end{array}$ & Female & $\begin{array}{l}\text { Mean }=20, \\
\text { SD } 2\end{array}$ & $\begin{array}{l}\text { Whole } \\
\text { body }\end{array}$ & $\begin{array}{l}\text { Basketball free } \\
\text { throw }\end{array}$ & M & $\begin{array}{l}26 \text { (pre-test, } \\
\text { during int., } \\
\text { post-test) }\end{array}$ & N/A & ${ }^{x}$ & $9 / 11$ \\
\hline [80] & Smith, D & 2007 & UK & E & 999 & 42 & RCT & 4 & 48 & $\begin{array}{l}\text { University } \\
\text { hockey } \\
\text { players }\end{array}$ & Both & Mean $=20 \pm 3$ & $\begin{array}{l}\text { Whole } \\
\text { body }\end{array}$ & $\begin{array}{l}\text { Field hockey } \\
\text { penalty flicks }\end{array}$ & c & $\begin{array}{l}2 \text { (pre-post } \\
\text { test) }\end{array}$ & ${ }^{x}$ & ${ }^{x}$ & $7 / 10$ \\
\hline [80] & Smith, D & 2007 & UK & $\mathrm{E}$ & 999 & 42 & RCT & 4 & 40 & $\begin{array}{l}\text { Junior } \\
\text { gymnasts }\end{array}$ & Female & $\begin{array}{l}\text { Mean }=10 \pm 2 \text { r } \\
\text { range } 7 \text { to } 14\end{array}$ & $\begin{array}{l}\text { Whole } \\
\text { body }\end{array}$ & $\begin{array}{l}\text { Full turning } \\
\text { straight jump }\end{array}$ & c & $\begin{array}{l}2 \text { (pre-post } \\
\text { test) }\end{array}$ & $\rightarrow$ & ${ }^{x}$ & $8 / 10$ \\
\hline [81] & Smith, D & 2008 & UK & $\mathrm{E}$ & 999 & 42 & RCT & 4 & 32 & Golf players & Male & NSt & $\begin{array}{l}\text { Whole } \\
\text { body }\end{array}$ & $\begin{array}{l}\text { Hitting golf ball } \\
\text { out of bunker }\end{array}$ & M & $\begin{array}{l}2 \text { (pre-post } \\
\text { test) }\end{array}$ & $x$ & ${ }^{x}$ & $7 / 10$ \\
\hline [186] & Ziemainz, H & 2003 & DE & G & 14 & 2 & RCT & 3 & 27 & Triathletes & Both & $\begin{array}{l}\text { Mean }=16 \\
\text { range } 15 \text { to } 17\end{array}$ & $\begin{array}{l}\text { Whole } \\
\text { body }\end{array}$ & $\begin{array}{l}\text { Changing between } \\
\text { triathlon-specific } \\
\text { sports }\end{array}$ & M & $\begin{array}{l}3 \text { (pre-post } \\
\text { test, FU) }\end{array}$ & $\rightarrow$ & 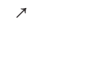 & $5 / 10$ \\
\hline
\end{tabular}


results are rarely published. This hypothesis is further supported by our identification during the selection process of abstracts detailing preliminary results of MI interventions but no follow-up full article describing the whole MI intervention and its final results. Nevertheless, the aim of this review was to analyse MI interventions with positive results, and to identify discipline-specific $\mathrm{MI}$ interventions and fundamental intervention designs.

We found that the reporting standard of MI intervention had improved in recent years; however, investigations published before 2007 often lacked details on MITS elements, which resulted in missing data in the frequency analyses. Many investigations included more than one experimental or control group. In such cases, we focused our analyses focused on the experimental group with the largest change in measurement between pre- and post-intervention measurement.

The MI interventions were heterogeneous, which explained the large standard deviations in temporal parameters.

Task evaluation is complex and subjective, and to date, no standard classification exists. In our review we classified the investigated tasks based on their main focus: motor, cognitive or strength.

Before applying an MI intervention, it is essential to evaluate the MI ability of the participants to determine whether they are able to perform MI. Additionally, MI ability might change over an intervention period. In the current literature review, we found that assessments of MI ability had been used in thirty-six studies with positive results [36-38,54-83] and in five studies with no change or with negative results [84-88]. Heterogeneity between the MI ability assessments used, which were partially custom-designed for individual MI interventions, prevented direct comparison and relation to the study results in this review. We hope this will encourage researchers to use assessments of MI ability and to state participant scores in their research reports.

This review does not include MI interventions that were published after June 2010, because of the reference selection and analysis process. However, we briefly mention new articles currently under review in Medicine. Braun et al. embedded MI training into regular therapy in patients with stroke in nursing homes and in patients with Parkinson disease at different disease levels. In both investigations, embedded MI did not show a significant advantage compared with the control group receiving regular care $[89,90]$. These interventions may add information for analysing positive results versus no change or negative results.

The current review focused on MITS elements to improve motor function or learn a motor skill. Further reviews should consider the influence of $\mathrm{MI}$ on psychological factors, such as goal-setting [91], selfefficacy, motivation and mood [92], and working memory.

\section{Conclusion}

This review covering five disciplines identified key MITS elements and temporal parameters of a successful MI intervention design. Successful design characteristics were dominant in the Psychology literature for all of the following: interventions using motor and strengthfocused tasks, interventions with participants aged 20 to 29 years old, and interventions including both genders. Four MI elements were identified that differed between experiments with positive results and those with no change or negative results; however, success was not related to intervention study design. MI interventions in Education, Medicine, Music and Sports were adapted for different MITS elements and temporal parameters. No distinct characteristics were identified regarding the choice of group or individual sessions. Reports on MI interventions did not use consistent terminology, and often lacked details on MITS elements and temporal parameters. We hope this review will prompt researchers to a coherent usage of the MI term, which could facilitate subsequent meta-analyses.

\section{Conflicts of interest}

The authors declare that they have no competing interests.

\section{Appendix}

Example search strategy

Search strategy Scopus database from 22 February 2007: (((TITLE-ABS-KEY("mental imagery")) OR (TITLEABS-KEY-AUTH("mental practice")) OR (TITLE-ABSKEY-AUTH("mental rehearsal")) OR (TITLE-ABS-KEYAUTH("mental movements")) OR (TITLE-ABS-KEYAUTH("eidetic imagery")) OR (TITLE-ABS-KEY-AUTH ("visual imagery")) OR (TITLE-ABS-KEY-AUTH("guided imagery")) OR (TITLE-ABS-KEY-AUTH("motor imagery")) OR (TITLE-ABS-KEY-AUTH("mental training"))) AND NOT (TITLE-ABS-KEY-AUTH("mental health"))) AND NOT (TITLE-ABS-KEY-AUTH("body image")) 2,556 references

\section{List of abbreviations}

CCT: clinical controlled trial; $C S$ : case series; $\mathrm{fMRI}$ = functional magnetic resonance imaging; MI: motor imagery; MITS: Motor Imagery Training Session; MP: mental practice; PP: physical practice; PETTLEP: physical, environment, timing, task, learning, emotion, perspective; PEDro: Physiotherapy Evidence Database; RCT = randomised controlled trial; SCRD: single-case research design

\section{Acknowledgements}

We are grateful to Mr Jo Akers, Librarian, who helped with the search strategy and the reference export from the databases. We are also very 
thankful to all librarians who helped with the identification of authors, references and publications, and provided necessary documents. Additionally, we thank all the authors who answered our requests and provided the searched literature.

\section{Funding}

The project was partially funded by the Gottfried und Julia Bangerter-Rhyner Foundation.

\section{Author details}

'Reha Rheinfelden, Rheinfelden, Switzerland. ${ }^{2}$ School of Health and Social Care, Oxford Brookes University, Oxford, UK. ${ }^{3}$ Department of Health \& Social Work, HES-SO, University of Applied Sciences, Western Switzerland, Sion, Switzerland. ${ }^{4}$ Faculty of Electrical Engineering, Technical University Eindhoven, Eindhoven, The Netherlands. ${ }^{5}$ Department of Information Technology and Electrical Engineering, ETH Zurich, Zurich, Switzerland. ${ }^{6}$ Brunel Institute for Bioengineering, Brunel University, London, UK. ${ }^{7}$ Nuffield Department of Surgical Sciences, Oxford University, Oxford, UK. ${ }^{8}$ Oxford Centre for Enablement, Oxford, UK. ${ }^{9}$ Department of Behavioural Neurology, Medical Faculty, University of Basel, Basel, Switzerland.

\section{Authors' contributions}

CS, BA, JB, UK and TE made substantial contributions to conception and design of the review. $\mathrm{CS}, \mathrm{RH}, \mathrm{OAM}, \mathrm{AS}$ made substantial contributions to acquisition of data, and analysis and interpretation of data. CS, OAM, BA, JB UK, TE were involved in drafting the manuscript and critically revising it. All authors have given final approval of the manuscript.

Received: 9 February 2011 Accepted: 17 June 2011

Published: 17 June 2011

\section{References}

1. Feltz DL, Landers DM: The effects of mental practice on motor skill learning and performance: a meta-analysis. J Sport Exerc Psych 1983, 5:25-57.

2. Feltz $D$, Landers $D M$, Becker $B J$ : A revised meta-analysis of the mental practice literature on motor skill learning. In Enhancing Human Performance: Issues, theories, and techniques. Edited by: Druckmann D, Swets JA. Washington D.C. National Academy Press; 1988:61-101.

3. Fell NT: Mental rehearsal as a complementary treatment in geriatric rehabilitation. Phys Occup Ther Geriatr 2001, 18(4):51-63.

4. Batson G: Motor imagery for stroke rehabilitation: current research as a guide to clinical practice. Alternative \& Complementary Therapies 2004, 10(2):84-89.

5. Braun SM, Beurskens AJ, Borm PJ, Schack T, Wade DT: The effects of mental practice in stroke rehabilitation: a systematic review. Arch Phys Med Rehabil 2006, 87(6):842-852.

6. Feltz DL, Landers DM, Becker BJ: A Revised Meta-analysis of the Mental Practice Literature on Motor Skill Learning. Washington, DC: National Academy Press; 1988.

7. Hall JC: Imagery practice and the development of surgical skills. Am J Surg 2002, 184(5):465.

8. Mulder T: Motor imagery and action observation: cognitive tools for rehabilitation. J Neural Transm 2007, 114(10):1265-1278.

9. Sharma N, Pomeroy VM, Baron JC: Motor imagery - A backdoor to the motor system after stroke? Stroke 2006, 37(7):1941-1952.

10. Warner L, McNeill ME: Mental imagery and its potential for physical therapy. Phys Ther 1988, 68(4):516-521.

11. Zimmermann-Schlatter A, Schuster C, Puhan M, Siekierka E, Steurer J: Efficacy of motor imagery in post-stroke rehabilitation: a systematic review. J NeuroEng Rehabil 2008, 5(8).

12. Annett J: Motor imagery: perception or action? Neuropsychologia 1995 33(11):1395-1417.

13. Driskell JC, Copper C, Moran A: Does mental practice enhance performance? J Appl Psychol 1994, 79:481-192.

14. Hamel O: "Imagerie mentale": A review of mental imagery in the French language on the world wide web. J Ment Imagery 2001, 25(1/2):83-98.

15. Honeycutt JM, Ford SG: Mental imagery and intrapersonal communication: a review of research on imagined interactions (IIs) and current developments. Communication Yearbook 2001, 25:315-346.
16. McKenna KT, Tooth LR: Mental practice and its implications for occupational therapists: A literature review. Brit J Occup Ther 1991 54(5):169-172.

17. Sheikh AA, Panagiotou NC: Use of mental imagery in psychotherapy: a critical review. Percept Mot Skills 1975, 41(2):555-585.

18. Surburg PR: Application of imagery techniques to special populations. Adap Phys Activty Quart 1989, 6(4):328-337.

19. LeBoutillier N, David FM: Mental imagery and creativity: a meta-analytic review study. Brit J Psychol 2003, 94(1):29.

20. Martin K, Moritz S, Hall C: Imagery use in sports: a literature review and applied model. Mental practice. Int J Sport Psychol 1999, 245-268.

21. Murphy SJ: Models of imagery in sport psychology: a review. J Ment Imagery 1990, , 14: 153-172.

22. Richardson A: Mental practice: a review and discussion part I. Res Q 1967, 38:95-107

23. Richardson A: Mental practice: a review and discussion II. Res Q 1967 38(2):263-273

24. Taktek K: The effects of mental imagery on the acquisition of motor skills and performance: A literature review with theoretical implications. J Ment Imagery 2004, 28:79-114.

25. Grouios G: Mental practice: a review. J Sport Behav 1992, 15(1):42-59.

26. Guillot A, Collet C: Construction of the motor imagery integrative model in sport: a review and theoretical investigation of motor imagery use. Int Rev Sport Exercise Psych 2008, 1(1):31-44

27. Van Leeuwen R, Inglis JTi: Mental practice and imagery: a potential role in stroke rehabilitation. Phys Ther Rev 1998, 3(1):47-54

28. Munroe KJ, Giacobbi PR, Hall C, Weinberg R: The four Ws of imagery use: where, when, why, and what. Sport Psychol 2000, 14(2):119-137.

29. Maclntyre T, Moran A: A qualitative investigation of meta-imagery processes and imagery direction among elite athletes. J Imagery Res Sport Phys Activity 2007, 2(1), article 4

30. Holmes PS, Collins DJ: The PETTLEP approach to motor imagery: A functional equivalence model for sport psychologists. J App/ Sport Psychol 2001, 13(1):60-83.

31. Watt AP, Morris T, Andersen MB: Issues in the development of a measure of imagery ability in sport. J Ment Imagery 2004, 28:149-180.

32. Maher CG, Sherrington C, Herbert RD, Moseley AM, Elkins M: Reliability of the PEDro scale for rating quality of randomized controlled trials. Phys Ther 2003, 83(8):713-721.

33. Tate RL, McDonald S, Perdices M, Togher L, Schultz R, Savage S: Rating the methodological quality of single-subject designs and n-of- 1 trials: introducing the Single-Case Experimental Design (SCED) Scale. Neuropsychol Rehabil 2008, 18(4):385-401.

34. Munro BH: Statistical methods for health care research. Philadelphia, Penn.: London: Lippincott Williams \& Wilkins; 52005

35. Rapp G, Schoder G: Kinesthetic imagination and learning of motor skills. Psychol Erz Unterr 1973, 20(5):279-288

36. Taktek K, Salmoni A, Rigal R: The Effects of Mental Imagery on the Learning and Transfer of a Discrete Motor Task by Young Children. $J$ Ment Imagery 2004, 28(3-4):87-120.

37. Vergeer I, J R: Movement and stretching imagery during flexibility training. Journal of sports sciences 2006, 24(2):197-208.

38. Guillot A, Lebon F, Vernay M, Girbon JP, Doyon J, Collet C: Effect of motor imagery in the rehabilitation of burn patients. J Burn Care Res 2009, 30(4):686-693

39. Cohn J: Experimentelle Untersuchungen über das Zusammenwirken des akustisch motorischen und des visuellen Gedächtnisses. Z Psychol Sinn 1897, 15:161-183.

40. Galton F: Statistics of mental imagery. Mind 1880, 5:301-318.

41. Etnier $\mathrm{J}$, Landers DM: The influence of procedural variables on the efficacy of mental practice. Sport Psychol 1996, 10(1):48-57.

42. Jarus T, Ratzon NZ: Can you imagine? The effect of mental practice on the acquisition and retention of a motor skill as a function of age. Occup ther J Res 2000, 20(3):163-178.

43. Butler T, Imperato-McGinley J, Pan H, Voyer D, Cordero J, Zhu YS, Stern E, Silbersweig D: Sex differences in mental rotation: Top-down versus bottom-up processing. Neuroimage 2006, 32(1):445-456.

44. Giacobbi P: Age and activity-level differences in the use of exercise imagery. J App/ Sport Psychol 2007, 19(4):487-493. 
45. Lutz R, Landers DM, Linder DE: Procedural variables and skill level influences on pre-performance mental practice efficacy. J Ment Imagery 2001, 25(3-4):115-134.

46. Callow N, Hardy L: The relationship between the use of kinaesthetic imagery and different visual imagery perspectives. J Sports Sci 2004 22(2):167-177

47. Moseley GL: Graded motor imagery for pathologic pain - A randomized controlled trial. Neurology 2006, 67(12):2129-2134.

48. Lorey B, Bischoff M, Pilgramm S, Stark R, Munzert J, Zentgraf K: The embodied nature of motor imagery: the influence of posture and perspective. Exp Brain Res 2009, 194(2):233-243.

49. Mahoney MJ, Avener M: Psychology of the elite athlete: an exploratory study. Cognitive Ther Res 1977, 2:135-141.

50. Ungerleider S, Golding JM: Mental practice among Olympic athletes. Percep motor skills 1991, 72:1007-1017.

51. Kim BH, Giacobbi PR Jr: The Use of exercise-related mental imagery by middle-aged adults. J Imagery Res Sport Phys Activity 2009, 4(1), Article 1.

52. Mulder $\mathrm{T}$, Hochstenbach JBH, van Heuvelen MJG, den Otter AR: Motor imagery: The relation between age and imagery capacity. Hum Movement Sci 2007, 26(2):203-211.

53. Jackson PL, Lafleur MF, Malouin F, Richards C, Doyon J: Potential role of mental practice using motor imagery in neurologic rehabilitation. Arch Phys Med Rehabil 2001, 82(8):1133-1141.

54. Grouios G: On the reduction of reaction time with mental practice. J Sport Behav 1992, 15(2):141-157.

55. Guillot A, Tolleron C, Collet C: Does motor imagery enhance stretching and flexibility? J Sport Sci 2010, 28(3):291-298

56. Isaac AR: Mental practice: Does it work in the field? Sport Psychol 1992 6(2):192-198

57. Lejeune M, Decker C, Sanchez X: Mental rehearsal in table tennis performance. Percept Motor Skills 1994, 79(Spec Issue Aug):627-641.

58. Bovend'Eerdt TJ, Dawes H, Sackley C, Izadi H, Wade DT: An integrated motor imagery program to improve functional task performance in neurorehabilitation: a single-blind randomized controlled trial. Arch Phys Med Rehabil 2010, 91(6):939-946.

59. Dickstein R, Dunsky A, Marcovitz E: Motor imagery for gait rehabilitation in post-stroke hemiparesis. Phys Ther 2004, 84(12):1167-1177.

60. Wright C, Hogard E, Ellis R, Smith D, Kelly C: Effect of PETTLEP imagery training on performance of nursing skills: Pilot study. J Adv Nurs 2008, 63(3):259-265

61. Jackson PL, Richards CL, Doyon J, Malouin Fi: The efficacy of combined physical and mental practice in the learning of a foot-sequence task after stroke: A case report. Neurorehabil Neural Repair 2004, 18(2):106-111

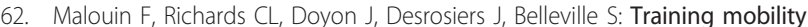
tasks after stroke with combined mental and physical practice: a feasibility study. Neurorehabil Neural Repair 2004, 18(2):66-75.

63. Malouin F, Richards $C L$, Durand A, Descent M, Poire D, Fremont P, Pelet $S$, Gresset J, Doyon J: Effects of practice, visual loss, limb amputation, and disuse on motor imagery vividness. Neurorehabil Neural Repair 2009, 23(5):449-463

64. Page SJ, Levine $P$, Sisto $S$, Johnston MV: A randomized efficacy and feasibility study of imagery in acute stroke. Clin Rehabil 2001, 15(3):233-240.

65. Page SJ, Levine P, Sisto SA, Johnston MV: Mental practice combined with physical practice for upper-limb motor deficit in subacute stroke. Phys Ther 2001, 81(8):1455-1462

66. Stenekes MW, Geertzen JH, Nicolai JPA, De Jong BM, Mulder T: Motor imagery for peripheral injury response. Arch Phys Med Rehabil 2009, 90(8):1443-1444.

67. Martin KA, Hall CR: Using mental imagery to enhance intrinsic motivation. J Sport Exerc Psych 1995, 17(1):54-69.

68. Munroe JO, Chandler $\mathrm{KJ}$ : The effects of image speed on the performance of a soccer task. Sport Psychol 2008, 22(1):1-17.

69. Reiser M: Strength gains by motor imagery of maximal muscle contractions. Z Sportpsychol 2005, 11-21.

70. Ryan ED, Simons J: Cognitive demand, imagery, and frequency of mental rehearsal as factors influencing acquistion of motor skills. J Sport Psychol 1981, 3:35-45

71. Smith D, Collins D: Mental practice, motor performance, and the late CNV. J Sport Exerc Psych 2004, 26(3):412-426.
72. Smith $D$, Holmes $P$, Whitemore $L$, Collins $D$, Devonport $T$ : The effect of theoretically-based imagery scripts on field hockey performance. J Sport Behav 2001, 24(4):408-419.

73. Toussaint $L$, Blandin $Y$ : On the role of imagery modalities on motor learning. J Sport Sci 2010, 28(5):497-504

74. Wakefield CJ, Smith D: Impact of differing frequencies of PETTLEP imagery on netball shooting performance. J Imagery Res Sport Phys Act 2009, 4(1), ArtID 7

75. White KD, Ashton R, Lewis S: Learning a complex skill: Effects of mental practice, physical practice, and imagery ability. Int J Sport Psychol 1979, 10(2):71-78.

76. Williams JG, Odley $\mathrm{J}$, Callaghan M: Motor imagery boosts proprioceptive neuromuscular facilitation in the attainment and retention of range of motion at the hip joint. J Sport Sci Med 2004, 3(3):160-166.

77. Wright CJ, Smith D: The effect of PETTLEP imagery on strength performance. J Sport Exerc Psych 2009, 18-31.

78. Yaguez L, Nagel D, Hoffman H, Canavan AGM, Wist E, Homberg V: A mental route to motor learning: Improving trajectorial kinematics through imagery training. Behav Brain Res 1998, 90(1):95-106.

79. Robin N, Dominique L, Toussaint L, Blandin Y, Guillot A, Le Her M: Effects of motor imagery training in service return accuracy in tennis: the role of imagery ability. Int J Sport Exerc Psychol 2007, 5(2):175-186.

80. Smith D, Wright C, Allsopp A, Westhead H: It's All in the Mind: PETTLEPBased Imagery and Sports Performance. J App/ Sport Psychol 2007, 19(1):80-92.

81. Smith D, Wright CJ, Cantwell C: Beating the Bunker: The effect of PETTLEP imagery on golf bunker shot performance. Res Q Exerc Sport 2008, 79(3):385-391

82. Smith GG, Morey J, Tjoe E: Feature Masking in Computer Game Promotes Visual Imagery. Journal of Educational Computing Research 2007, 36(3):351-372

83. Rodrigues EC, Lemos T, Gouvea B, Volchan E, Imbiriba LA, Vargas CD: Kinesthetic motor imagery modulates body sway. Neuroscience 2010, 169(2):743-750.

84. Bovend'Eerdt TJH, Dawes H, Sackley C, Izadi H, Wade DT: Mental techniques during manual stretching in spasticity - a pilot randomized controlled trial. Clin Rehabil 2009, 23(2):137-145.

85. Doheny MO: Effects of mental practice on performance of a psychomotor skill. J Ment Imagery 1993, 17:111-118.

86. Moseley GL, Zalucki N, Birklein F, Marinus J, van Hilten JJ, Luomajoki H: Thinking about movement hurts: The effect of motor imagery on pain and swelling in people with chronic arm pain. Arthrit rheumat 2008, 59(5):623-631.

87. Start KB: Intelligence and the improvement in a gross motor skill after mental practice. Brit J Educ Psychol 1964, 34(1):85-90.

88. Start KB, Richardson A: Imagery and mental practice. Brit J Educ Psycho 1964, 34(3):280-284

89. Braun S, Beurskens AJ, Kleynen M, Oudelaar B, Schols JM, Wade DT: Effects of mental practice in stroke rehabilitation in Dutch nursing homes: results of a randomised controlled trial. 2010

90. Braun S, Beurskens AJ, Kleynen M, Schols JM, Wade DT: Effects of mental practice in patients with Parkinson's disease: results from a multi-centre randomised controlled trial. 2010.

91. Morin L, Latham GP: The effect of mental practice and goal setting as a transfer of training intervention on supervisors' self-efficacy and communication skills: An exploratory study. Appl Psychol Int Rev 2000, 49(3):566-578

92. Rodgers KC: Directed imagery versus free imagery for inducing changes in self-perspective and mood. Dis Abstr Int 1982, 42(7-B):3001.

93. Bucher $L$ : The effects of imagery abilities and mental rehearsal on learning a nursing skill. J Nurs Edu 1993, 32(7):318-324.

94. Doheny MO: Effects of mental practice on psychomotor skills with baccalaureate nursing students. Dis Abstr Int 1990, 51(2-B):659.

95. Immenroth $M$, Eberspacher $H$, Nagelschmidt M, Troidl H, Burger T, Brenner J, Berg T, Muller M, Kemmler R: Mental training in surgery Security by a better training: Design and first results of a study. MIC 2005, 14(1):69-74.

96. Komesu Y, UrwitzLane R, Ozel B, Lukban J, Kahn M, Muir T, Fenner D, Rogers R: Does mental imagery prior to cystoscopy make a difference? A randomized controlled trial. Am J Obstet Gynecol 2009, 201(2):218. e211-218.e219. 
97. Sanders CW, Sadoski M, Bramson R, Wiprud R, Van Walsum K: Comparing the effects of physical practice and mental imagery rehearsal on learning basic surgical skills by medical students. Am J Obstet Gynecol 2004, 191(5):1811-1814

98. Sanders CW, Sadoski M, van Walsum K, Bramson R, Wiprud R, Fossum TW: Learning basic surgical skills with mental imagery: using the simulation centre in the mind. Med Educ 2008, 42(6):607-612.

99. Stig LC, Christensen HW, Byfield D, Sasnow M: Comparison of the effectiveness of physical practice and mental practice in the learning of chiropractic adjustive skills. Eur J Chiropractic 1989, 37(3):70-76.

100. Welk A, Immenroth M, Sakic P, Bernhardt O, Eberspächer H, Meyer G: Mental training in dentistry. Quintessence Int 2007, 38(6):489-497.

101. Cramer SC, Orr ELR, Cohen MJ, Lacourse MG: Effects of motor imagery training after chronic, complete spinal cord injury. Exp Brain Res 2007, 177(2):233-242.

102. Crosbie JH, McDonough SM, Gilmore DH, Wiggam Ml: The adjunctive role of mental practice in the rehabilitation of the upper limb after hemiplegic stroke: a pilot study. Clin Rehabil 2004, 18(1):60-68

103. Dijkerman HC, letswaart M, Johnston M, MacWalter RS: Does motor imagery training improve hand function in chronic stroke patients? A pilot study. Clin Rehabil 2004, 18(5):538-549.

104. Dunsky A, Dickstein R, Ariav C, Deutsch J, Marcovitz E: Motor imagery practice in gait rehabilitation of chronic post-stroke hemiparesis: fou case studies. Int J Rehabil Res 2006, 29(4):351-356.

105. Dunsky A, Dickstein R, Marcovitz E, Levy S, Deutsch J: Home-based motor imagery training for gait rehabilitation of people with chronic poststroke hemiparesis. Arch Phys Med Rehabil 2008, 89(8):1580-1588,

106. Gustin SM, Wrigley PJ, Gandevia SC, Middleton JW, Henderson LA, Siddall PJ: Movement imagery increases pain in people with neuropathic pain following complete thoracic spinal cord injury. Pain 2008, 137(2):237-244.

107. Hewett TE, Ford KR, Levine P, Page SJ: Reaching kinematics to measure motor changes after mental practice in stroke. Top Stroke Rehabil 2007, 14(4):23-29.

108. Jackson PL, Doyon J, Richards CL, Malouin F: The efficacy of combined physical and mental practice in the learning of a foot-sequence task after stroke: a case report. Neurorehabil Neural Repair 2004, 18(2):106-111.

109. Liu KP, Chan CC, Lee TM, HuiChan CW: Mental imagery for promoting relearning for people after stroke: A randomized controlled trial. Arch Phys Med Rehabil 2004, 85(9):1403-1408.

110. Liu KP, Chan CC, Lee TM, Hui-Chan CW: Mental imagery for relearning of people after brain injury. Brain Inj 2004, 18(11):1163-1172.

111. Liu KPY, Chan CCH, Wong RSM, Kwan IWL, Yau CSF, Li LSW, Lee TMC: A randomized controlled trial of mental imagery augment generalization of learning in acute poststroke patients. Stroke 2009, 40(6):2222-2225.

112. McCarthy M, Beaumont JG, Thompson R, Pringle $\mathrm{H}$ : The role of imagery in the rehabilitation of neglect in severely disabled brain-injured adults. Arch Clin Neuropsych 2002, 17(5):407-422.

113. Moseley GL: Graded motor imagery is effective for long-standing complex regional pain syndrome: a randomised controlled trial. Pain 2004, 108(1-2):192-198.

114. Moseley GL: Is successful rehabilitation of complex regional pain syndrome due to sustained attention to the affected limb? A randomised clinical trial. PPA News 2005, 114(1-2):54-61.

115. Mueller K, Butefisch CM, Seitz RJ, Homberg V: Mental practice improves hand function after hemiparetic stroke. Restor Neurol Neurosci 2007, 25(56):501-511.

116. Page SJ: Imagery improves upper extremity motor function in chronic stroke patients: a pilot study. Occup Ther J Res 2000, 20(3):200-215.

117. Page SJ, Levine P, Leonard AC: Effects of mental practice on affected limb use and function in chronic stroke. Arch Phys Med Rehabil 2005, 86(3):399-402

118. Page SJ, Levine $P$, Hill V: Mental practice as a gateway to modified constraint-induced movement therapy: A promising combination to improve function. Am J Occup Ther 2007, 61(3):321-327.

119. Page SJ, Levine $P$, Leonard A: Mental practice in chronic stroke: Results of a randomized, placebo-controlled trial. Stroke 2007, 38(4):1293-1297.

120. Page SJ, Szaflarski JP, Eliassen JC, Pan H, Cramer SC: Cortical plasticity following motor skill learning during mental practice in stroke. Neurorehabil Neural Repair 2009, 23(4):382-388.
121. Page SJ, Levine $P$, Khoury JC: Modified constraint-induced therapy combined with mental practice thinking through better motor outcomes. Stroke 2009, 40(2):551-554.

122. Riccio I, Iolascon G, Barillari MR, Gimigliano R, Gimigliano F: Mental practice is effective in upper limb recovery after stroke: A randomized singleblind cross-over study. Eur J Rehabil Med 2010, 46(1):19-25.

123. Simmons L, Sharma N, Baron JC, Pomeroy VM: Motor imagery to enhance recovery after subcortical stroke: who might benefit, daily dose, and potential effects. Neurorehabil Neural Repair 2008 , 22(5):458-467.

124. Stevens JA, Stoykov ME: Using motor imagery in the rehabilitation of hemiparesis. Arch Phys Med Rehabil 2003, 84(7):1090-1092.

125. Tamir R, Dickstein R, Huberman M: Integration of motor imagery and physical practice in group treatment applied to subjects with Parkinson's disease. Neurorehabil Neural Repair 2007, 21(1):68-75.

126. Yoo E, Chung B: The effect of visual feedback plus mental practice on symmetrical weight-bearing training in people with hemiparesis. Clin Rehabil 2006, 20(5):388-397, (334 ref) NLI: 8802181.

127. Coffman DD: Effects of mental practice, physical practice, and knowledge of results on piano performance. J Res Music Educ 1990, 38(3):187-196

128. Ross SL: The effectiveness of mental practice in improving the performance of college trombonists. J Res Music Educ 1985, 33(4):221-230.

129. Rubin Rabson G: Studies in the psychology of memorizing piano music. Vl: A comparison of two forms of mental rehearsal and keyboard overlearning. J Educ Psychol 1941, 32(8):593-602

130. Sonnenschein I: Mentales Training in der Instrumentenausbildung (MTI). Psychol Erz Unterr 1990, 37(3):232-236.

131. Theiler AM, Lippman LG: Effects of mental practice and modeling on guitar and vocal performance. J Gen Psychol 1995, 122(4):329-343.

132. Allami N, Paulignan Y, Brovelli A, Boussaoud D: Visuo-motor learning with combination of different rates of motor imagery and physical practice. Exp Brain Res 2008, 184(1):105-113.

133. Alves J, Belga P, Brito AP: Mental Training and Motor Learning in Volleyball. Prague: European Federation of Sport Psychology 1999, 59-61.

134. Andre JC, Means JR: Rate of imagery in mental practice: An experimental investigation. J Sport Psychol 1986, 8(2):124-128.

135. Chevalier N, Boucher JP, Geoffrion R, Denis M: Visual and kinesthetic imagery in the mental rehearsal of a complex movement: an exploratory study. Sports science: 8 Commonwealth and international conference on sport, physical education, dance, recreation and health: 1986; Glasgow 1986, 343-348.

136. Clark LV: Effect of mental practice on the development of a certain motor skill. Res Q Am Ass Health, Phys Ed Recr 1960, 31:560-569.

137. Clegg BA, Wood JA, Bugg JM: Real and imagined movements in older and younger adults. J Ment Imagery 2004, 28(1-2):1-16.

138. Corbin CB: Effects of mental practice on the development of a specific motor skill. PhD thesis. Eugene, Ore.; United States: University of New Mexico; 1966.

139. Cornwall MW, Bruscato MP, Barry S: The effect of mental practice on isometric muscular strength. J Orthop Sport Phys 1991, 13:231-234.

140. Decety J: Motor information may be important for updating the cognitive processes involved in mental imagery of movement. Cur Psychol Cogn 1991, 11(4):415-426.

141. Gassner K, Einsiedel T, Linke M, Grlich P, Mayer J: Does mental training improve learning to walk with a femoral prosthesis? Orthopade 2007, 36(7):673-678

142. Gordon S, Weinberg R, Jackson A: Effect of internal and external imagery on cricket performance. J Sport Behav 1994, 17:60-76.

143. Gray SW: Effect of visuomotor rehearsal with videotaped modeling on racquetball performance of beginning players. Percept Motor Skills 1990, 70(2):379-385

144. Hellwing W, Knuff W: Mental preparation: a possibility for intensifying physical education. Sportunterricht 1976, 25(6):180-187

145. Hemayattalab R, Movahedi A: Effects of different variations of mental and physical practice on sport skill learning in adolescents with mental retardation. Res Dev Disabil 2009, 31(1):81-86.

146. Herrero JA, Garcia D, Soria E: Influence of imagery rehearsal on the maximum isometric force in bench press. Policlinico Sez Med 2004 111(1):11-20. 
147. Jaehme W, Steinhoefer D: Empirical study on the effectiveness of mental training in swimming with 10th and 11th grade high school students. Lehrhilf Sportunterr 1978, 27(5):71-74.

148. Jones JG: Motor learning without demonstration of physical practice, under two conditions of mental practice. Res Quart 1965, 36(3):270-276.

149. Kelsey IB: Effects of mental practice and physical practice upon muscular endurance. Res Quat 1961, 32:47-54.

150. Kohl RM, Roenker DL: Bilateral transfer as a function of mental imagery. $J$ Motor Behav 1980, 12(3):197-206.

151. Kornspan AS, Overby L, Lerner BS: Analysis and performance ofpreperformance imagery and other strategies on a golf putting task. J Ment Imagery 2004, 28:59-74.

152. Kremer P, Spittle M, McNeil D, Shinners C: Amount of mental practice and performance of a simple motor task. Percept Motor Skills 2009, 109(2):347-356.

153. Krigolson O, Van Gyn G, Tremblay L, Heath M: Is There "Feedback" During Visual Imagery? Evidence From a Specificity of Practice Paradigm. Can J Exp Psychol 2006, 60(1):24-32

154. Linden CA, Uhley JE, Smith D, Bush MA: The effects of mental practice on walking balance in an elderly population. Occup Ther J Res 1989, 9(3):155-169.

155. Maring JR: Effects of mental practice on rate of skill acquisition. Phys Ther 1990, 70(3):165-172.

156. McAleney PJ, Barabasz AF, Barabasz M: Effects of flotation restricted environmental stimulation on intercollegiate tennis performance. Percept Motor Skills 1990, 71(3):1023-1028.

157. Minas SC: Mental practice of a complex perceptual-motor skill. J Hum Movement Stud 1978, 4(2):102-107.

158. Papaxanthis C, Pozzo T, Skoura X, Schieppati M: Does order and timing in performance of imagined and actual movements affect the motor imagery process? The duration of walking and writing task. Behav Brain Res 2002, 134(1-2):209-215.

159. Phipps SJ, Morehouse CA: Effects of mental practice on the acquisition of motor skills of varied difficulty. Res Q Exericse Sport 1969, 40(4):773-778.

160. Ranganathan VK, Siemionow V, Liu JZ, Sahgal V, Yue GH: From mental power to muscle power-gaining strength by using the mind Neuropsychologia 2004, 42(7):944-956.

161. Rawlings El, Rawlings IL, Chen SS, Yilk MD: The facilitating effects of mental rehearsal in the acquisition of rotary pursuit tracking. Psychon Sci 1972, 26(2):71-73.

162. Ryan ED, Simons J: Cognitive demand, imagery, and frequency of mental rehearsal as factors influencing acquisition of motor skills. J Sport Psychol 1981, 3(1):35-45

163. Ryan ED, Simons J: Efficacy of mental imagery in enhancing mental rehearsal of motor skills. J Sport Psychol 1982, 4(1):41-51.

164. Shackell EM, Standing LG: Mind Over Matter: Mental Training Increases Physical Strength. N Am J Psychol 2007, 9(1):189-200.

165. Sidaway S, Trzaska A: Can mental practice increase ankle dorsiflexor torque? Phys Ther 2005, 85(10):1053-1060.

166. Singer RN, Witker J: Mental rehearsal and point of introduction within the context of overt practice. Percept Motor Skills 1970, 31(1):169-170.

167. Smith LE, Harrison JS: Comparison of the effects of visual, motor, mental, and guided practice upon speed and accuracy of performing a simple eye-hand coordination task. Res Q Am Assoc Health, Phys Ed Recr 1962, 33(2):299-307

168. Smyth MM: The role of mental practice in skill acquisition. J Motor Behav 1975, 7(3):199-206

169. Start KB: Relationship between intelligence and the effect of mental practice on the performance of a motor skill. Res Q Am Assoc Health, Phys Ed Recr 1960, 31:644-649.

170. Start KB: Kinaesthesis and mental practice. Res Q Am Assoc Health, Phys Ed Recr 1964, 35(3):316-320.

171. Stebbins RJ: A comparison of the effects of physical and mental practice in learning a motor skill. Res Quart 1968, 39(3):714-720.

172. Surburg PR: Aging and effect of physical-mental practice upon acquisition and retention of a motor skill. J Gerontol 1976, 31(1):64-67.

173. Tunney N, Billings K, Blakely BG, Burch D, Jackson K: Mental practice and motor learning of a functional motor task in older adults: a pilot study. Phys Occup Ther Geriatr 2006, 24(3):63-80.

174. Twining WE: Mental practice and physical practice in learning a motor skill. Res Q Am Assoc Health, Phys Ed Recr 1949, 20:432-435.
175. Van Gyn G, Wenger HA, Gaul C: Imagery as a method of enhancing trenasfer from training to performance. J Sport Exerc Psychol 1990, , 12: 366-375.

176. Vandell RA, Davis RA, Clugston HA: The function of mental practice in the acquisition of motor skills. J Gen Psychol 1943, 29:243-250.

177. Whiteley G: Effect of mental rehearsal in association with physical practice in the acquisitions of simple gymnastic techniques. Research papers in physical education 1966, 3(Dec):25-28.

178. Wohldmann EL, Healy AF, Bourne LE: Pushing the Limits of Imagination: Mental Practice for Learning Sequences. J Exp Psychol Learn Mem Cogn 2007, 33(1):254-261.

179. Woolfolk RL, Murphy SM, Gottesfeld D, Aitken D: Effects of mental rehearsal of task motor activity and mental depiction of task outcome on motor skill performance. J Sport Psychol 1985, 7(2):191-197.

180. Woolfolk RL, Parrish MW, Murphy SM: The effects of positive and negative imagery on motor skill performance. Cognitive Ther Res 1985, 9(3):335-341.

181. Zecker SG: Mental practice and knowledge of results in the learning of a perceptual motor skill. J Sport Psychol 1982, 4(1):52-63.

182. Casby A, Moran A: Exploring mental imagery in swimmers: A single-case study design. Irish J Psychol 1998, 19(4):525-531.

183. Guillot A, Nadrowska E, Collet C: Using Motor Imagery to Learn Tactical Movements in Basketball. J Sport Behav 2009, 32(2):189.

184. Olsson CJ, Jonsson B, Nyberg L: Internal imagery training in active high jumpers. Scand J Psychol 2008, Apr 2008.

185. Shambrook CJ, Bull SJ: The use of a single-case research design to investigate the efficacy of imagery training. J Appl Sport Psychol 1996, 8(1):27-43.

186. Ziemainz $\mathrm{H}$, Stoll O, Kuster C, Adler K: Evaluation of the mental training of the change from one event to the other in youth and junior triathlon. Leistungssport 2003, 33(2):20-22.

\section{Pre-publication history}

The pre-publication history for this paper can be accessed here:

http://www.biomedcentral.com/1741-7015/9/75/prepub

doi:10.1186/1741-7015-9-75

Cite this article as: Schuster et al:: Best practice for motor imagery: a systematic literature review on motor imagery training elements in five different disciplines. BMC Medicine 2011 9:75.

\section{Submit your next manuscript to BioMed Central and take full advantage of:}

- Convenient online submission

- Thorough peer review

- No space constraints or color figure charges

- Immediate publication on acceptance

- Inclusion in PubMed, CAS, Scopus and Google Scholar

- Research which is freely available for redistribution

Submit your manuscript at www.biomedcentral.com/submit
C Biomed Central 